

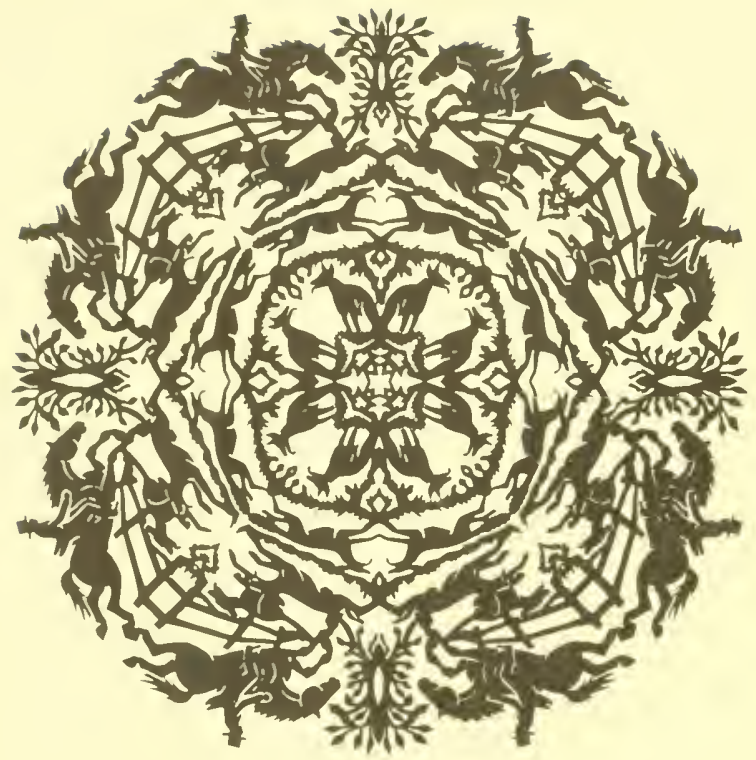

JOHN A.SEAVERNS 
A GREAT YEAR 




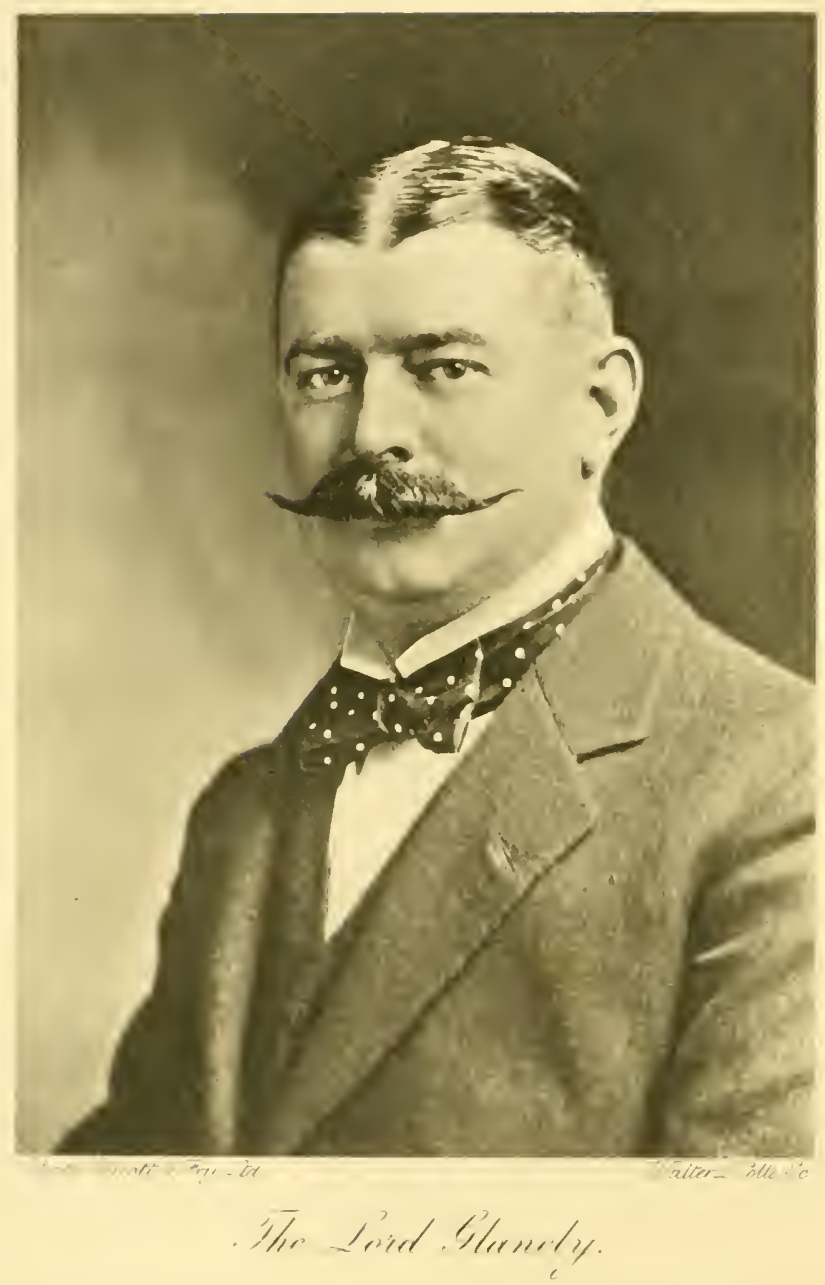




\title{
A GREAT YEAR
}

\section{LORD GLANELY'S HORSES}

\author{
BY \\ ALFRED E. T. WATSON \\ Assistant Editor of and Contributor to 'The Badminton Library' \\ Sectional Editor, 'Encyclopadia Britannica' \\ Author of 'Sketches in the Hunting Field,' 'Racecourse and Covertside,' 'Racing and \\ 'Chasing,' 'The Racing World and its Inhabitants,' 'King Edward VII. as a \\ Sportsman,' 'A Sporting and Dramatic Career' (Reminiscences), etc. \\ For private circulation, 'Lord Derby's Racehorses,' 'Galicia : Her Forbears and \\ her Offspring,' 'Prince Palatine: His Pedigree and Performances' \\ 'Green: Yellow Sleeves'
}

WITH ILLUSTRATIONS

PRINTED FOR PRIVATE CIRCULATION BY

LONGMANS, GREEN A N CO.

39 PATERNOSTER ROW, LONDON

FOURTH AVENUE \& 30TH STREET, NEW YORK

BOMBAY, CALCUTTA, AND MADRAS

I 92 I 



\section{CONTENTS}

CHAPTER I

"The Head of the List" . . . . . . I

CHAPTER II

The Gradual Rise - $\quad$ - $\quad$ - $\quad$ - 30

CHÄPTER III

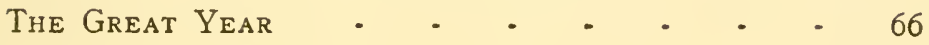

CHAPTER IV

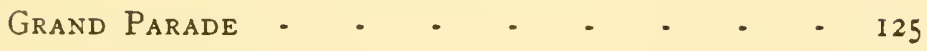

CHAPTER V.

He, Sky-Rocket, and Treclare - • • - 173

CHAPTER VI

Danebury and the Mares - $\quad$ - $\quad$ - $\quad$ - 199

POSTSCRIPT

Westward Ho! and Blue Exign • • • • 215 



\section{LIST OF ILLUSTRATIONS}

\section{PHOTOGRAVURE PLATES}

Portrait-The Lord Glanely - - - - Frontispiece From a photograph by Elliott \& Fry Ltd.

Leading in Grand Parade at Epsom - - $\quad 86$ From a photograph by W.A. Rouch.

The Seven Ascot Winners - - $\quad$ - $\quad$ - 95 From photographs by Clarence Hailey, Newmarket.

Grand Parade, Winner of the Derby, i9i9 - - 125 From photograph by Clarence Hailey, Newmarket.

Grand Parade at Exning Stud - - - $\quad$ - 157 From a photograph by Clarence Hailey, Newmarket.

He at Danebury Stud - $\quad$ - $\quad$ - $\quad$ - 173 From a photograph by W. A. Rouch.

Skyrocket at Danebury Stud - - - - $\quad$ - 180 From a pholograph by W. A. Rouch.

Treclare at ExNing Stud- - - - - - 193 From a photograph by Clarence Hailey, Newmarket.

HALF-TONE PLATES

Exning House, Newmarket - - - - . 2

Quantock as a Two-year Old • - $\quad$ - $\quad$ - 33 
Grand Fleet

QueEn Empress $\}$

PACING PAGB

Scatwell - $\quad \cdot \quad \cdot \quad \cdot \quad \cdot \quad \cdot \quad \cdot \quad \cdot 52$

Dominion as a Three-year Old - - - $\quad$ - 59

Grand Parade winning the Derby, 1919 - $\quad 85$

Bright Folly (Two-years Old)
Starshot

Grand Fleet $\quad \cdot \quad \cdot \quad \cdot \quad \cdot \quad \cdot \quad \cdot \quad \cdot \quad \cdot$ II

$\left.\begin{array}{l}\text { The Midshipmite } \\ \text { Mares and Foals at Danebury }\end{array}\right\}$ • • • • • II3

$\left.\begin{array}{l}\text { Lord Glanely's Training Stables, Newmarket } \\ \text { Stallion Boxes, Exning }\end{array}\right\} \cdot 128$

Lord Glanely's Training Establishment and Paddocks, NewMarket

The Grange Stud Farm Paddocks, Newmarket

White Horse Paddock, Exing

Stallion Paddocks, Exning

Lackham House, Lacock - • • • - - 166

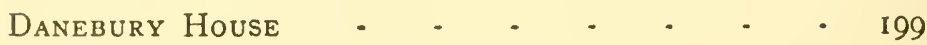

Danebury as SEen from the Downs- • - - $20 \mathrm{I}$

The Grange Stud Farm, Newmarket - • - 2 I2

Westward Ho! as Yearling at Doncaster • • 215 


\title{
A GREAT YEAR
}

\author{
CHAPTER I \\ "THE HEAD OF THE LIST"
}

IN the year I 919 no fewer than 55 I owners of horses shared in the distribution of a sum of $£ .588,587$ I 5 s.it is as well to be strictly accurate, so the shillings are not omitted, and it may be incidentally noted that one of the richest prizes ever won on the Turf, the Lancashire Plate at Manchester in I89I, secured by the Chevalier Ginistrelli's Signorina, amounted to the remarkable sum of $f_{1} 10,222$ Ios. Iod. In the total mentioned for I 919 as many as forty-five owners barely contrived to qualify for a place by winning a single event worth the minimum permissible under Jockey Club Rules, £ioo. Of the remainder, nineteen owners were credited with prizes of not less than 65000. At the head of the list came Lord Glanely with $£_{30}, 654$ Ios., a total which it may be remarked does not include place money; and it has seemed to me that it would be interesting to compile a record 
of the forty-five victories by which the total was gained: because this, with comment on the subjects to which it leads, would in a great measure serve as a history of the Turf during the period under discussion.

Lord Glanely not only obtained his position at the head of the list, but did so handsomely by a margin of 6775I. It appears specially appropriate that the owner who attains supremacy should include the Derby among his year's spoils, and this was the case in I9 19, the Blue Riband being won by a colt, Grand Parade, whose merit for reasons presently to be set forth has certainly been underrated, though, as it happens, Lord Glanely did not owe his lead to the successes of a single horse as has almost invariably been the case with those who have accumulated most money. Little races, medium sized and big ones, make up the total we are about to investigate, and it includes what so far as I remember or have been able to ascertain has never been accomplished before, the taking of precisely a quarter of the stakes in the Ascot Programme. That alone makes the year memorable for the owner who achieved it. At the Royal Meeting during the four afternoons twenty-eight races are invariably run, and the owner of the black jacket, red, white and blue belt, won seven of them.

It may be well to take a glance at those who have been at the head of the list for, let us say, the last quarter of a century, and one detail to be noted is the very 


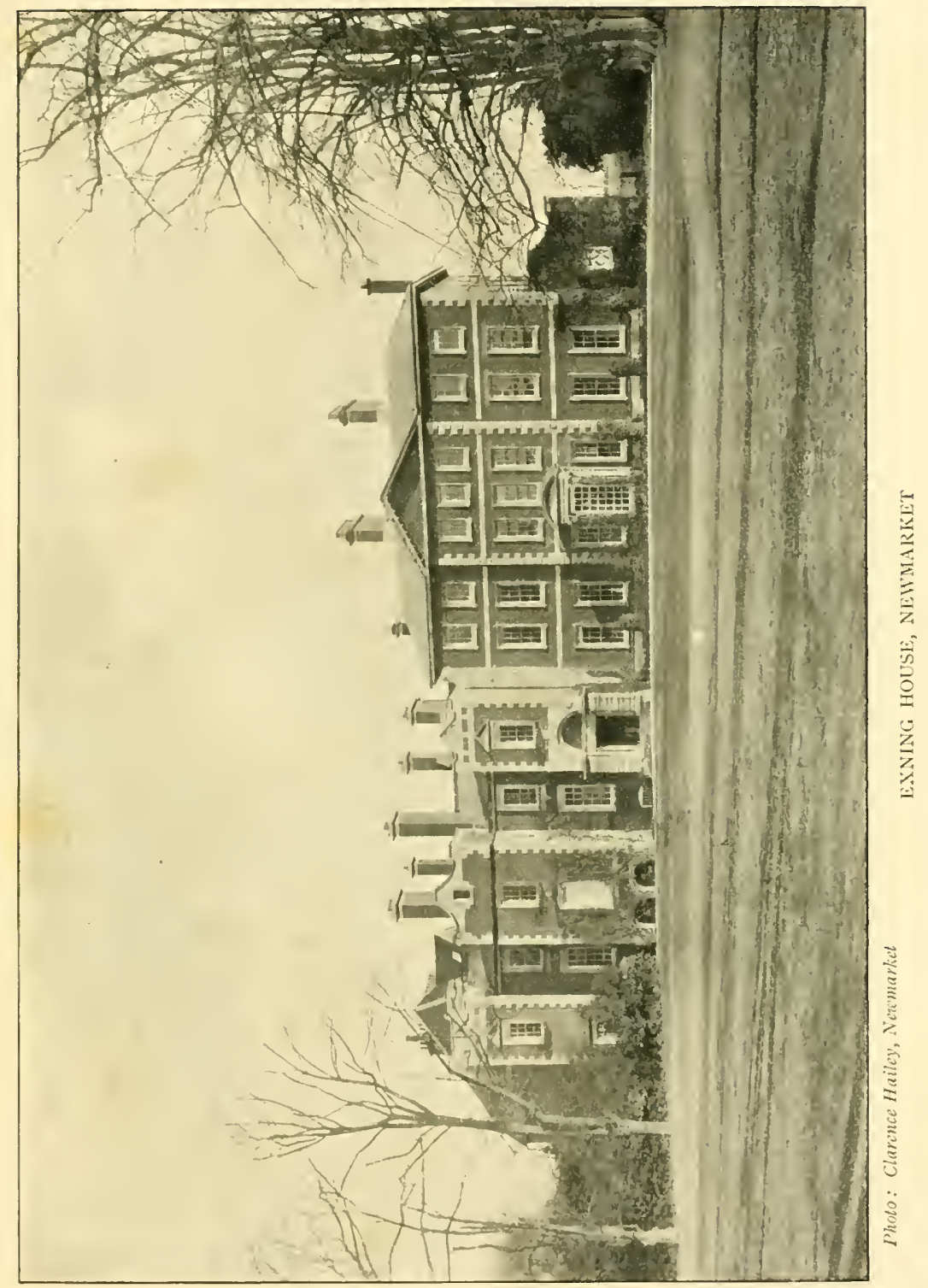



varying sums which have placed them there. Going back a little further than the period mentioned we find the Duke of Portland with figures which have never been approached and are never likely to be. In 1889 the array of huge stakes was altogether unprecedented, and the Duke secured the lion's share, winning in all $673,85^{8}$ ios. And yet it would be protested by some people that during the season he had some strokes of very bad luck. There can be no doubt that Donovan ought to have beaten Mr. Douglas Baird's Enthusiast for the Two Thousand Guineas, and that without trouble. The victory of the son of Sterling was a triumph of jockeyship, explained to me by the superb horseman who accomplished the feat, Tom Cannon. He deprived the Duke of 64000 - the prize was small that season, it has since been over twice as muchwith which he should beyond question have been credited. F. Barrett, a successful jockey who not seldom held his own among the best, rode Donovan. Watts, who it may be observed was one of Tom Cannon's pupils, was on Pioneer, the property of that extraordinary character "Mr. Abington." What was thought of the prospects of the race appeared from the betting, 85 to 20 on Donovan, 100 to 8 against Pioneer, 25 to I bar two. "The other two had a couple of little races all to themselves some distance from home," so said Tom Cannon, with a twinkle in his eye, in answer to my question how he had contrived 
to do it, "so when they started on a third I thought I might as well join in!"

Sir George Chetwynd worked out the form and pronounced it to be just $2 \mathrm{I} \mathrm{lb}$. wrong. The truth was that Watts and Fred Barrett were in too great a hurry to get home, and by judiciously waiting with Enthusiast, Mr. Douglas Baird's colt was able to beat one who was vastly his superior. In the nineties waiting races were discredited. We were told that the only correct method of race riding was to "come through." Thus Sloan, undoubtedly a genius, gained many of his successes. In truth he often waited, though he did so in front, and when he and his imitators had passed away, Maher and F. Wootton, one or other of whom headed the list of winning jockeys year after year for a good many seasons-as a rule a long way before the nearest of their followers-went back to the tactics which had for generations been found to answer. Because a horse is beaten a head it by no means follows that his owner has had bad luck, as is so frequently assumed, and the question whether the Duke was unlucky in having an inferior jockey on his good colt raises a point which need not be argued.

Donovan, who prior to the Two Thousand had won the Princess of Wales's Stakes at Leicester, worth fI I ,, 00 , proceeded to win the Newmarket Stakes from another colt belonging to the Duke, named The Turcophone, an event then worth $£ 6000$, Enthusiast 
unplaced. Donovan won the Derby, of the small value that year of $f_{4} 050$, Enthusiast again nowhere. At Ascot the Prince of Wales's Stakes of $£ 2225$ went to swell Donovan's total, as did the Leger, worth £4800, Enthusiast fourth, behind Miguel and Davenport ; also the Lancashire Plate, Mr. Charles Perkins' Chittabob second, and the good French filly Alicante, then a two-year-old, third. Here Enthusiast was nowhere once more. This Manchester race was worth EIO, I 3 I I 5s., and the Royal Stakes at the Newmarket Second October swelled the aggregate by the comparative trifle of $£ 460$, making Donovan's earnings for the year in all $£ 38,666$ i 5 s. Ayrshire only won twice in three attempts, but these races were the Kempton Park Royal Stakes of $£ 9500$, and the Eclipse, which that year yielded $f_{\mathrm{I}} \mathrm{I}, \mathrm{I} 65$. The Duke's two-year-old Semolina started for fifteen races that season and won twelve of them. Memoir, the own sister to La Flèche, though relatively a vast deal better as a three-yearold, in her first season won thrice. It was indeed an amazing year.

Starting with the period suggested for examination, I 895, Mr. Leopold de Rothschild led the way, as he was destined to do twice subsequently, thrice in four years. As usual it was one horse, and-what is not so usual-that a two-year-old, to whom he mainly owed his position. This was St. Frusquin, the son of St. Simon and Isabel, the dam a mare who did much 
for the success of the Rothschild stud. There were several rich two-year-old prizes at that period which no longer exist. St. Frusquin won the Royal Stakes of $£ 3155$ at Kempton, but in the Imperial Produce Plate failed by half a length to give $12 \mathrm{lb}$. to a colt named Teufel, a result the more unexpected because the stable in which the winner was trained was remarkable for winning a number of small stakes but seldom sheltered a good horse. St. Frusquin proceeded to win the Sandringham Gold Cup at Sandown, then a race for two-year-olds, the Chesterfield, the Middle Park, and the Dewhurst; together with $f 450$ for his second at Kempton he earned in all $£_{1} 0,072$ of the $\oint_{20,749-a}$ total below the average. Utica, another characteristically Rothschild bred, a daughter of St. Simon and Biserta, produced within a few sovereigns of $£ 2000$.

In 1896 St. Frusquin was a still more copious contributor. As most people, even those outside the racing world, are aware, the Prince of Wales's Persimmon beat Mr. Leopold de Rothschild's colt in the Derby by a neck. Without in any way depreciating the bearer of the Royal colours it must nevertheless be admitted that it is a question whether the powerful John Watts on Persimmon had not a marked advantage over the little short-legged T. Loates, who at the time could go to scale at $7 \mathrm{st} .5 \mathrm{lb}$. ? It may be urged that $T$. Loates won a very large number of races, that in 
the year of which we are speaking he was second in the table of winning jockeys, with I 56 victorious mounts, eight fewer than Mornington Cannon who came first. T. Loates was a jockey whose services, it need hardly be said, owners were keen to secure whatever weight their horses might have; but St. Frusquin wanted getting out, so did Persimmon, and Watts in consequence of his strength was better able to give his colt the necessary help. For the rest St. Frusquin ran four races and won them all. The Column Produce Stakes was only worth $£ 778$, nor was it a rich Two Thousand, as it amounted that season to no more than $\$ 4250$-in I 920 Craig an Earn credited Lord Astor with $£ 8200$-but the Prince of Wales's Stakes in which Persimmon, trying to give 3 lb., was beaten half-a-length, totalled $£ 9005$ and the Eclipse 69305 . T. Loates rode St. Frusquin in his victorious Newmarket race, Watts being again, of course, on Persimmon; but I do not admit that this vitiates my argument, which is broadly that a 9 st. man, or a man close on that weight, given equal skill, has an advantage over a little jockey who weighs something like a couple of stone less. On the book Persimmon and St. Frusquin come out as nearly as possible the same horse.

There is no doubt that St. Frusquin might readily have added within a few pounds of another $£ 3000$ to the $f_{2} 3,33^{8}$ which his four races produced, according 
to my figures. In those days I was in the habit of riding out on the Heath in the morning and generally came across St. Frusquin's owner similarly employed. I did so on the morning of the Newmarket Stakes day. Mr. Leopold de Rothschild was never disinclined to talk about his horses and their prospects, indeed he liked to do so, and was always generously pleased when he could tell his friends he thought that bearers of the dark blue, yellow cap, were worth backing. I remember making the remark that I supposed St. Frusquin would win the principal event of the afternoon, and was told that he would not run. The going was very hard, the colt not the soundest of horses, and his owner said that he fancied Galeazzo would be equal to the occasion, thus sparing St. Frusquin's legs. The Newmarket Stakes was not regarded as a good thing for this son of Galopin and Eira. He, the Duke of Westminster's Labrador, and Duke of Devonshire's Balsamo, were as nearly as possible equal favourites. Galeazzo won from Balsamo by a neck, Loates again beating Watts.

In 1896 the head of the list figures were more than double those of 1895 , amounting to $£ 46,763$. A two-year-old filly helped towards this to the extent of £.448 I, viz. Goletta, half-sister to Utica by Galopin, and about her there was a curious circumstance. $\mathrm{Mr}$. Leopold de Rothschild told me he had no sort of doubt that Mr. "Fairie's" Eager was distinctly better than 
his filly, nevertheless the two met on three occasions and each time the filly beat the colt. She did so by two lengths in the Coventry Stakes at Ascot, by a head in the Chesterfield, by a head again in the Rous Memorial at the Newmarket First October Meeting. How she came to do it her owner declared himself not able to understand, and it could not have been jockeyship, for Eager was ridden by Mornington Cannon, who had no superior.

The year I 897 was made striking by the fact that Mr. J. Gubbins, who headed the list with $£ 22,739$, owed it all except the trifle of $\mathrm{KO}_{2}$ to one horseGaltee More, the son of Kendal and Morganette. The previous season Lord Rosebery's Velasquez had been looked on as the best of the two-year-olds prior to the Middle Park Plate, when with odds of 5 to $I$ on Velasquez Galtee More beat him in a canter by half a dozen lengths. The result was too hastily asserted to be altogether wrong, for as three-year-olds Galtee More gave the most convincing evidence that such a supposition was a mistake. Mr. Gubbins' colt won the Two Thousand Guineas of $£ 3700$, the Newmarket Stakes of $£ 2945$, the Derby of $£ 5450$, the Prince of Wales's Stakes at Ascot at $f_{1775}$, the Sandringham Cup at Sandown, then a three-year-old race, of $f_{1} \mathrm{I} 300$, the Leger of $£ 5425$, and the Sandown Foal Plate of $£ 2042$, that is, in all $£ 22,637$. He failed only once. After such a season it was perhaps not very kind to 
ask the colt to run in a handicap with the weight which must inevitably be allotted to him. He started for the Cambridgeshire, however, burdened with 9 st. $6 \mathrm{lb}$. and it cannot be thought strange that he was beaten.

In 1898 again Mr. Leopold de Rothschild came to the front. He ran an extraordinary number of horses, a considerable number of whom won nothing, but those who did score took fifty-three races in all, worth $£ 30,267$ ios. St. Frusquin had gone. He could never be brought out again after the Eclipse, and so a race which had been looked forward to with peculiar interest, the Leger, which would have enabled him to decide the question with Persimmon, lost the attraction it had promised to produce; for it was evident that nothing could beat the Prince's colt, on whom odds of I I to 2 were laid. Goletta had trained on, and became the principal scorer, for after winning a Triennial at Ascot worth $£ 682$, she contributed $£ 850$ I by her victory in the Princess of Wales's Stakes. St. Gris, a son of Galopin and Isabel-thus more than half-brother to St. Frusquin, St. Gris being by St. Frusquin's sire Galopin and having the same damgreatly distinguished himself by beating Flying Fox for the Imperial Produce Stakes at Kempton Park. Another smart two-year-old named Trident won three good races. Jacquemart won the Hunt Cup, $£ 2340$, and other races. A colt named Fosco earned half a 
dozen brackets, indeed Mr. Leopold de Rothschild had a thoroughly satisfactory year.

Flying Fox had failed twice as a two-year-old, for besides his defeat by St. Gris, Caiman beat him for the Middle Park Plate; but he made no sort of mistake and in 1899 placed his owner, the Duke of Westminster, at the head of the list. The son of Orme and Vampire led off with the Two Thousand Guineas, $£ 4250$, after which came the Derby, $£ 5450$, the Princess of Wales's Stakes, $£_{7} 190$, the Eclipse, $£ 9285$, the Leger, $£ 4040$ and the Jockey Club Stakes, $£ 7$ I 90 , a total of $£ 37,405$. There can be no doubt that much of his success was due to his jockey, Mornington Cannon, for, as John Porter remarks in his autobiography, as soon as the colt reached Kingsclere he was "inclined to be somewhat mulish, and," John Porter continues, "I have always thought it was just as well he left the Turf at the end of his threeyear-old days, for had he remained in training a third season he would I am convinced have caused us a lot of trouble. He had undoubtedly inherited some of his dam's wilful temperament. As a set off against this the sire and dam had transferred to the colt their strong constitution, for Flying Fox was one of the toughest horses I ever had under my care." John Porter goes on to record that "At Doncaster Flying Fox was in an excited mood. Morny Cannon had to dismount at the starting post and soothe him by 
feeding him with tufts of grass," a spectacle which many of us well recall, and naturally it created no small apprehension on the part of those who had laid long odds. In this year a three-year-old of the Duke's named Frontier won the Ascot Derby : the remaining $£ 5000$, for the Duke's total was $£ 43,965$, was made up in nine races, the whole number he won having been only sixteen.

The year 1900 was a peculiarly gratifying one for the reason that his Royal Highness the Prince of Wales made his way to the top, almost entirely by the aid of Persimmon's younger brother Diamond Jubilee. What rendered this the more satisfactory was that as a twoyear-old the son of St. Simon and Perdita II. had been a very doubtful quantity. Favourite for the Coventry Stakes at a shade over even money he had finished unplaced. Favourite again for the July Stakes he had behaved like a mad horse at the post, took no part in the race, which was won by Captain Kettle, the outsider of the party, belonging to a relation of my own who had not the least expectation of success. Diamond Jubilee did better at Goodwood, though he did not win there, his first success being in the Boscawen Stakes, where he beat a filly called Paigle, belonging to Captain Kettle's owner, by a short head. This was, indeed, his only win as a two-year-old, for Democrat beat him in the Middle Park Plate, as he did again in the Dewhurst. As a three-year-old the colt sobered 
down and had a brilliant career. He came out for the Two Thousand Guineas, in which there were two better favourites, and won by four lengths from a 50 to I outsider in Bonarosa. He won the Newmarket Stakes, though only by a head, from Chevening, and then created a scene of the wildest excitement by winning the Derby from the Duke of Westminster's Simon Dale and the American colt Disguise II. ridden by Sloan.

In the Princess of Wales's Stakes he failed to give $20 \mathrm{lb}$. to the present Lord Wavertree's Merry Gal, but was to the fore again in the Eclipse, Chevening again second, in receipt however of Io lb., Simon Dale unplaced. He won the Leger with odds of 7 to 2 on him, and failed for the second time during the season in the Jockey Club Stakes, starting favourite, but running indifferently. The Prince's total was $£ 29,585$, of which Diamond Jubilee made $£ 27,985$. H.R.H. had nothing else of note, and as mentioned only won four other races.

In I90I Sir J. Blundell Maple, one of the most considerable owners of the period, came to the front with $£ 21,370$, after a close fight with the American, Mr. W. C. Whitney, who got as far as £r 9,720 Ios., and Mr. Kincaid with $\ell_{18,953}$. It was not a good year, that is to say the class was not high. To me Common, who won Two Thousand, Derby and Leger, not having run as a two-year-old, always rather 
suggested his name. Macintosh was the chief scorer for Sir John, The Bishop and Royal Lancer yielding their quota, and his colours were successfully carried by Lord Bobs, Aquascutum, Champagne, Cossack, Avidity, Simony, Royal Majesty and Royal Summons, the last named a daughter of Siffleuse, who created a sensation in 1893 by winning the One Thousand, starting at 33 to $\mathrm{I}$, the race being esteemed something like a certainty for her owner's Dame President, a redhot favourite.

During I 901 much interest had attached to Sceptre, for though she only won a couple of races, starting thrice, it was realised that she was in all probability destined to do great things. Such an impression did she create by her victory in the Woodcote Stakes that when she came out for the July Stakes odds of Io to I were laid on her, and she handsomely fulfilled anticipation the following season. With a little luck she would have created what in all probability must have remained a record for all time-have won all the five classic races; as it was she took four of them. Her reappearance was made in the Two Thousand Guineas, which she won without difficulty, as she did the One Thousand. For a long time after her failure in the Derby, for which she was no nearer than fourth to Ard Patrick, it was protested by her admirers that she certainly ought to have won. This became much less evident, in fact was contradicted, when Ard Patrick 
the following season beat her for the Eclipse Stakes at Sandown. She won the Oaks, however, and going to Ascot took the St. James's Palace Stakes. It was thought worth while to send her to Goodwood, where she ran twice, and she ended the year by easily carrying off the Leger, her five races adding up to $£ 23,195$, which enabled $\mathrm{Mr}$. Sievier to come out at the head of the list, his total being $£^{2} 3,686$. There was one curious thing about Sceptre. She was beaten in the Derby and at the same meeting won the Oaks. She failed in the Coronation Stakes at Ascot and promptly made up for it by taking the St. James's Palace Stakes. Similarly at Goodwood, after losing the Sussex Stakes on Wednesday she took the Nassau on Friday. Sceptre is now the property of Lord Glanely, and her last offspring, Queen Empress, has a colt foal by He.

In 1903 Sir James Miller's Rock Sand enabled his owner to lead the way. This was surely one of the luckiest colts, that is to say the colt's owner was one of the luckiest of men; for Rock Sand, though his winnings were so huge, rather had the way cleared for him in valuable stakes, and when he met Sceptre and Ard Patrick they had no difficulty in reducing him to his level. Rock Sand, a son of Sainfoin and Roquebrune, had only failed once in his seven attempts as a two-year-old, when third to Flotsam and Greatorex for the Middle Park Plate, and as I have been speaking critically of him, it is only fair to say that he beat 
Greatorex by more than three lengths in the Dewhurst. As a three-year-old he first ran in the Bennington Stakes at the Craven Meeting, a race which those who saw it will not forget, as it was run in a blizzard of snow, which rendered the colours well-nigh if not actually indistinguishable to occupants of the Private Stand. His other outings were in the Two Thousand, the Derby, the St. James's Palace Stakes and the Leger, which meant an accumulation of $\oint_{1} 8,425$ of the $£ 24,768$ which Sir James totalled, nearly $£ 2000$ of the balance coming from Rondeau, whilst Pharisee won the Durdans Plate, worth nearly another $\oint_{1}$ ooo. Rock Sand did even better as a four-year-old than he had done as a three. He started with a failure, being beaten for the Coronation Cup at Epsom by Zinfandel and Sceptre. This was his only defeat, and he went on to win the Hardwicke Stakes at Ascot, $£ 2404$, the Princess of Wales's Stakes, $£_{7185}$, the Lingfield Park Plate, $£_{2} 420$, the First Foal Stakes at the Newmarket Second. July, £275, and the Jockey Club Stakes, 67435, making in all $£$ I9,719. Pharisee was not idle and helped towards the $£_{27,928}$, as did Amitié, a filly in whom Sir James was particularly interested, as she was a daughter of Chaleureux, with whom he won the Cesarewitch, and of La Sagesse, with whom he won the Oaks. It need hardly be said that there is something specially gratifying in the victory of homebred horses. 
In 1905 the then Colonel W. Hall Walker, now Lord Wavertree, gained some reward, a handsome one indeed, for his sedulous devotion to the Turf. The union of Isinglass and Black Cherry had resulted in a filly called Cherry Lass, who ran well as a twoyear-old, winning three of the six races she contested, but unlike so many of her sex trained on and was considerably better as a three. She carried off the One Thousand, the Oaks, the St. James's Palace Stakes, a race which has to be mentioned so often, the Duchess of York Stakes at Hurst Park, the Nassau and the Newmarket Oaks. Her owner has always been absolutely convinced that she ought certainly to have won the Leger, for which she started at odds of 6 to 4 on, evidence that other people accepted his estimate of her. The danger was supposed to be Llangibby, who however strained or sprained himself by his antics while being saddled-I was at another part of the paddock and did not watch the process-the result of the race being that Mr. Washington Singer's Challacombe, starting at 100 to 6 , won by three lengths from Polymelus, with Cherry Lass third. I remember a friend of $\mathrm{Mr}$. Singer chaffingly remarking that Challacombe's owner ought to have put on a tall hat in order that he might look more effective as he led in the winner, never of course supposing that such a duty was in the least likely to devolve upon him. 
Cherry Lass's half dozen victories yielded $£_{\text {I } 3}$, I I 9 , the best scorer after her being a colt called Black Arrow, a son of Count Schomberg-a remarkable horse, for he was good alike at practically all distances on the flat, over hurdles and over fences-and Black Cherry, half-brother therefore to Cherry Lass. I think Colonel Hall Walker regarded him as the best he had ever bred. His merit was known before he first came out for the Newmarket Two-Year-Old Plate at the First Spring Meeting. Odds were laid on him in a field of eighteen, and jumping off he was never approached, winning by half a dozen lengths. It was by the same distance with odds of 9 to 2 on him that he won the Coventry Stakes at Ascot, and having only a couple of indifferent animals to beat for the Lavant Stakes at Goodwood the race was naturally considered a foregone conclusion. The ring began by offering to take 100 to 3 , but Black Arrow gave a violent exhibition of misbehaviour at the post, and when the flag fell was hopelessly left, taking no part in the race. He did something to retrieve the mishap the following month, readily winning the Champion Breeders' Foal Stakes at Derby ; but that was his last success, and when he died a postmortem revealed a physical condition which seemed to render it amazing he could ever have won a race at all.

The year 1906 saw Lord Derby in the place of 18 
honour, and that with the largest total achieved for several seasons past. Towards the $£ 32,926$ I 5 s. Bridge of Canny, a son of Love Wisely and Santa Brigida, did most. The colt had indeed a very busy season, for he came out fifteen times in all, starting at Liverpool the opening week and continuing until the end of October. He lost the Union Jack Stakes at Liverpool by half a length to Beppo, but just got home by a head for the Kingsclere Stakes at Newbury, oddly enough from another son of his sire; and he proceeded to win a Biennial at Ascot, the First Foal Stakes at the Newmarket Second July, the Knowsley Dinner Stakes, the Durham County Produce Stakes, the Great Yorkshire Stakes, the Great Foal Stakes at the Newmarket Second October, a Triennial, and finally the Gatwick Stakes, worth that season $£ 3742, £ 10,255$ I 5 s. in all. That good mare Keystone II. did still better as an earner of stakes. She led off with the Oaks, £4950, at Ascot took the Coronation, $£_{2} 800$, at Sandown the Three-Year-Old Produce Stakes, £4357, and at Liverpool the St. Leger and Duchy Plate, in all fir 2,837 .

Nothing has ever been much more obvious in racing than that she ought to have won the Doncaster Leger. This was not Maher's lucky race. On at least two occasions here, as at Epsom on Llangwm, he rode the best horse and the best horse was beaten; but it happened that the fact was plainly demonstrated in the case of 
Keystone. Maher appeared to get muddled up with her at the turn into the straight. She lost her place and never recovered it, though only beaten three heads, Troutbeck winning by the narrowest of margins from Prince William, Beppo no further away third, Keystone II. next. In the Jockey Club Stakes she gave Beppo I $2 \mathrm{lb}$. and ran him to a length. Allowing $3 \mathrm{lb}$. for the beating, which is sufficiently liberal considering that the distance is a mile and three-quarters, this makes her $9 \mathrm{lb}$. the better of the two; moreover in the Sandown Three-Year-Old Produce Stakes, meeting Prince William on even terms instead of receiving $3 \mathrm{lb}$. from him as at Doncaster, she beat him five and a half lengths.

Lord Derby had a number of other winners, the Eugenia filly, Pleiades II., Victorious, Glucose, Gourd, Glastonbury, Yellow Peril, Vedas, Chaucer, who won the Liverpool Cup, Venilia, Olympian, etc.

It has been noted that very varying sums have placed owners at the head of the list, but except during the war the first place had not for many years been gained by so little as the $£ 17,910$ ros. which was sufficient for the present Lord Wavertree in 1907. This was almost entirely secured by three horses, Witch Elm, a daughter of Orme and Cannie Lassie, took the One Thousand; Polar Star, who if not absolutely the best of his season as a two-year-old was probably second to none, won the Jubilee and another little race; 
whilst White Eagle carried off the first four of his five races, the Woodcote, a Triennial at Ascot, the Fulbourne and the National Breeders' Produce Stakes, worth $£ 4357$. Much was hoped of a son of Ladas and Pintail, called Indian Runner, and not without reason, for though he only won a single race in five attempts, the Mersey Stakes at Liverpool, he was second on three other occasions, beaten-a headby Dibbs for a Triennial at Ascot, then by Norman III., who was to win the Two Thousand next season, and by the speedy Tiptoe II. in the Wynyard Plate at Stockton.

In I $908 \mathrm{Mr}$. J. B. Joel's turn came. He headed the list with $£ 26,246$, and as it will be seen has usually happened the great bulk was taken by one horse, Your Majesty, a son of Persimmon and Yours. As a two-year-old Your Majesty had not done much. He won the Boscawen by a neck, but was beaten in his four other attempts, only once making his way into a place; but as a three-year-old his four victories were substantial ones. For the Two Thousand Guineas he cannot have been at all fancied, as odds of 20 to I were offered against him, the favourite that season being King Edward's disappointing colt Perrier, backed at 5 to 4 . Your Majesty did not run for the Derby, as will have been gathered, but is one of the number mentioned who has taken the St. James's Palace Stakes at Ascot. His next outing was in the Eclipse, 
\$8870. He won the St. George Stakes at Liverpool, his fifth and last race of the season being the Leger. The four successes yielded $\ell_{19} 9,286$, and Dean Swift once more did his share. The son of Childwick repeated his victory of two years before in the City and Suburban, won the Liverpool Cup, the Southdown Plate at Lewes and appeared to exceptional advantage in the Select Stakes at the Newmarket Second October. Lord Derby's Cocksure II. had done brilliantly, winning four races off the reel, and at Newmarket, in what had become a match, odds of 85 to 40 were laid on him, Maher in the saddle; but Walter Griggs on Dean Swift beat the three-year-old a head, and that it meant much was demonstrated in the Cambridgeshire, where Cocksure II., a three-year-old burdened with 8 st. 5 lb., was close up, fourth, to Marcovil, Land League and Succour, Lord Derby's colt starting favourite at 3 to I. Portland Bay won the Wokingham, as also the May Handicap at Gatwick.

Mr. "Fairie," as my old friend Mr. A. W. Cox was called until close upon the end of his career when he reverted to his own name, came to the front in 1909 , when first place meant the acquisition of $£ 37,719$; and yet he esteemed himself not a little unfortunate because Bayardo did not win the Derby. That he ought to have done so seems to have been demonstrated by what happened in the Leger, and there was to all appearance a good reason for the Epsom 
failure. The American colt Sir Martin, as many readers of these pages will remember, fell in the course of the race, and the precise effect which the accident had upon the field can never be exactly known. As a two-year-old Bayardo had never been beaten, coming out seven times for stakes which count, varying in amount as they did from $£ 65^{2}$ to $£ 4357$. I think it may be assumed that he was not ready in the Two Thousand, but after the Derby he went to the post eleven times with unbroken success. $\mathrm{He}$ won the Prince of Wales's Stakes at Ascot, the Sandringham Foal Stakes, the Eclipse, the Duchess of York Stakes, the Leger, the Doncaster Stakes, the Champion Stakes, the Lowther Stakes, the Sandown Foal Stakes, the Limekiln Stakes and the Liverpool St. Leger, his season's work producing $£ 24,797$.

His half-brother Lemberg helped substantially: as Bayardo had done and as so many horses before him, Lemberg came out in the New Stakes at Ascot. He won the Chesterfield, the Rous Memorial at Goodwood and the race of the same name at Newmarket, the Middle Park Plate and the Dewhurst, $£ 9360$ in all, so that the half-brothers between them earned that year $\{34,157$, and both moreover kept it up the following season. Bayardo's reappearance in I910 was made in the Newmarket Biennial. He went to Chester to bring back the Vase, to Ascot for the Gold Cup, which he won in the most brilliant style-as 
described in a volume I wrote for my old friend entitled Galicia, her Forbears and her Offspring. But Bayardo's last appearance was a melancholy one, for he suffered what may almost be described as an incredible defeat. This was for the Goodwood Cup. His old jockey Maher, who knew him so well, was in the saddle, and bookmakers offered to take 20 to I. Twenties were freely on offer against Mr. H. E. Beddington's three-year-old Magic, the other runner being a creature called Bud who was altogether out of place in such a contest. I remember Mr. Beddington telling me that he fancied he had an outside chance, but Magic had done nothing which seemed to justify such an opinion and moreover did nothing subsequently, though on the strength of this Goodwood Cup he was heavily backed on more than one occasion. It appears extraordinary that the colt's only success was when he beat Bayardo, who had naturally seemed invincible, but so it was. Magic had a neck the better of it. After the race some of the critics thought they remembered that Bayardo had not been looking well, but I did not ascertain that this had occurred to anybody before he went to the post. His yield as a four-year-old was $£ 6698$ Ios., his younger brother therefore overshadowing him, for the seven races secured by the three-year-old brought in $f_{2}^{2} 3,839$.

There was a great struggle for the Two Thousand Guineas between Lemberg and Lord Rosebery's Neil 
Gow. They had met the previous season in the Champagne Stakes at Doncaster, where Neil Gow inflicted on the other his first and only defeat, and Neil Gow was preferred for the classic, starting at 2 to 1 , whilst 7 to 2 could be had about Lemberg. Until the number was hoisted no one could tell what had happened, the general impression being that the two had run a dead heat. The Judge announced that Neil Gow had won a head, which he specially described as short. Afterwards Lemberg ran in eight races and won six of them outright, dead-heating for the seventh. His victories were the Derby, the St. James's Palace Stakes at Ascot once more, and then for the Eclipse the accuracy of the Two Thousand form was practically made manifest, the Judge being unable to separate the two. Subsequently, however, Lemberg took the Jockey Club Stakes of $\$ 7440$, the Champion, the Lowther, and the Sandown Foal Stakes. In the books of reference, it may be added, Lemberg's winnings as a three-year-old are given at $£ 28,224$, but it will be understood that this is because the whole $£ 8770$ of the Eclipse is reckoned instead of the $£ 43^{8} 5$ his owner actually received.

To the day of his death Mr. Fairie was convinced that Maher by riding a bad race lost the Leger, which was won by Lord Derby's Swynford, Lemberg third a head behind Bronzino, whom he surely ought to have beaten. Mr. Fairie was by no means demonstrative, 
but he could not hide his vexation. He always occupied a box at Doncaster in which he entertained his friends at lunch. I happened to be alone with him after the race. He gazed across the course and murmured, "And I give that jockey $£ 2000$ a year to ride for me!" I was half inclined to reply, "If you had not done so you would have been $£ 8000$ in pocket," but it was not the time for such a comment.

In I 9 I I Lord Derby had a great year, coming first with a substantial balance of $£ 42,72 \mathrm{I}$, two bearers of the black jacket, white cap standing out. It would perhaps be guessed offhand that Swynford, the famous son of John o' Gaunt and Canterbury Pilgrim, did most, but as a matter of fact Stedfast earned more money for the stable. The son of Chaucer and $\mathrm{Be}$ Sure started with the Prince of Wales's Stakes at Ascot, $\ell_{1725}$, and then took the St. James's Palace, exactly $£_{1700}$. Going on to his owner's home meeting, Stedfast won the Atlantic Stakes, £igra, and at Goodwood the Sussex Stakes, f637. The Great Yorkshire Stakes produced fir 33 , and he walked over for the Doncaster Stakes, £495. His richest prize was the Jockey Club Stakes, $£_{784} \mathrm{I}$, and he wound up the season brilliantly by beating Prince Palatine for the Kingsclere Stakes at Newbury, earning in all $f_{1} 6,079$. Swynford won the Chippenham Plate, the Hardwicke, the Princess of Wales's Stakes, $£ 3265$ and the Eclipse, $£ 8735$, in all $£ 14,904$. 
The form with Lemberg, it may be remarked, was somewhat varied. He beat Mr. Fairie's colt, who was however giving him 5 lb., in the Princess of Wales's Stakes, beat him at even weights in the Eclipse, Lemberg having previously beaten Lord Derby's colt at evens in the Coronation Cup. King William was a winner, but at the same time a disappointment. Both he and Swynford went for the Princess of Wales's Stakes, and both were backed. I recollect next day meeting Lord Derby at St. Pancras station on the way to Newmarket, and remarking that I had expected to see King William in front of his stable companion, notwithstanding that the young one started at 9 to 2, Swynford at 3 to I ; and Lord Derby replied that the gallop prior to the race had given the idea that the young one was the better. The Ascot Derby was King William's chief win. It brought in $£ 3297$; and Hair Trigger II. also did well, though she missed the Oaks, this having been the year when Mr. Brodrick Cloete's Cherimoya won that classic on the occasion of her only appearance on the racecourse. Hair Trigger II. however earned $£_{4} 659$, these four having therefore produced $£ .38,949$ of the $£ 43,72 \mathrm{I}$.

The story of 1912 is soon told. Prince Palatine carried off the Gold Cup, the Eclipse, the Doncaster Cup and the Jockey Club Stakes, adding up to $£_{1} 8,830$ of the $£ 20,822$ which put Mr. Thomas Pilkington at the head, and it has always seemed an extraordinary 
thing that the colt should have been beaten for the Prince of Wales's Stakes, for which he started a hot favourite at 5 to 2 on.

Jest, the chestnut daughter of Sundridge and Absurdity, gave Mr. J. B. Joel a lead, by winning the One Thousand Guineas, $£ 6400$, and the Oaks, 6.4950, which rendered it impossible to catch him in I 9 I 3. He wound up with $£_{2} 5$, I I 5 , and the following season Black Jester, Jest's half-brother by Polymelus, won five races worth $f_{1} 0,988$, including the Leger, whilst Princess Dorrie secured the One Thousand Guineas and the Oaks, both of which that season were worth $£ 4950$. This brought in over $£ 20,000$ of the f.30,986 to which the seasons gains amounted.

Sir Edward Hulton accumulated in I9I 6 a total of $\{3,746$. In an ordinary year winning the Derby and Oaks would, of course, have produced a highly satisfactory total. The substitute classics which Fifinella, the daughter of Polymelus and Silver Fowl, took in I 9 I 6 meant only $£ 4000$. Margarethal won a couple of good stakes, the First Spring and the Buckenham, which together yielded $£ .3147$, and amongst other contributors was Knutsford, a son of Swynford and Maybole, who won thrice in a manner which caused him to be placed at the head of the Free Handicap. So far from continuing his successes Knutsford proved a complete failure, and as a threeyear-old never even ran into a place. 
In 1917 the late Mr. Fairie came first with the poor yield of $£_{1} I, 75$ I, of which $\oint_{10}$ I 80 came from Gay Crusader, whose successes included the Two Thousand Guineas, the Derby, the September Stakes, rated as the substitute Leger, the Newmarket Gold Cup, the Champion, Lowther and Limekiln Stakes; and another son of Bayardo, Gainsborough, did most to secure supremacy for Lady James Douglas in I918. Gainsborough won half a dozen races valued at $£$ I $3,4 \mathrm{IO}$. In several events he and his stable companion, Gay Crusader, were both engaged, and the owner of the latter expressed to me a keen desire to meet the younger colt, having an agreeable conviction that Gay Crusader was considerably the better of the two. Lady James's total was $f_{1} 4,735$. This brings us to the Great Year, a description of which is the object of the present volume. 


\section{CHAPTER II}

THE GRADUAL RISE

Lord Glanely's rise to the head of the list was a gradual but not unchecked ascent from the humblest beginning. With wise discretion he had determined not to indulge in ownership on an elaborate scale until experience enabled him clearly to understand what he was doing. In the year $1908 \mathrm{Mr}$. Walter Raphael owned a very moderate three-year-old named Goémon, a son of Merman, the Cesarewitch and Ascot Cup winner, and Tutti Frutti. Goémon was a winner on rare occasions of minor races. He had the luck to come upon three others worse than himself in a First Foal Stakes at the Newmarket Second July, and though this was the only race he secured that season Mr. W. J. Tatem, as Lord Glanely then was, took a mild fancy to the colt and bought it. He first carried his new owner's colours, then dark blue, white yoke, sleeves and cap, in the Prince of Wales's Stakes on the first day of the Epsom Meeting in 1909, unmentioned in the betting and unplaced in the race. He did no better in the Earlsfield Welter at Hurst Park, but at 
Lingfield in June he got home by a head from $\mathrm{Mr}$. J. L. Dugdale's Jack's Folly in the Ford Manor Plate. This was the owner's first win, as small a one as the Rules of Racing admitted, for the stake was only $\oint_{\mathrm{i}} \mathrm{oo}$. There is, however, always a special interest attaching to a first victory.

A second for the Brighton Highweight Handicap to Colonel Michael Hughes' Southannan was the best Goémon could do in six subsequent attempts, and Mr. Tatem's name appeared in the list of winning owners with the bare $f_{1} 00$ to his credit; for though he had two other runners neither won anything. The pair were Glen Clova, a daughter of Forfarshire and Miss Lettice, a mare who now ranks as a dam of winners, and St. Vitus, a son of Colonel Harry McCalmont's good horse St. Maclou and Vetch. It has always seemed strange that St. Maclou had not more success at the stud than fell to his lot. Of his capacity as a racehorse there could be no doubt. He won the Lincolnshire Handicap with 7 st. I $2 \mathrm{lb}$, giving Sceptre within a pound of weight for age, was beaten a neck for the Cambridgeshire, giving Ballantrae 3I lb., and won the Manchester November Handicap with 9 st. 4 lb. Lord Glanely's horses, it should be added, were trained by W. R. Baker at Collingbourne.

All the three mentioned won races, that is to say each won a race, the following season. Glen Clova's 
first essay was in a Maiden Plate at Lingfield, and proved a miss, but she rather unexpectedly won the Romney Welter at the Folkstone Summer Meeting. Goémon had a busy season, for he started the first week at Liverpool in the Earl of Sefton's Plate, and going to the post thirteen times in all was out the last week, the very last day indeed, for the Farewell Handicap at Manchester. His eleventh race resulted in a win, the Worcester Autumn Handicap, and he only lost the London and Brighton Handicap at Lingfield by a short head. St. Vitus ceased to be a maiden after being second in a mildly sensational race at Sandown. Here Lord Derby's Royal Escort bolted and got rid of his rider, F. Wootton, to be captured and remounted, however, and in spite of his wild gallop he won from Lord Glanely's colt. St. Vitus carried off the July Welter at the Bibury Club Meeting from joint favourites, Mr. George Edwardes's Matelot and Mr. R. P. Cobbold's Catchpenny. The yield of the season was the moderate sum of $£ 325$.

In I9 I there was a marked improvement. St. Vitus led off with a win. His appearance was delayed until late in autumn, when he secured the Doddington Welter Handicap at Bath, and he won the Avon Plate at Birmingham, a good favourite. A gelding called La $\mathrm{La}$, his name derived from sire and dam, Ladas and $\mathrm{La}$ Carolina, attracted Lord Glanely sufficiently to induce him to give 220 guineas for him after he had won a 


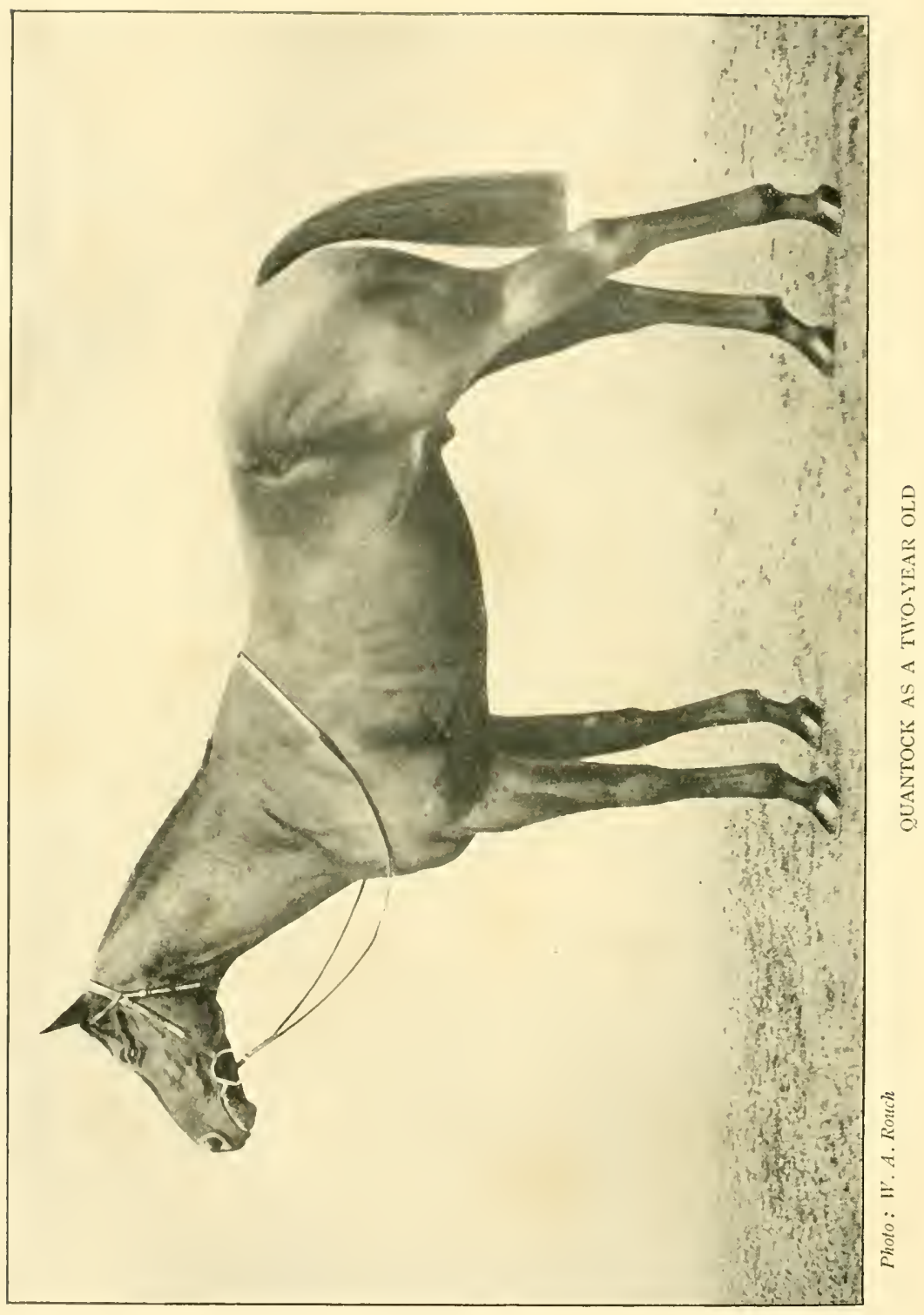


Selling Plate at Birmingham, and he won him a similar event at Wolverhampton. But Lord Glanely was by this time the owner of a notably speedy colt to carry the revised colours, which were now black, red, white and blue belt and cap. This was a son of Thrush and Rock Egg, later to earn reputation as Quantock. The unnamed-he ran as the Rock Egg colt-came out for the Sefton Park Plate at the Liverpool Spring, and, not mentioned in the betting, won it from Sir Robert Jardine's daughter of Desmond and Sapphic. Quantock was distinctly the best animal Mr. Tatem had secured so far. He ran well for the Spring Two-YearOld Stakes at Kempton, His Majesty's Carol Singer, who was to have such a long career on the flat and over hurdles, beating him a head for second place behind Mr. L. Neumann's Astra; and that the colt was highly esteemed is shown by the fact that it was thought worth while to let him start for the Fern Hill Stakes at Ascot. Sir William Cooke's Hornet's Beauty, invincible just then-he won all the fifteen races in which he took part that year-was one of the runners, and it is not surprising that the two-year-old, useful as he was, could make no impression on the flying son of Tredennis.

The Packington Plate at Warwick the Rock Egg colt won in a canter by four lengths, but His Majesty's Mirabeau with an advantage in the weights beat him and the rest for the Highclere Nursery at Newbury. 
Lord Glanely was, however, to wind up with a handsome victory. In the $\oint_{1} 1000$ Chesterfield Nursery at Derby Mr. C. S. Newton's Cap and Gown was made a warm favourite at 9 to 4 , a natural result of his previous performances, Captain Harry Greer's Bangalore and the Rock Egg colt were next in demand at 6 to I, and the last named got home, if with nothing to spare, from Lord Londonderry's smart Pitmaston, who was in receipt of $4 \mathrm{lb}$. Quantock was well redeeming his promise. Other runners were Coedkernew, a son of Melayr or St. Gris out of Draconic, and Greenmeadow, a son of Bushey Park and Lavenne. They failed to score. The season, with six races won by three horses, yielded $f_{1} 92 \mathrm{I}$.

It will be considered strange that Quantock should have won nothing as a three-year-old. Still the five races in which he took part were by no means easy ones to win. F. Wootton was engaged to ride him in the Esher Cup, in which Cap and Gown failed by a short head to give I $3 \mathrm{lb}$. to Mr. Gamburg's Le Touquet, Quantock unplaced. In the Empire Stakes at Newbury he started at 7 to 2, second favourite to Mr. A. B. Stern's very useful horse Cigar at 5 to 2, but again finished unplaced, as he did to a younger half-sister of Glen Clova, Captain J. Orr-Ewing's daughter of St. Amant and Miss Lettice, afterwards known as Amulet, for the Fern Hill Stakes, which he thus attempted a second time. The Champion Sprint 
Handicap at Hurst Park always brings out horses of exceptional speed, and did so as usual in I9I2. Mr. C. E. Hay's Questa II. came first in the market at 4 to I, followed by Quantock, and the then Colonel E. W. Baird's Orsova at I I to 2. Quantock beat everything except Mr. L. Winans's Minehead, who had three-quarters of a length the better of the finish, Mr. J. R. Keene's very fast colt Castleton-who is running still, or was so within a few months of the time of writing - third, in front of Mr. H. P. Whitney's Iron Mask II. and Matinée, Sir William Nelson's Duke of Padua and Captain N. Alfrey's Hallaton, a remarkable animal, for prior to being put into training and holding his own in the very best company he had done duty as a hack and hunter. There are other instances of what may be called equine angels entertained unawares. An animal called Betelgeux used to be ridden with a pack of harriers kept by Tom Cannon at Danebury, and no one thought of him as a winner of races. Observing his speed, however, he was put into training and beat animals, fairly useful, who had won races elsewhere, at five furlongs. I remember a farmer looking at Betelgeux in the paddock after he had won a race at Stockbridge and observing, "No wonder my old cob couldn't keep up with that one!"

It was little discredit to Quantock to have failed here, probably too he was not at his best that autumn, 
for he made no show in the Croxteth Cup at the Liverpool Autumn Meeting. Lord Glanely's horses, however, won half a dozen races, as they had done the previous season, though there was no $£ 900$ Plate like the Chesterfield Nursery. Coedkernew took the Doddington Welter at Bath, before being sent to Austria, Greenmeadow the Coventry Plate at Worcester, St. Vitus the Ford Manor Handicap, Sir Josh a son of Sir Joshua and Morskaya, bought out of a selling race at Gatwick in June for 360 guineas, next ran for the Belvoir Castle Stakes at Leicester and won from Mr. L. Winans's Dainty Prince. A two-yearold daughter of Duke of Westminster and Spirited, Dancing Mistress by name, won the Doddington Selling Plate at Birmingham and was allowed to go to Mr. George Edwardes; also a son of Eager and Star of the Sea called Starboard Light won the County Two-Year-Old Plate at Bath. There were others this season who ran unsuccessfully.

Hitherto it will have been perceived Lord Glanely had not chosen to spend much money on his purchases. At Doncaster the previous season, however, he had paid 2 roo guineas for a son of Polymelus and Indian Ink, called Indian Mail. Polymelus was just beginning to make his reputation at the stud, the name, by the way, being Lord Crewe's own invention, as I remember gathering from him in the course of a journey to a meeting where the horse won a race 
before his breeder parted with him. The combination of Cyllene and Maid Marian suggested nothing and a name had to be devised. I think this was really not a bad one, its want of meaning notwithstanding, for if no one ever was called Polymelus someone well might have been! In his first season Indian Mail came out five times without earning brackets, always in good company, however, leading off with a Triennial at Ascot and following on with the $\oint_{1} 500$ Hurst Park Foal Plate in which Lord Rosebery's Prue beat Lord Derby's Light Brigade, the International Two-Year-Old Plate at Kempton won by Research-the subsequent Derby winner Aboyeur unplaced-the Champion Breeders' Foal Stakes at Derby, in which Research was beaten by Aldegonde, and the Warwick Nursery, Indian Mail here finishing third. Five of the six races won in I 9 I 2 were all of $f_{100}$, the other one, Starboard Light's contribution, being $£_{\mathrm{I}} 6_{4}$, a total of $£_{6} 66_{4}$.

In 1913 Lord Glanely may be said to have done well, though this does not for a moment imply that his expenses were nearly balanced by his winnings. By this time it is probably well understood that owners who appear fairly prominent in the winning list have nevertheless generally lost a good deal of money, unless by chance they have been fortunate in the matter of bets. Lord Glanely's horses for I 9 I 3 made a good show. Indian Mail as a three-year-old revealed 
distinctly respectable form. Probably he was not ready at Nottingham in July, but his second effort at Manchester in September resulted in an easy win, he having carried off the Egerton Three-Year-Old Handicap in a canter by four lengths. Apparently he was not much fancied for the Wharncliffe ThreeYear-Old Handicap at Doncaster; but he wound up with a win in the Stafford Welter Handicap at Wolverhampton. Quantock won a couple of nominal $£ 500$ stakes, and the tasks set him were by no means easy ones. To begin with, he was beaten a short head by Prester Jack for the Chieveley Handicap at Newbury, and for the Stewards' Handicap at Kempton he did not get off. The Calendar records that "Quantock dwelt badly at the start," not indeed that it probably mattered very much, for Hornet's Beauty was the winner, and though he had not an unbeaten record such as that to which reference has just been made, he won eight of the twelve races in which he took part, being moreover placed for three of the others. Here the field included Prester Jack, Master Hopson, Castleton, Minehead, Meeting House, Garryhoe, and other speedy animals. But Quantock's day was coming; he won the Empire Stakes at Newbury by six lengths, having led throughout, Castleton this time second to him, and his second attempt for the Champion Spring Handicap resulted in a comfortable victory by a length and a half from Prince Kinsky's Mediator, 
Borrow third in front of Minehead, Scotch Duke, Beau Bois, Sporty, and The Angel Man.

The name of Prince Kinsky recalls a good sportsman whose sympathies were surely as much English as Austrian. There have been few more popular personages in the racing world within my memory. One of his great pleasures in keeping horses was to know that his friends had backed them when they won. Mediator, of whom mention has just been made, was much fancied for the Lincolnshire Handicap of I9I4, the year which converted the Prince into an enemy of this country; he was inclined to expect that the horse would win, having, however, some doubt as to whether the mile might not prove too far, and he took the greatest pains to explain to me just exactly how the matter stood in his opinion. The Angel Man was a curious animal. After, it is said, no fewer than thirty-three defeats—so the calculation is given, for I have not checked it-he suddenly took to winning races, and won five consecutively without a failure. Quantock's successes naturally meant increased weight. Though almost favourite for the Great Eastern Handicap he was unplaced to Harmonicon, separated from that speedy colt by such exceptionally fast animals as Diadumenos, Borrow, White Star, Halos, Moscato and Great Surprise, nor was he more prominent in the Richmond Plate behind Castleton, Diadumenos, Borrow again, with Iron Duke, Prester Jack, Sir 
Martin-who had started favourite for the Derby. La La managed a small contribution, the Sutton Selling Handicap at Birmingham. Greenmeadow also did something towards paying his expenses; after five misses he won the Delamere Handicap worth $£ 437$ at Manchester. Lord Glanely has always liked to support the last meeting of the season. Prior to this St. Vitus and Sir Josh won a race each, the former the Worcester Autumn Handicap, the latter the August Plate at Birmingham, at which meeting it will be seen the colours were often on view.

Two new names also occur in the list of winners, Maid of Sker, a three-year-old daughter of Collar and Ormah, who did not appear till Sandown in October, when she pleased her owner so much by the style in which she won the Malden Selling Handicap that he paid 800 guineas to buy her in. It was her only success, though she was a good second for a handicap at Worcester, second again for an Apprentice Plate at Derby. The other winner was The Waif, a daughter of Isinglass and Sand Path. She came out at Birmingham, running as the Sand Path filly, but making no show in the Warwickshire Breeders' Foal Plate. Four lengths was the verdict in her favour for the Midsummer Two-Year-Old Plate at Worcester, and after having been narrowly beaten at Haydock Park she won the Burton Maiden Plate at Birmingham once more. Rocksplit, who at the time of writing 
is busily engaged as a hurdle jumper after a strenuous season on the flat, the son of Pipistrello-own brother to Flying Fox-and Derelict, ran half a dozen times, never coming nearer to success than when third for the Speedy Two-Year-Old Plate at Windsor. In all eleven races, adding up to $\$ 2233$, were the result of the season.

Luck was against the stable in I9I4. Only three of the runners scored, and they took no more than a single race each. If Quantock were to win anything, however, it was intended that it should be something worth winning, it having been settled that his destination should be the stud. By way of a start he was sent for the Chieveley Handicap at Newbury, not much fancied then, as he was when next out for the Prince Albert Handicap at Sandown. He and Glencairn there shared favouritism, but neither got into the first three, Mr. R. Mills's Iron Duke winning from Mr. R. J. Farquharson's Mount William. The previous season Mount William had been backed at Newmarket to give $7 \mathrm{lb}$. to The Tetrarch, a circumstance which now seems rather odd, though at the same time Mount William won a number of good races and was more than merely useful. The horse, I may interpolate, appeared to be much attached to his owner and trainer. One morning on the Heath at Newmarket Whalley was riding him a canter when Mount William caught sight of Mr. Farquharson 
close at hand, and stopped so suddenly that he nearly shot his jockey over his head. A representative field went to the post for the Stewards' Handicap at the Kempton Park Spring Meeting, Golden Sun-who not long after dead-heated for the Stewards' CupGreat Surprise, Prester Jack, Sleipner, Castellan, sixteen in all, the speedy Adular winning the race. He was of Hungarian origin, by a horse called Bogdany, and took three other stakes during the season.

There were, it will be seen, certain races for which the horses were accustomed to run year after year. For the Empire Stakes at Newbury Iron Duke stood chiefly in the way, and in view of what had happened at Sandown it seemed a little hard that Quantock should have had to give Mr. Mills's horse i l $\mathrm{lb}$. $\mathrm{He}$ could not do it, nor did either of the two races in which he took part at Goodwood result in his favour, Golden Sun just mentioned dead-heating with the previous year's winner Lord Annandale for the Stewards' Cup, and in the King George Stakes Quantock squandered what chance he might have had by swinging round at the start and bolting. In this race an extraordinarily distinguished company of sprinters were concerned, including Harmonicon, Flying Orb, Great Surprise, Maiden Erlegh, Hornet's Beauty, Forward II. and Torchlight. La La had been disposed of; Greenmeadow made three abortive attempts, as did Maid of Sker; Little Mabel, a daughter of Land 
League, vainly strove on four occasions to help; The Waif was out twice as often, Sir Josh did nothing. Indian Mail made a satisfactory beginning in the Copthorne Plate at the Epsom Spring Meeting, but was then beaten thrice. Rocksplit, prominent for a three-year-old handicap at Birmingham, won the October Maiden Plate at Leicester, and Man of War, a son of Admirable Crichton and Bunch of Roses, not hitherto mentioned, took the Bull Ring Handicap at Birmingham. The season's receipts were $£ .387$ gained in three races.

No great improvement occurred in I9 I5. Greenmeadow, Maid of Sker, Sir Josh, The Waif, Indian Mail and Rocksplit could not win a race between them. The stable had been strengthened however; towards the end of the season Lord Glanely bought a charming filly named Tingvalla, a daughter of Fariman and Padella, from her breeder, Captain M. Laing, a member of the Jockey Club in whose colours she had borne off an important race, the Windsor Castle Stakes, at Ascot, having also been conspicuous in other rich events. She only once that season carried the black, red, white and blue belt, that having been in the Queensberry Handicap at Brighton, when in a field of twenty-two she met amongst others His Majesty's Friar Marcus, who won from Mr. A. M'Micking's Wormleighton; other runners being Sir William Cooke's Hornet's Beauty, the Vicomte Fontarce's 
Armant, Mr. F. T. Benson's Ciceromar, Mr. Kennedy Jones's Castleton, Mr. Lewisohn's Coronis, Mr. A. F. Basset's Archiestown, Sir Edward Hulton's Pennant and others who required much beating. "Archiestown and Tingvalla dwelt at the start and lost ground." So the Racing Calendar states. One is tempted to ask if the last three words are necessary. If a horse dwells at the start loss of ground is surely inevitable!

Another useful addition to the stable was The Revenge, a son of The White Knight and Santa Flora, then a three-year-old. He had not run the previous season, but hit the mark the first time he did duty, in the Spring Three-Year-Old Maiden Stakes at Newbury. At Sandown in the Tudor Plate he fell, as did the favourite, Lord Rosebery's Vaucluse. A victory in the Kempton Maiden Plate at Kempton followed, but then came a string of defeats, he being asked to do a good deal, in some cases a great deal. He ran in Pommern's substitute Derby, also for the Irish Derby; having shown himself to be a stayer he started second favourite for the Middle Miles Handicap at the Newmarket Fifth Extra in September, ran for the Cesarewitch, for the Rutland Stakes at the Houghton, second to the four-year-old Golden Rule, giving him $8 \mathrm{lb}$. and the year. Nicky Nan has perhaps a somewhat feminine sound, but he was a son of St. Frusquin and Belle Poule. He won a Selling Plate at Salisbury, after which no one would bid for him and he did not long 



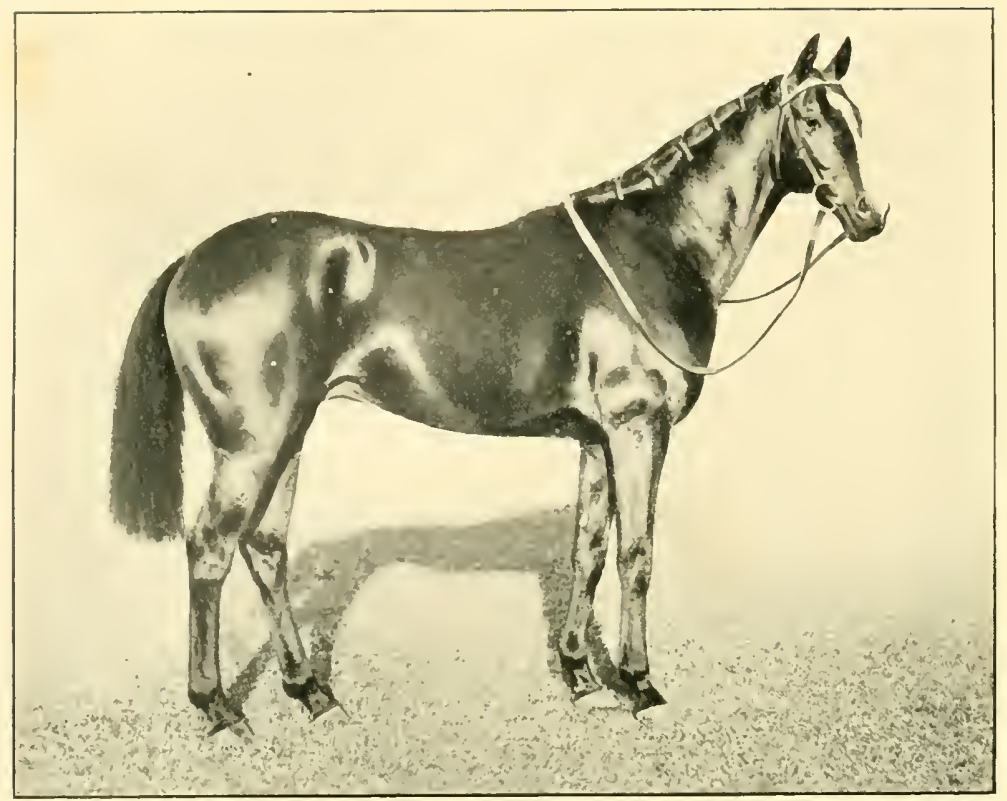

Photo: II. A. Rouch

GRAND FLEET

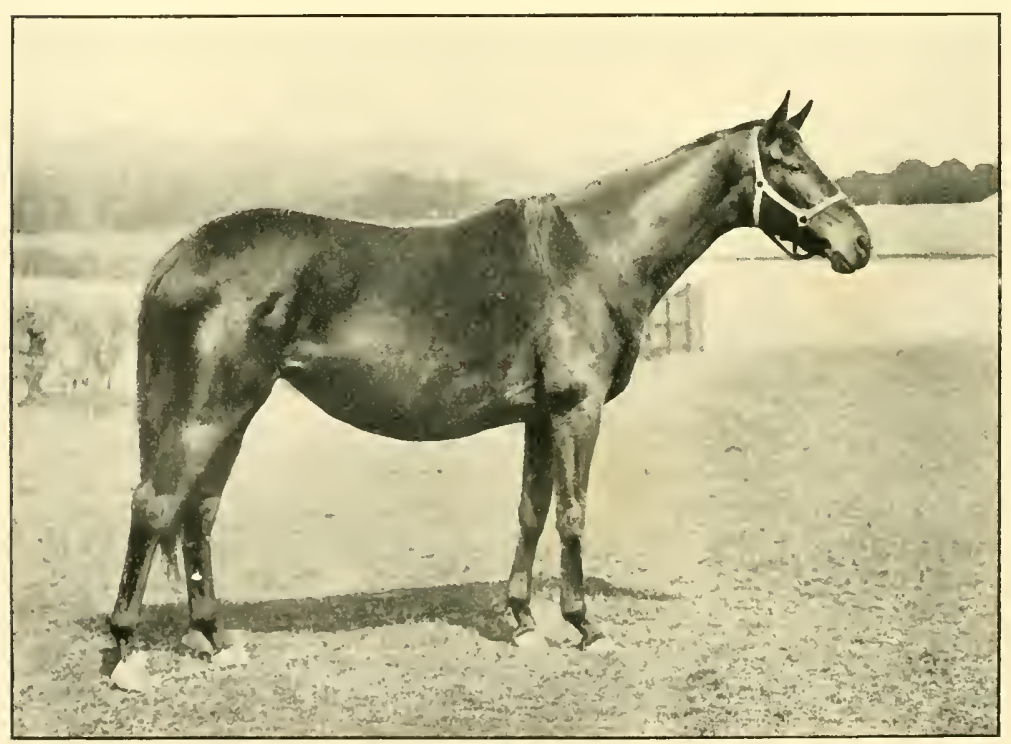

Photo: W'. A, Rouch

QUEEN EMPRESS 
remain in the stable. Still he figures in the return as winner of one of the three races which showed a slight advance on the previous season, adding up, however, to no more than the very modest amount of £527. It should be stated that some of the horses had been transferred to the care of de Mestre at Bishop's Cannings in Wiltshire.

In I 9 I 6 there was a distinct move upwards, chiefly owing to Grand Fleet, the son of Bachelor's Double and Dark Dinah, purchased at the Newmarket July Sales for the trifle of 320 guineas, an extraordinary bargain for the purchaser. The Revenge, Tingvalla and Little Mabel added to the record of success, but the advance was mainly owing to the Dark Dinah colt, as Grand Fleet was called when he won his earlier races. He was recognised as a horse of class and much fancied for the Manton Two-Year-Old Plate at Newbury, where that season three meetings were permitted. It may be well to note in passing that during the anxious period of the war there were besides the eight regular fixtures at Newmarket, three extra ones, three at Gatwick, four at Lingfield, three at Newbury and two at Windsor. Sir Edward Hulton's Greenmount, a 7 to 4 favourite for the Manton Stakes, ran badly, and the Dark Dinah colt, starting at 9 to 4 , was beaten three parts of a length by Mr. H. S. Persse's Publican.

The experience gained stood the colt in good stead, 


\section{A GREAT YEAR}

and he won his next four races. Mr. H. MallabyDeeley had followed the example of his brother, $\mathrm{Mr}$. Frank Curzon, and bought some horses, one of whom, Fleetwood, a daughter of Cicero and Will Return, picked up for 260 guineas, had shown a little early form. She had won the Fitzwilliam Stakes at Newmarket and was made favourite for the Newmarket Two-Year-Old Plate, to be easily beaten three lengths by Lord Glanely's colt. He won the Spring TwoYear-Old Stakes from Lord Derby's Marchetta filly, herself a winner, the Ditch Two-Year-Old Stakes at the First Summer Meeting, giving Fleetwood rolb. over weight for sex and a two lengths beating, and was then victorious in a more important event, the July Stakes, for which Lord Derby's filly finished second. The Dark Dinah colt started at 9 to 4 on. Though beaten in four other races he always ran well. No doubt was entertained of his staying the six furlongs in the Exeter Stakes; but he had to give $8 \mathrm{lb}$. to $\mathrm{Mr}$. Hulton's Knutsford, regarded by Mr. Dawkins, the official handicapper, as the best of his year, I $2 \mathrm{lb}$. also to Mr. J. Buchanan's Athdara, who could gallop when disposed, though his disposition nearly always kept him in the background. Lord Derby's son of Fowling Piece and The Tabard, afterwards called Coq d'Or, in receipt of $\mathrm{I} 2 \mathrm{lb}$. beat Grand Fleet, running under this name for the first time, three-quarters of a length for the Clearwell, and then came the Middle Park. 
Here odds of 2 to I were laid on Captain Giles Loder's Molly Desmond, the daughter of Desmond and Pretty Polly, who had won both the races for which she started. She was beaten a head by Mr. J. B. Joel's North Star, Grand Fleet giving $3 \mathrm{lb}$,, third, beaten two lengths from the second; and he was again third for the Criterion. Mr. Fairie's Gay Crusader, 8 st. $8 \mathrm{lb}$., won a head from Molly Desmond, Grand Fleet 9 st. 4 lb. only a neck away. It will have been perceived that he was a colt of the highest class.

At Gatwick in 1916 the first meeting of the year took place, and Tingvalla was sent to run. She never quite fulfilled her early promise. In the Horley Handicap carrying only 6 st. $9 \mathrm{lb}$. she did nothing, an excuse perhaps being that she was not expected to do much thus early in the season. Advanced in condition she was brought out at the Newmarket Second Extra against some extremely formidable opponents, notably Lord Derby's Phalaris and Mr. Hulton's Torloisk. Tingvalla was backed, unremuneratively however. At the Newmarket First July a humbler occupation was found for her. She ran for an Apprentice Plate and won it by a neck from Pennant, who was giving her $15 \mathrm{lb}$. This of course does not say very much for her form, except indeed that form can seldom be judged with accuracy when apprentices are riding. She made a much more ambitious attempt at Windsor in the $£ 1000$ St. George's Handicap, for here were 
Phalaris and Torloisk again, together with Lord Carnarvon's Volta, Mr. Stern's Salandra-a very speedy colt who won in England and then in Indiaand Mr. L. Neumann's Argos, the last named a 2 to I favourite whom Phalaris beat by six lengths. In the St. Ives Handicap again at the Newmarket Third Extra Tingvalla was asked to do too much, and her only other win was in a second Apprentice Plate at Newmarket in the autumn,

The Revenge stayed so well that he was thought to have a sound chance in the Thatcham Long Distance Handicap at Newbury. This he missed, soon after making amends by winning the Winchester Handicap at Windsor, and he came very near to following on with the July Course Handicap, for which Colonel George Holdsworth's Sybarite, a four-year-old like himself, beat him half a length, in receipt of $24 \mathrm{lb}$. This was the Ist of June, and on the Ist of July we find the horse described as the property of "Sir W. J. Tatem," the title having been conferred upon the owner just previously. The only other winner was Little Mabel. She took the Second Class of the Manor Double Handicap at Gatwick, beating the favourite, Mr. P. F. Hartigan's Irish Brigade. A two-year-old named Argosy, a son of Bachelor's Double and Fragrant, made one appearance, in the First Spring Two-Year-Old Stakes, in which a good filly belonging to Mr. Hulton, Margarethal, beat 
Mr. Walter Raphael's Tagamor, a 7 to 4 favourite, by a head, Margarethal being a 20 to I outsider. Nicky Nan won a race, but Lord Glanely had by this time got rid of him. The eight stakes produced f.3608.

Grand Fleet reappeared for the Two Thousand of I 9 I 7 , supposed to have an outside chance, for I 00 to 7 was taken about him. At this period Gay Crusader was supreme, and he won, though only by a head from a stable companion, the present Lord Astor's Magpie; Athdara—one of the last occasions on which he was persuaded to gallop-third in front of $\mathrm{Mr}$. Reid Walker's Invincible. When horses take part in classic races handicappers take notice. Grand Fleet, sent to Ireland to run for the St. Patrick's Stakes at the Curragh, had 8 st. $9 \mathrm{lb}$. allotted to him. That meant giving I I lb. to Quarryman, the same weight to By Jingo, a prospective Gold Cup winner, and Grand Fleet had his journey in vain. Returning to England he met a good field in the July Handicap at Newmarket. Here Mr. J. L. Dugdale's Foxton was favourite and justified the selection by beating the very useful Quarryman, who soon afterwards went to India to become one of the leading performers there. Magpie, it may be noted, was bought by an Australian owner for whom he did good service.

Many spectators thought that Grand Fleet had won the Salford Borough Handicap at Manchester. He 
had in fact failed by a head to give $4 \mathrm{lb}$. to Lord Durham's Roscius, easily beating Mr. F. Stobart's Roubaix, another exportation to India, and one of the most successful seen there for some years past. $\mathrm{He}$ and Quarryman frequently ran together, and speaking from memory I think they were in the habit of beating each other. With Donoghue up Grand Fleet won the Stockton Handicap, and survived an objection on the ground of a cross. Perhaps the Stewards were generous in allowing the return of the deposit. That, however, was Grand Fleet's solitary success, though he distinguished himself in the Cambridgeshire by running third to Sir Abe Bailey's good colt Brown Prince with Mr. Barclay's Planet second. All these three were three-year-olds and Grand Fleet was giving $6 \mathrm{lb}$. to both the first and second.

But though Grand Fleet was scarcely successful in the matter of earning money, the year was a fortunate one for his owner, who was now beginning to collect a number of really good horses, indeed there was in I9I7 a foreshadowing of the Great Year-that is to say if all went well, for Lord Glanely had seen enough of ownership to know that rosy prospects were very apt to fade. Happily this was not the case here. Argosy was reproduced at the Newmarket Craven Meeting in an Apprentice Plate, with which he cantered away by six lengths, and he made his mark by winning the Hastings Plate by a length and a half from Mr. Frank 
Bibby's St. Tudwal, Coq d'Or, almost as good a favourite as Argosy, a length and a half behind the second. The colt was then sent over to run for the Irish Derby, starting a slightly better favourite than Lord Wavertree's Kingston Black, 2 to I and 5 to 2 respectively; but the race went to First Flier, who beat Argosy by five lengths, Kingston Black having been left at the post.

An important first appearance was that of Scatwell. This son of Marcovil and Cheshire Cat was made favourite in the first instance for a race which proved a regular fiasco, the Tuesday Two-Year-Old Plate at Newmarket in July. There were twenty-six runners, and just about half of them broke away before the flag fell, Scatwell favourite at 3 to $I$. The flag had not fallen, it was not a start, though some of the horses fatigued themselves by galloping the entire course. It was in fact the fiction of a race which meant nothing, except, indeed, an endless controversy about the proper starting price. By some people the Committee of Tattersalls were severely blamed for their verdict. Others strenuously supported them, and echoes of the controversy are heard to the present day. The names of the Committee are published in several Turf Guides, there is no secrecy about the composition of the body, and all who care to know may be aware that for many years I have been one of them. During the period of arduous service which 
I have given to the Committee I have had a voice in the decision of some thousands of disputes, but I was never more confident than in the case of that Tuesday Two-Year-Old Plate. My argument is that there cannot be a race unless the horses are started according to rule and unless the Judge gives a verdict. In what has come to be called the Pandion case a number of the horses broke away on their own account, and of those who passed the Judge's box that functionary took no notice. Yet the critics of the Committee's ruling would have it that this was a genuine race and that when rather more than half of them returned to the starting place, were duly dispatched and duly placed by the Judge, that was not a race at all ! If it is obstinacy to maintain my original view I certainly remain obstinate.

Scatwell reappeared for a Maiden Stakes at the Newmarket Second Extra Meeting, again started favourite, this time at 7 to 4 , and won easily by a length. He ran a third time at Newmarket in August for a race called the Ramsey Plate. This time Mr. Hulton's Violinist was favourite and won, Scatwell giving him Io lb. was second, beaten a length, Gainsborough, who was to make a great name for himself, receiving ro lb. from Scatwell, finishing two lengths behind Lord Glanely's colt. What Scatwell had done was sufficient to induce Mr. Dawkins to place him at the top of the Free Handicap with 9 st., Gainsborough following 


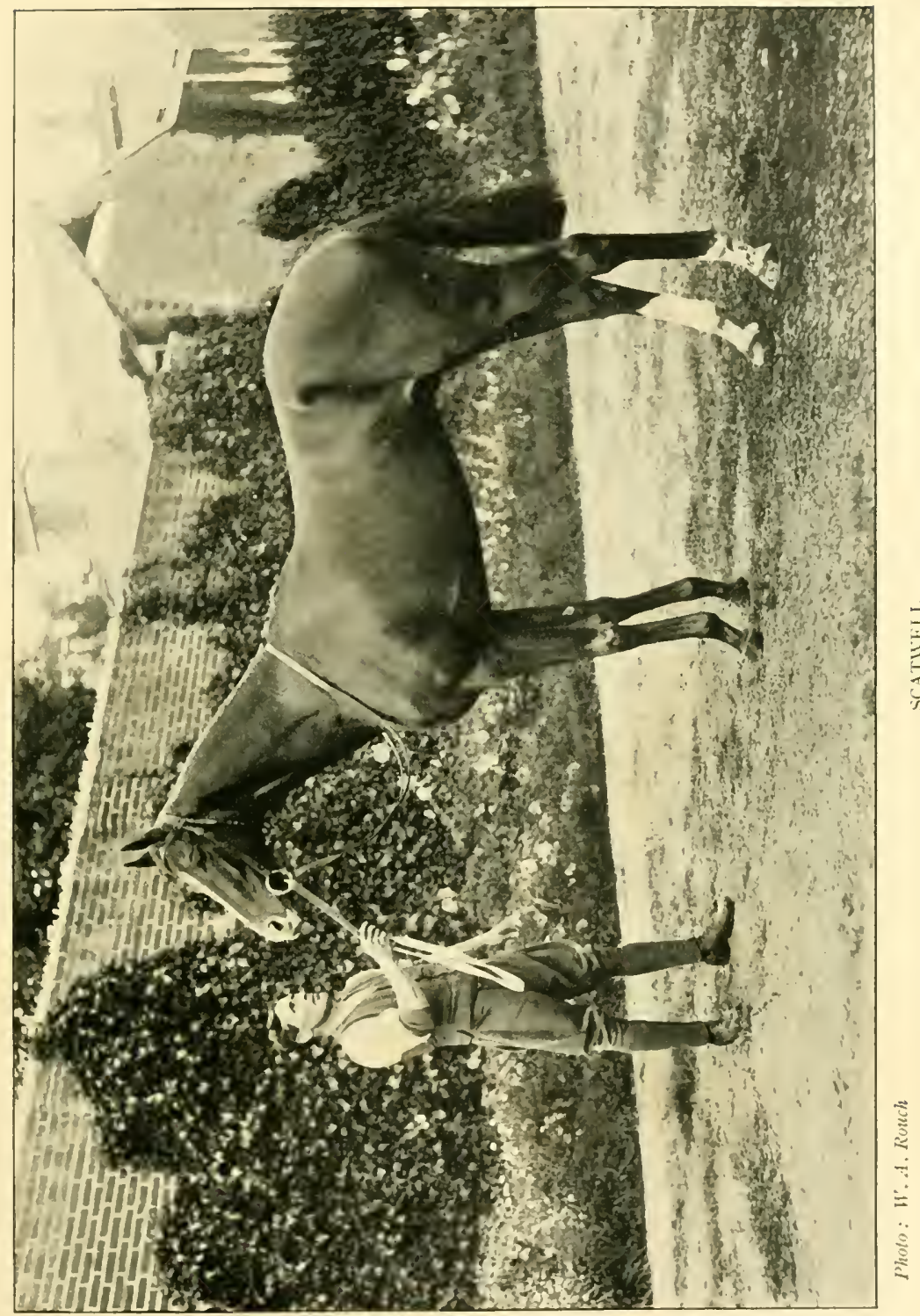



with 8 st. Io lb., on the same line with Violinist; next a good filly belonging to the late Lord Londonderry, Benevente, 8 st. $9 \mathrm{lb}$.

There was another colt moreover who had proved to be $7 \mathrm{lb}$. in front of Scatwell, this being Skyrocket, a son . of Sunstar and Maid of the Mist, the dam a daughter of Sceptre by Cyllene. He began with a success, having the best of a finish with Sonning and Hillhampton for the Princess's Plate at the Newmarket Second July. Though he won nothing more he by no means lost caste, for when beaten half a length for the Chesterton Nursery at one of the Extra Meetings he was giving no less a weight than $22 \mathrm{lb}$. to a smart colt named Rocksavage belonging to Sir William Cooke. In the Middle Park Plate he was third to Benevente and Herself, giving the latter $4 \mathrm{lb}$. more than weight for sex, and in a Nursery at the Houghton Meeting, when Herself beat him by three parts of a length, she had a I $5 \mathrm{lb}$. the better of the weights. Skyrocket in the Free Handicap had 8 st. $8 \mathrm{lb}$., that is, he was placed $6 \mathrm{lb}$. below Scatwell, an estimate which, as just observed, did not accord with that of the stable. Scatwell and Violinist are among the many horses who found their way to India.

Another two-year-old not unworthy to rank with these was a son of Tredennis and Clare, presently to be known as Treclare. He started in Ireland, going for. the Camp Stake at the Curragh June Meeting, where 
he shared favouritism with Goldgainer, and in the hands of Donoghue won in a canter by eight lengths. Lord Glanely was a liberal patron of the Irish Turf; but his horses were primarily intended to run in England, the Clare colt came over for the Newmarket First Extra in August, dividing Benevente and Somme Kiss for the New Coventry Stakes, designed to be a substitute for the Coventry Stakes at Ascot, and so an event of importance. For the Wynyard Plate at Stockton odds of I 00 to 30 were laid on him and landed, but next day he failed to give $12 \mathrm{lb}$. to Cheechako, and found $8 \mathrm{st}$. I $2 \mathrm{lb}$. too much in the Free Handicap, which went to Zinovia, who was to win the Cambridgeshire next year. Sweetness, a half-sister by Morena to Argosy, showed some form. She was third to Earna for a race at the Third Extra, and won a Maiden Plate at the Fifth Extra, beating Old Drury, Sir Berkeley, who was so continually backed and beaten till his right course, a mile and a half, was discovered, Langdon Hills, a winner of the Great Metropolitan, and Ferry, the daughter of Swynford and Gondolette who created general amazement by beating that good mare My Dear for the One Thousand Guineas. There have been several surprises for this classic but none more startling than the victory of Lord Derby's 50 to I outsider.

White Squall, a daughter of White Eagle and Elm Twig, a regular Wavertree pedigree, ran twice for 
Lord Glanely, the first time successfully. All sorts of hitherto unknown names were devised for races at the Newmarket Extra Meetings. One of them was the Oakington Plate, in which White Squall had a head the better of Mr. J. B. Thorneycroft's Damask. In amount the nine races won did not bring in quite so much as the eight had done the previous season. The total was $\oint_{294 I}$; but Lord Glanely could regard the future with a certain amount of complacency, having now some really good horses to run for him.

The year I 9 I 8 proved that this attitude was justified, and there was additional satisfaction in the circumstance that two of the winners were homebred, Somerset Lassie being a daughter of Quantock and The Waif, Lady Juliet of Mercutio and Lady Fowler. Neither of them did much, it is true, but there is always something particularly welcome in the success of horses homebred. Somerset Lassie was allowed to begin in a Selling Race at the Newmarket First July, another of Lord Glanely's being in the field, Royal Welsh, a son of St. Amant and Royal Applause. $\mathrm{He}$ was thought the better of the two and started second favourite at 5 to $I$, neither finishing in the first three behind Fussy. It was, by the way, fortunate for Mr. C. E. Howard that no one claimed Sunny Rhyme, who has won a number of races for her owner. Somerset Lassie just won the Fakenham Nursery from Valley and Mr. Howard's filly just 
mentioned, and was elevated to $8 \mathrm{st}$. I $2 \mathrm{lb}$. in the Second October Nursery. She had come on, and her owner did not care to risk her again in Selling races, though, of course, had she taken one it does not follow that he would have let her go.

Lady Juliet scored at her first attempt in the Surrey Two-Year-Old Stakes at one of the Extras, behind her being Monte Faro, Vain Dream-running in the name of Lord Marcus Beresford as all the King's horses were doing at this period-and Sentry. Her other essay was in a Home Bred Plate, when, starting favourite, she was beaten two heads by Blase, to whom she was giving a stone, and Knight of Blyth, giving her I lb. instead of the $3 \mathrm{lb}$. weight for sex. There were twenty starters, and the filly's performance must be esteemed an excellent one, seeing that Knight of Blyth after losing the Middle Park Plate by no more than three parts of a length won the Dewhurst. Royal Welsh it may be added won the Bentinck Fund Nursery at the Newmarket First October Meeting from Knight of Blyth by a neck, but the winner was in receipt of $\mathrm{I} 6 \mathrm{lb}$.

I have begun with these fillies for the reason indicated and notwithstanding that there was a runner destined to make a deep mark in Turf history, a colt of whom it is the more desirable to write an account because, as will be understood, justice has never quite been done to him, in spite of the fact that his record is only 
marred by a single defeat for which there is legitimate excuse. Grand Parade, a beautiful very dark brown colt, described indeed as a black, by Orby out of Grand Geraldine, came out at the Craven Meeting with sufficient reputation to cause him to start favourite at 3 to $I$ for the First Division of the FitzWilliam Stakes, and the verdict of two lengths does not suggest the ease with which he won. Mr. J. B. Joel's Petrol, quite a nice colt, had been backed at 7 to 2 , and the pair met again when Grand Parade appeared a second time in the Soltykoff Stakes at the Second July. Here Petrol was favourite, for Grand Parade had to give him $8 \mathrm{lb}$. Carslake rode an excellent race on the son of Sunder and got to within a neck of Grand Parade as they passed the post. There is a theory that two-year-olds manage to give away weight better than do their seniors; weight nevertheless will always tell.

A number of Irish engagements had been made for Grand Parade; he was sent to fulfil some of them, and ten days after his Newmarket success he secured a Biennial at the Curragh from opponents whose names would convey little impression to the majority of English readers. At the Curragh his next victory was also achieved two months later in the Anglesey Stakes, and he waited there another month for the National Produce Stakes on the same course, a prize of $\oint_{\mathrm{I}} \mathrm{I} 86$, which is a large one for Ireland. He had 
so little to do that odds of 20 to I were laid on him. After this he was hurried over to England to run for the Moulton Stakes at the Houghton Meeting, and, as the event proved, it would have been better to have spared him, as he was by no means at his best after his journey. Knight of the Air, who following on a victory at an Extra Meeting had lost the Hopeful Stakes by a head, was favourite at a shade over evens, as much as 9 to 2 being finally laid against Grand Parade-after he had opened at even money-and Glanmerin, the property of the late Lord Herbert Vane Tempest-like Grand Parade Glanmerin is a son of Orby-was also considered to have a good chance; as proved to be the case, for he won a head from the favourite, Grand Parade, beaten two lengths, suffering the only defeat of his career.

Racegoers in general were not a little puzzled as to whether Grand Parade was really the best two-year-old in the stable, for there likewise was Dominion, a son of Polymelus and the Desmond mare Osyrua, a good colt, but not a lucky one, for on several occasions he was barely beaten and in one case with a fair field and no favour would almost certainly have won. He had been so well tried that odds of 5 to 4 were laid on him for a Maiden Plate at the Craven Meeting, an optional Selling Race, in which Vice Reine, benefiting by a previous experience and a selling allowance, ran him to a neck. For the Ditch Two-Year-Old Plate at the 


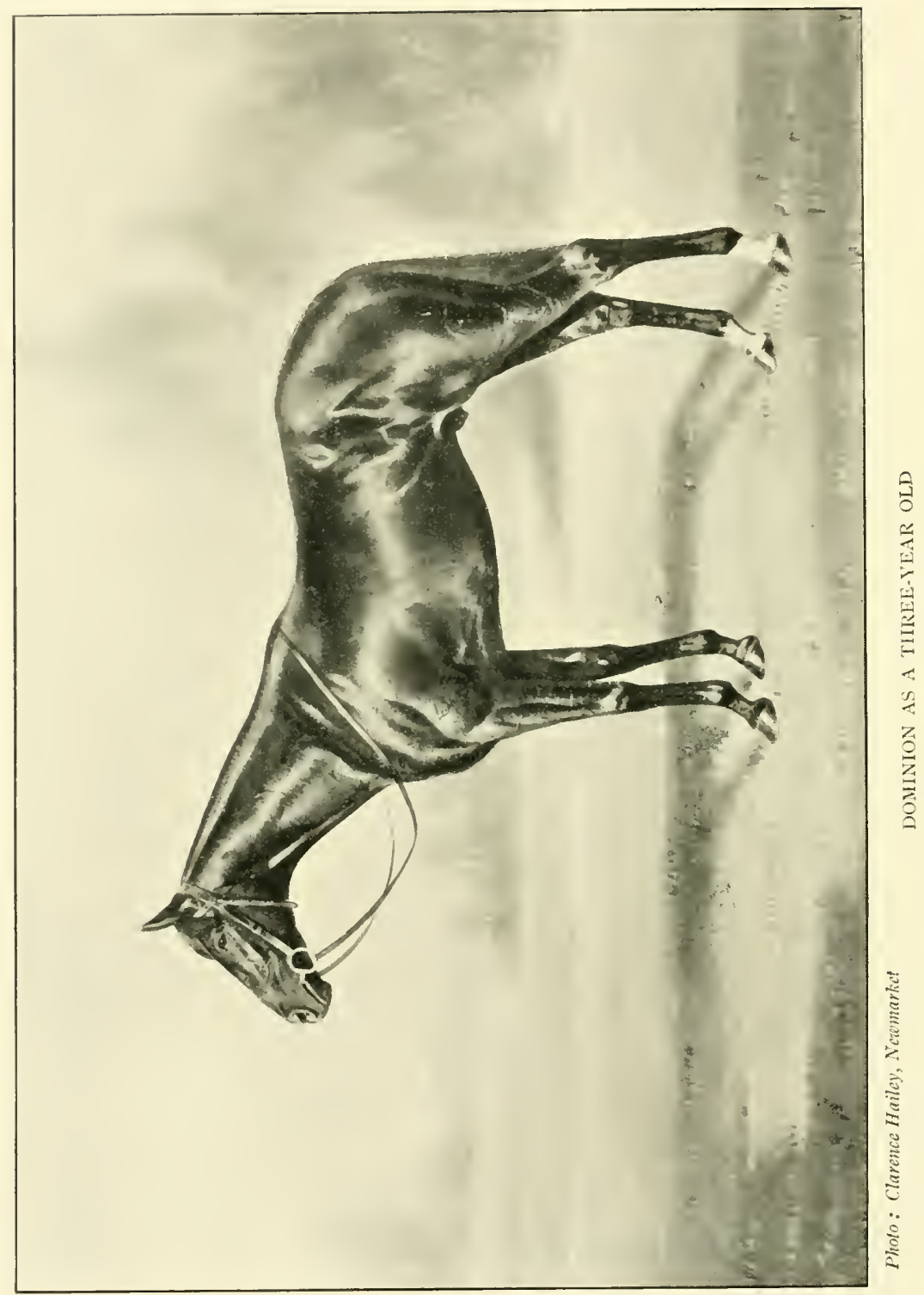


First Summer Meeting-so a fixture at Newmarket was called in 1918-Milton, then known as the Misfit colt, was in chief demand at 2 to I. Admiral of the Fleet Sir Hedworth Meux's Mille Fleurs colt, who was to make a reputation as Sir Douglas and to hold out promise of great things not fulfilled because of unsoundness, was not fancied, but Dominion beat the favourite, giving him moreover $5 \mathrm{lb}$., and as a consequence found plenty of supporters at 9 to 2 for the Coventry Stakes, though Galloper Light was preferred at II to 8 . Sir George Noble's Bruff Bridge had at this time won a couple of races, the May Plate and the Somerville Stakes, and here was too good for his rivals, beating Monte Faro a neck, Dominion third, in front of the subsequent Grand Prix winner.

For the Exeter Stakes Dominion was again third, giving $8 \mathrm{lb}$. to Lord Rosebery's Rizzio, notable as the son of two Derby winners, Cicero and Signorinetta; Dominion meeting Bruff Bridge at even weights. It was an unsatisfactory race for the reason that G. Hulme, who rode Rizzio, got away with a distinct lead which more than probably accounted for the result. The jockey was called before the Stewards and fined for " anticipating the start." Bad luck again attended Dominion in the Chesterfield. This was assumed to be a match between Buchan and Lord Glanely's colt, the two backed at 5 to 4 and 6 to 4 respectively, and the estimate was extraordinarily correct. Buchan won 
a head; but whether he would have done so if the pair had been three or four feet apart is another matter. An anticipated objection to Buchan for bumping and boring was promptly laid, to be however overruled. Dominion started favourite for the Middle Park Plate and ran well. At this period there was a colt by The Tetrarch called Stefan the Great whose friends regarded him as second to none, and he took the race by three parts of a length from Knight of Blyth, Dominion a neck away third. In the Free Handicap with 8 st. 8 lb. he by no means ran up to his form.

There was another winning twc-year-old in the stable in Exford, a son of Marcovil and Lanford, who started at Birmingham by winning the Coventry Plate in a field of eighteen from a useful filly named Daphne, and Monte Faro. Exford missed the First Extra Two-Year-Old Stakes by a head and a neck, giving $7 \mathrm{lb}$. to the first and second, distinctly useful colts, Violoncello and Viceroy.

Of the older horses Grand Fleet continued his disappointing career. Carrying 8 st. I 2 lb. he disposed of a big field for the Crawfurd Plate, winning a head from Lord Derby's Hainault and sixteen others, an encouraging start which made his failures more exasperating, as this was the only race he won throughout the season. Of course he was asked to do much. Diadem beat him out of a place for the Bretby Handicap 
as she did again for the Salford Borough Handicap, in which that remarkably handsome and capable colt Irish Elegance took part. Grand Fleet ran up against Irish Elegance again in the Cambridgeshire Hunt Plate, and was beaten in the Cambridgeshire among other races.

Some compensation was forthcoming in the upward progress of $\mathrm{He}$, the son of Santoi and She, who had developed in quite an extraordinary way. I omitted to mention his one uneventful appearance as a twoyear-old, for there was nothing to say about it except that he had run as well as he was expected to do. At the Newmarket First Spring Meeting $\mathrm{He}$ showed speed in the Chippenham Plate, won by King John, subsequent winner of the Irish Derby, and then took a Welter Handicap at the First Extra. He did much better by defeating a useful field of staying horses for the Summer Handicap, among them St. Tudwal and The Viking, both greatly fancied, Furore, a winner of the Cesarewitch, also St. Eloi, a winner of the Alexandra Plate at Ascot. He continued to thrive so well that when the Cesarewitch weights were published his 7 st. Io lb., a very respectable allotment for a three-year-old, was by no means thought to be too much for him, on the contrary he was regarded as having so excellent a chance that he started a good favourite for the chief of long-distance handicaps, a selection which came just as near to success as possible. In a 
desperate finish Air Raid beat him by a head, which is specially described in the Calendar as a short one.

NEWMARKET Second October Meeting.

Wednesday, Oct. 16th, 1918.

CESAREWITCH STAKES (Handicap) of $£ 25$ each, io $\mathrm{ft}$. for acceptors, with $£ 500$ added, of which second recd. $£ 100$ and third $£ 50$; entr. $£ 5$, only $\mathrm{ft}$. if dec. Cesarewitch Course, $2 \frac{1}{4} \mathrm{~m}$. (58 ents. $£ 5 \mathrm{ft}$. dec. for $25-£_{1} 1010$.)

Mr. W. M. Cazalet's b. or br.c. Air Raid, by

Willonyx-Ayrslave, 3 yrs., 8 st. I lb - O. Madden I

Lord Glanely's He, 3 yrs., 7 st. 10 lb. - Arthur Smith 2

Major F. C. Stern's Buckthorn, 3 yrs., 7 st.

I lb. - - - - - - - G. Hulme 3

Mr. H. Ellis' Furore, 5 yrs., 8 st. 12 lb. - H. Robbins 4

Mr. Donald Fraser's Brown Prince, 4 yrs.,

9 st. 2 lb. - - - - - - F. Fox

Mr. W. M. G. Singer's St. Eloi, 6 yrs., 9 st. J. Childs

Mr. L. Winan's Planet, 4 yrs., 9 st. - - B. Carslake -

Mr. W. T. de Pledge's Greek Scholar, 5 yrs.,

8 st. $3 \mathrm{lb}$.

Mr. J. White's Chapel Brampton, 6 yrs., 8 st.

A. Whalley

E. Wheatley

Mr. J. E. Potter's Golden Rule, aged, 7 st. II lb. - - - - - -

Capt. Brian Bibby's St. Tudwal, 4 yrs., 7 st. I lb.

Duc Decazes' Mont Saint Eloi, 3 yrs., 7 st. $7 \mathrm{lb}$

M. M. Calmann's Haki, 6 yrs., 7 st. 5 lb.

Mr. L. Winan's Race Rock, 6 yrs., 7 st. 5 lb.

Mr. J. White's Ivanhoe, 5 yrs., 7 st. 2 lb. (car. 7 st. 3 lb.)

Mr. A. E. Barton's Leandros, 3 yrs., 7 st. $2 \mathrm{lb}$.

V. Smyth

C. Foy

J. H. Martin J. Brennan -

J. Mason

R. Cooper

C. Ringstead 


\section{THE GRADUAL RISE}

Mr. Douglas Stuart's Chinaman, 4 yrs., 7 st. I lb.

Mr. R. W. Tilley's Morning Star, 3 yrs., 6 st. I I lb.

Mr. Sol Joel's Princess Nathalie, 3 yrs., 6 st.

Sir H. M. FitzHerbert's Mountain Laddie, 5 yrs., 6 st. 7 lb. (car. 6 st. Io lb.) - Mr. W. McIlroy's Pastures New, aged, 6 st.

$9 \mathrm{lb}$

Mr. P. W. Carr's Warwick, 4 yrs., 6 st. 9 lb. . Mr. G. W. Smith's John Jackett, 5 yrs., 6 st. $5 \mathrm{lb}$.

K. Robertson T. Leader G. Lester E. Quirke Mr. W. H. Dixon's Traceable, 3 yrs., 6 st. (car. 6 st. 3 lb.) T. Oates A. Flanagan T. Weston (car. 6 st. 3 lb.) - W. Balding

II $/ 2$ agst. $\mathrm{He}, \mathrm{IOO} / \mathrm{I} 5$ Furore, IO/I Greek Scholar and Ivanhoe, I00/9 Haki and St. Tudwal, I00/6 Brown Prince, 20/I Golden Rule and Buckthorn, 25/I Air Raid, 33/I Planet, Race Rock, Leandros, Morning Star, and Princess Nathalie, 40/I St. Eloi, 50/I Mont Saint Eloi, Chapel Brampton, and John Jackett.

Won by a short head, $\mathrm{I} \frac{1}{2}$ lengths second and third.

That good filly Benevente stood in the way of Treclare for the Craven Stakes, but in a field of twentyeight he carried off a Three-Year-Old Handicap at the Newmarket First Spring from Jutland, giving His Majesty's colt $22 \mathrm{lb}$. Jutland was a 2 to I favourite, indeed so much was Lord Glanely's colt underrated that he started at 20 to I. For the once valuable Newmarket Stakes-still on this occasion worth £2530-Treclare was beaten less than a lengththree-quarters and a head-by Somme Kiss and Thermogene, and he next ran in the Derby. Gains- 
borough was considered to stand out, indeed he did so to such an extent that his backers were agreeably surprised at being able to lay as little as I 3 to 8 on him, the next quotation being 8 to I, taken about Zinovia. Treclare here again was at 20 to $I$, a remunerative investment for those who supported him both ways, as he ran a creditable third to Gainsborough and his stable companion Blink. A placed horse in the Derby does much to qualify for the stud. Treclare only ran once more, and what occurred furnished unmistakable evidence that he could not have been nearly himself. As just observed, he had given Jutland $22 \mathrm{lb}$. in the Spring; at the Newmarket Second July in the Dullingham Plate Treclare was beaten, though no more than a short head, in an attempt to give Jutland merely $4 \mathrm{lb}$.

White Squall comes into the story as winner of the Mildenhall Plate. She was allowed to try her luck in the New Oaks, though it was realised that she could not be in the least likely to beat My Dear. It was not a little surprising that Scatwell should have failed to score throughout the entire season. He began by running second for the Column Produce Stakes to Lord Durham's Callander, though seeing that Callander was quite a useful colt there was no discredit in inability to give him as much as $18 \mathrm{lb}$. It was not supposed that Scatwell had lost his form, so little was this the case, indeed, that for the Two Thousand he started 
at 3 to I, a better favourite than Gainsborough, who was on offer at 4 , Polyscope being the general choice and backed at 7 to 4 on the strength of a private reputation which greatly exaggerated his merit. Scatwell did not distinguish himself and was in retirement until October. In a Triennial he encountered My Dear, and though she was giving him $9 \mathrm{lb}$., odds of 7 to 2 were laid on her. Scatwell was fourth, Roideur also beating him many lengths. His deterioration was obvious, for in the Select Stakes he was unplaced to Callander, Lord Durham's colt this time giving him I $2 \mathrm{lb}$., instead of receiving i $8 \mathrm{lb}$. He did no better in the Houghton Handicap. The season as a whole was of course by far the best Lord Glanely had experienced, with sixteen races worth $£ .6626$ I2s. $6 \mathrm{~d}$. to his credit. 


\section{CHAPTER III}

\section{THE GREAT YEAR}

As the rgrg season approached Lord Glanely's prospects looked distinctly good, except that a great consensus of opinion regarded Sir Alec Black's The Panther as invincible for the Derby. The colt had not done anything very remarkable as a two-year-old. He had been beaten in his first race by Mr. Anthony de Rothschild's Galloper Light, had then won a Maiden Plate, from a large field, indeed, but of for the most part bad horses, none of them beyond the rank of plater. A third and final effort at a Newmarket Extra Meeting had resulted in a success which was certainly creditable. As a matter of course the colt must have done something to account for the prestige he was supposed to enjoy. In his third race he beat Lady James Douglas's Bayuda by three parts of a length, Galloper Light third, a length and a half away, but giving the winner as much as Io lb. Bayuda had then won nothing. The craze for The Panther always struck me as inexplicable. He was not in what is called a "fashionable" 
stable, his trainer had not any brilliant record of past victories to encourage belief in his charge; nevertheless, by a considerable section of racegoers the son of Tracery and Countess Zia was accepted as a wonder, and when it became known that he would be sent up to auction with a reserve of 40,000 guineas on him his enthusiastic admirers declared that he was extremely cheap. His victory in the Classics these eulogists regarded as a foregone conclusion.

Some writers on Turf affairs cannot apparently be persuaded that the Keeper of the Match Book does not make the Free Handicap for Two-Year-Olds. As a matter of fact it is made by the Official Handicapper. Mr. T. F. Dawkins was responsible for it in the autumn of I 91 8 , and he put The Panther first, though by no more than a couple of pounds. Occasionally the weights have gone up to $9 \mathrm{st} .7 \mathrm{lb}$. This was not so in I9I8. The Panther had the usual 9 st., which placed him $2 \mathrm{lb}$. above Grand Parade and Galloper Light, who were thus jointly put in with 8 st. I 2 lb., I lb. in front of Sir W'alter Gilbey's Paper Money, after whom, yet another pound lower, came $\mathrm{Mr}$. Lionel Robinson's Stefan the Great. This grey son of The Tetrarch was a colt whose devotees placed him on a pinnacle, due to what he had done at home and quite possibly well deserved, though his career was destined to be short. Mr. S. B. Joel's Polygnotus 
and Mrs. Whitworth's Iron Hand had both 8 st. 8 lb., and Lord Glanely's second string, as Dominion was then considered-not without reason in spite of the Derby betting-stood at 8 st. $5 \mathrm{lb}$. Sir George Noble's Bruff Bridge was esteemed only a pound below, and of the fillies, though Lady Juliet had only run twice and won once, she was supposed to have no superior amongst her sex but an equal in $\mathrm{Mr}$. W. H. Dixon's Lady Farmer. This could only mean that the fillies were poor. Lady Farmer had been beaten in four of her five races, none of them stakes which count for very much, and in the race she won by three parts of a length the second, Lady Nelson's Tetrarchia, was giving her $7 \mathrm{lb}$. It almost always happens that some two-year-olds have appeared too late to be included in the Free Handicap, and this was the case with Lord Astor's Lord Basil, who had only been out once, when he carried off the Buckenham Stakes. He and his owner's Buchan, the latter also strangely omitted from the Free Handicap for he had won thrice before it was compiled, were considered to have leading chances in the classics, outsiders with modest support being Mr. C. T. Garland's Milton and Lady Torrington's All Alone. But in such betting as was quoted in the Spring of I 9 I 9 The Panther dominated the market.

Lord Glanely did not begin the season with an exceptionally numerous string. His horses in training 
by Barling at Newmarket numbered 29 in all, made up as follows :-

I. He. 4 yrs. Bay colt by Santoi-She.

2. Sky-rocket. 4 yrs. Chestnut colt by Sunstar-Maid of the Mist.

3. Scatwell. 4 yrs. Chestnut colt by Marcovil -Cheshire Cat.

4. Treclare. 4 yrs. Chestnut colt by Tredennis-Clare.

5. Grand Fleet. 5 yrs. Bay horse by Bachelor's Double-Dark Dinah.

6. White Squall. 4 yrs. Bay filly by White Eagle-Elm Twig.

Three-year-olds.

7. Royal Welsh, bay colt by St. Amant-Royal Applause.

8. Sea Song, chestnut gelding by PhaleronMiss L. Thrush.

9. Grand Parade, black colt by Orby-Grand Geraldine.

I0. Starshot, chestnut colt by Sunstar-Kitty Muldoon.

I I. Dominion, bay colt by PolymelusOsyrua.

I2. Exford, bay colt by Marcovil-Lamford.

I 3. Trowbridge, brown colt by Bridge of EarnLa Danseuse. 
I4. Powerful, brown colt by PolymelusFlori.

I 5. The Midshipmite, brown colt by StedfastFavorita.

I6. Lancovil, chestnut colt by MarcovilLantana.

17. Lahloo, bay gelding by Santoi-Nydian.

Two-year-olds.

I 8. Great Elm (late Sporty Boy), bay colt by Great Sport-Elm Twig.

19. Bright Folly, brown filly by Black JesterBright.

20. Batusha, bay filly by Bachelor's DoubleKatusha.

21. Sunfringe, bay colt by Sunstar-Gringilla.

22. Brilliant Jester, brown filly by Black JesterLady Brilliant.

23. Glenhattie, bay filly by Glenesky-Lady Harriett.

24. Queen Empress, bay filly by GleneskySceptre.

25. Palatine Kit, bay filly by Prince PalatineKitty.

26. Cantodis, bay colt by Amadis-Miss L. Thrush.

27. Chat Chat, bay gelding by Galloping Simon -Chattan. 
28. Willblend, bay gelding by William RufusPitch Blend.

29. Skyfuse, bay gelding by Glenesky-Melton Fuse.

30. Cutty Sark, chestnut colt by CocyraApparel.

Two or three others came up in the course of the season from Lord Glanely's paddocks ; nothing, however, as will appear in the course of the narrative, of special note.

The colours were soon displayed. On the first day of the season at Lincoln, March 24th, He came out for a race called the Victory Handicap, backed at even money; for though he carried 9 st. the four opposed to him were moderate animals. The start was unprofitable, Lord Zetland's Kroo Boy II. and Mr. Dunkerly's old horse Parrot dead-heating in front of Mr. A. E. Barton's Jack Role. Royal Welsh was also beaten this day in the Welbeck Three-Year-Old Handicap, but he was not expected to win. Lincoln thus yielded nothing, and none of the horses ran later in the week at Liverpool, where six of the fourteen flat races were won by Lord Derby. The black; red, white, and blue belt, was not seen again until Leicester, when Royal Welsh failed in a Three-Year-Old Handicap, as did Lancovil in the Worksop Maiden Plate. The first victory of the season was gained on the second day, the Wigston Plate, which went 
to the home-bred son of Phaleron and Miss L. Thrush.

LEICESTER.

Tuesday, April 8th.

WIGSTON PLATE (Handicap) of $£_{2} 200$, of which second recd. $£$ Io, for 3 yr. olds; entr. $£ 6$, or $£ 3$ if dec. ; 6 fur., straight

(19 ents., viz., 10 at $£ 6$ and 9 at $£ 3-£ 184$.)

Lord Glanely's ch.g. Sea Song, by Phaleron-

Miss L. Thrush, 8 st. $2 \mathrm{lb}$. - - - O. Aldridge I

Sir W. Cooke's Potentilla, 8 st. 4 lb. - - F. Slade 2

Lord Wilton's Off Chance, $* 8$ st. $9 \mathrm{lb}$. - - T. Leader 3

Sir R. W. B. Jardine's Bomb Pin, * 7 st. 4 lb. G. Colling -

Mr. W. H. Dixon's Laundress, * 7 st. 3 lb. - K. Piggott -

* 5 lb. apprentice allowance deducted.

II/8 on Potentilla, 5/1 agst. Laundress, 6/1 Sea Song, 7/1 Off Chance and Bomb Pin. Won by $\frac{3}{4}$ length, same second and third.

The horses were not very busy during the earlier weeks, Sea Song was stopped by his penalty in the Alexandra Handicap at Gatwick on the 9th of April, and the stable was not represented until the Newmarket Craven Meeting, when Glenhattie formed one of the field of twenty-two for the Ashley Plate, a prize for which His Majesty's Dayspring started favourite, to be beaten out of a place by the late Madame Varipati's Gleneskaki. Better things were in store. It was evident that $\mathrm{He}$ could not have given his running at Lincoln. He tried again in the Babraham Plate, sharing favouritism with Mr. R. W. Tilley's Morning Star to whom he was giving $16 \mathrm{lb}$, and he not only won but did so in a canter by six lengths. 
NEWMARKET Craven Meeting. Thursday, April 24th.

BABRAHAM PLATE (Handicap) of $\$ 500$, of which second recd. $£ .50$; entr. $£ 8,3 \mathrm{ft}$., last $1 \frac{1}{2} \mathrm{~m}$. of Cesarewitch Course ( 13 ents. - $f 442$.)

Lord Glanely's b.c. He, by Santoi-She, 4 yrs., 8 st. 7 lb. - - - - - - A. Smith I Mr. R. W. Tilley's Morning Star, 4 yrs., 7 st. $6 \mathrm{lb}$. H. Allsop 2 Lord Wilton's Jack Point, 4 yrs., 8 st. 2 lb. - T. Leader 3 Mr. W. M. Cazelet's Silver Bullet, 4 yrs., 8 st. J. Brennan Mr. J. A. Dunkerley's Parrot, aged, 7 st. 1o lb. P. Jones Mr. Reid Walker's Tom Pepper, 4 yrs., 7 st. 4 lb. J. Shatwell Mr. P. W. Carr's Warwick, 5 yrs., 7 st. 3 lb. - A. Flanagan $7 / 2$ agst. He and Morning Star, 4/I Tom Pepper, II/2 Warwick, 7/1 Silver Bullet, 10/1 Parrot, and 100/8 Jack Point. Won by 6 lengths, same second and third. Shatwell and Flanagan complained that the Starter dispatched the rest of the field when their horses were turned round and walking away from the gate. The Stewards heard the evidence of the jockeys and Starter. The latter admitted that he was to blame because he was paying too much attention to another fretful horse in the race. The Stewards pointed out to the Starter that on no account should the chances of other horses be sacrificed by paying undue attention to an unruly horse.

Exford ran well for the Wood Ditton Stakes. He was not likely to have beaten a really good horse like Manilardo at even weights, and Manilardo won, but Exford finished a neck behind the Duc Decazes's Rapidan, on whom odds were laid, and in the succeeding race, the Severals Stakes, Starshot ran second to Mr. S. B. Joel's Racket, the favourite, Sir George Noble's Clarion a head behind Starshot at even weights. A more important event was impending, K 
the reappearance of Dominion, who came out for the Craven Stakes, the principal item of the Craven Meeting, a race which has fallen to classic winners, Scot Free, the well-named son of MacGregor and Celibacy, Jeddah, Slieve Gallion, Neil Gow, Kennymore, as also Thurio, winner of the Grand Prix, and Morion of the Gold Cup. Dominion was not much fancied, starting at the long price of roo to 7 . He finished a highly respectable third to Buchan and Bruff Bridge, a length and a half and three-quarters of a length being the verdict. This was by no means altogether discouraging, as there was much room for improvement in the colt. For the rest Royal Welsh, a 2 to $I$ chance for the Three-Year-Old Handicap, failed by two heads.

NEWMARKET Craven Meeting. Friday, April 25th, 1919. CRAVEN STAKES of $£_{1}$ o each starter, with $£_{5} 00$ added, of which second recd. $£ 50$, for $3 \mathrm{yr}$. olds; entr. $£ 5 ; \mathrm{R}$. M. (62 ents. $-£ 515$.

Major W. Astor's b.c. Buchan, by Sunstar -Hamoaze, 9 st. $6 \mathrm{lb}$. - - - - J. Brennan I

Sir G. Noble's Bruff Bridge, 9 st. 6 lb. - - J. Childs 2 Lord Glanely's Dominion, 9 st. 6 lb. - - A. Smith 3 Mr. Sol Joel's Polygnotus, 9 st. 6 lb. - - S. Donoghue Sir R. W. B. Jardine's Flower-bed, 8 st. I 3 lb. Wm. Griggs Sir Hedworth Meux's Sir Douglas, 8 st. 13 lb. B. Carslake Mr. W. M. G. Singer's Flying Spear, 8 st. Io lb. V. Smyth Lord Anglesey's Khalifah, 8 st. $5 \mathrm{lb}$. - - A. Whalley II/8 agst. Polygnotus, 5/2 Buchan, 6/I Bruff Bridge, 7/I Sir Douglas, 100/7 Dominion.

Won by $1 \frac{1}{2}$ lengths, $\frac{3}{4}$ length second and third. 
Of the two horses sent to the Epsom Spring Meeting Cutty Sark, ridden by Carslake, a jockey for some reason less successful here than elsewhere, made little show in the Two-Year-Old Westminster Plate, Scatwell, thought to have a fair chance in the City and Suburban, backed at 9 to I, finished unplaced to Lady Queensberry's Royal Bucks, Lord Jersey's Arion, and Admiral of the Fleet Sir Hedworth Meux's Dansellon. Sandown follows Epsom. Royal Welsh's fourth attempt, in the Esher Cup, was abortive, but Sky-rocket won the Guildford Handicap.

SANDOWN PARK Second Spring Meeting. Friday, May 2nd. GUILDFORD HANDICAP of $£_{2} 200$, of which second recd. $£_{20}$, for $4 \mathrm{yr}$. olds and upwards; entr. $£_{4}$, or $£_{\mathrm{I}}$ if dec.; $\mathrm{I} \frac{1}{2} \mathrm{~m}$. ( 13 ents., viz. Io at $£ 4$, and 3 at $£$ I $-£_{1} 176$.)

Lord Glanely's ch.c. Sky-rocket, by Sunstar -Maid of the Mist, 4 yrs., 9 st. $4 \mathrm{lb}$. - A. Smith I Mr. R. Mills' Gloomy Dean, aged, 7 st. - - J. Plant 2 Mr. R. B. Thorburn's New Guinea, 4 yrs., 8 st. 6 lb. Mr. W. Blythe's Sea Voyage, aged, 8 st. - E. Wheatley Mr. G. Barclay's Golden Rule, aged, Io st. 2 lb. J. Clark Mr. A. E. Barton's Leandros, 4 yrs., 9 st. 2 lb. was weighed for by R. Cooper, but the number was withdrawn by permission of the Stewards.

5/4 agst. Golden Rule, II/4 New Guinea, 9/2 Sea Voyage, 6/1 Sky-rocket, IO/I Gloomy Dean. Won by $\frac{3}{4}$ length, 6 lengths second and third.

Proceeding to Newmarket for the First Spring Meeting Lord Glanely had good cause to be satisfied 
with the results of the week. He was one of three starters for the March Stakes, another being Paper Money, now in steady demand for the Derby. These two were meeting at weight for age. The third runner, Polyscope, was not fancied, but to beat Sir Walter Gilbey's colt was calculated to increase the reputation of He. Paper Money stood at evens. He at 2 to I, and Lord Glanely triumphed, after a stirring finish, by half a length.

NEWMARKET First Spring Meeting. Thursday, May 8th. MARCH STAKES of $£ 300$, of which second recd. $£ 30$, by subscription for $f^{6}, 3 \mathrm{ft}$. for $3 \mathrm{yr}$. olds and upwards ; A.F., I $\frac{1}{4} \mathrm{~m} . \quad$ (I7 ents. - -264.$)$

Lord Glanely's b.c. He, by Santoi-She, 4 yrs., 9 st. 4 lb. - - - -

Sir Walter Gilbey's Paper Money, 3 yrs., 7 st.

I2 $\mathrm{lb}$.

A. Smith I

Mr. Sol Joel's Polyscope, 4 yrs., 9 st. - - B. Carslake 3

Even Paper Money, 2/1 agst. He, 4/1 Polyscope. Won by $\frac{1}{2}$ length, bad third.

Royal Welsh at length got home.

NEWMARKET First Spring Meeting. Friday, May 9th. THREE-YEARS-OLD HANDICAP of $£ 400$, of which second recd. $£ 30$; entr. $£ 9,4$ ft. A.F., $1 \frac{1}{4} \mathrm{~m} . \quad\left(22\right.$ ents. $\left.-£_{3} 6 \mathrm{r}.\right)$

Lord Glanely's b.c. Royal Welsh, by St.

Amant-Royal Applause, 8 st. 7 lb. - - A. Smith I

Mr. Sol Joel's Longslip, 7 st. 8 lb. - - S. Donoghue 2

Mr. W. M. G. Singer's Chat Tor, 7 st. 3 lb. - G. Colling 3

Mr. A. E. Barton's Roi Hero, 9 st. - - R. Cooper -

Lord Anglesey's Longdon, 8 st. - - - A. Whalley -

Sir W. Cooke's Helix, 7 st. 10 lb. - - . F. Slade - 
Major J. B. Paget's Flying Duck, 7 st. Io Ib. E. Lancaster Mrs. Howard's Energy, 7 st. 4 lb. (carr. 7 st.

Lord Jersey's Calypso, 7 st. 4 lb. -

G. Hulme

H. Robbins -

9/4 agst. Longslip, 4/I each Royal Welsh and Chat Tor, 7/I Calypso, 8/I Roi Hero, Io/I Flying Duck. Won by $\frac{1}{2}$ length, 6 lengths second and third.

Starshot was second to Knight of the Air for the Ely Plate, and Great Elm took part in the First Spring Two-Year-Old Stakes, not to be seen again; but in the Two Thousand Guineas Dominion must certainly be admitted to have done admirably. By this time The Panther, though he had not been out, had seriously damaged his reputation owing to well-founded reports of temper and trickiness. Odds of Io to I were to be had about him by those who cared to take what was admittedly a heavy risk. Of the two Manton colts Lord Basil was now so much preferred to Buchan that their prices were 2 to $\mathrm{I}$ and IOO to 8 respectively, Stefan the Great sharing Lord Basil's eminence. Tangiers, Iron Hand and Bruff Bridge found casual supporters; against Dominion 100 to 6 was forthcoming. The race was to end in a surprise. Stefan the Great ran very badly, and was never seen again on a racecourse. Mr. H. S. Persse's skilful patching did not avail. Lord Basil could or would do nothing. The Panther, for once amenable, ran straight and won by a neck from Buchan, the Manton colt having much difficulty in shaking off Dominion, who finished three 
parts of a length behind him, thus beaten exactly one length by the winner.

NEWMARKET First Spring Meeting.

Wednesday, May 7 th, 1919.

2000 GUINEAS STAKES of $f_{f} 100$ each, h. ft. for entire colts and fillies, foaled in 1916 ; colts 9 st., fillies 8 st. $9 \mathrm{lb}$. ; second recd. $£ 400$ and third $£ 200$ out of stakes. R.M. (99 ents. $-£ 4850$.)

Sir A. Black's br.c. The Panther, by Tracery

-Countess Zia, 9 st.

Major W. Astor's b.c. Buchan, 9 st.

Lord Glanely's b.c. Dominion, 9 st.

Sir G. Noble's b.c. Bruff Bridge, 9 st.

Major W. Astor's br.c. Lord Basil, 9 st.

Sir A. Bailey's b.c. Wilson, 9 st.

Mr. T. Martin's br.c. African Star, 9 st.-

Sir W. Nelson's b.c. Tangiers, 9 st.
R. Cooper I

V. Smyth 2

- A. Smith 3

- J. Childs 4

- J. Brennan -

- F. Fox -

- M. Wing -

- S. Donoghue -

Mr. Lionel Robinson's gr.c. Stefan the Great,

9 st. - - - - - - - - B. Carslake -

Mr. H. W. Rudd's ch.c. Laurentian, 9 st. - E. Piper Mrs. H. Whitworth's ch.c. Iron Hand, 9 st. - J. H. Martin Mr. F. Willey's ch.c. Knight of Blyth, 9 st. - A. Whalley -

2/I agst. Stefan the Great and Lord Basil, 10/I The Panther, 100/9 Tangiers, 100/8 Buchan and Iron Hand, 100/7 Bruff Bridge, $100 / 6$ Dominion.

Won by a neck, $\frac{3}{4}$ length second and third.

In the One 'Thousand Guineas Lord Glanely's Lady Juliet started with no great hope of success. Her price, Io to I, suggested that she was considered to be just among the possibles, and Sir Edward Hulton's Roseway, expected to win, did so; while Mr. Lionel Brassey's Britannia, reckoned as likely to get a place, was second. 78 
The reason why Dominion's forward position caused so much satisfaction was that Grand Parade had been showing himself distinctly the better of the two, and others who had been among their most formidable opponents were, as will have been gathered, gradually clearing out of the way. There was still, indeed, The Panther, for after the Two Thousand Guineas not a few of his former friends returned to their allegiance. Still for obvious reasons doubts about him existed. Galloper Light, who incidentally had not distinguished himself in the City and Suburban, was not engaged in the Derby. As stated, Stefan the Great was no longer a source of danger. There were adverse rumours about Lord Basil, and that $\mathrm{He}$ had defeated Paper Money afforded a line pointing to the probability that Grand Parade would beat the son of Greenbank and Epping Rose.

One of the most disappointing animals in the stable was Grand Fleet. Handicappers had a tendency to overrate him, for he generally had what appeared to be a betting chance, and without winning-he only scored once during the season-he ran forward enough to secure him a following next time he appeared. He came out for the seven furlong Victoria Cup at Hurst Park, backed at 3 to I, Diadem at 2 to I. This charming mare was in fact regarded by the majority as a good thing; but for once she ran a very poor race, and at any rate Grand Fleet beat her, finishing third 
to Mr. W. H. Savill's Carados and Mr. Z. G. Michalinos's Golly Eyes, the verdict a length and a head. Nothing was sent to Chester, but later in the week Lord Glanely, who is a Steward of Kempton Park, supported that fixture, and did so remuneratively. Though Dominion could not be described as a five furlong horse he was backed at 4 to I for the Stewards' Handicap over that distance, carrying 7 st. Io $1 \mathrm{~b}$. Syndrian, a 9 to 4 chance, missing it by a head-that of Major Holliday's Monte Faro-and Grand Fleet tried again in the Jubilee, for which he at least did better than the roo to 6 at which he started seemed to promise. Lord Jersey's Arion ran away with the race, and for second place Mr. F. Hardy's Not Much beat Grand Fleet by little more than a length.

Every win counts however it is gained, and Skyrocket is to be credited with the Shelford Plate at the Newmarket Second Spring Meeting. Odds of 25 to I were laid on him, for he had only a solitary opponent, a shockingly bad filly called Jacana, who did not get off.

NEWMARKET Second Spring Meeting. Wednesday, May 2 Ist. SHELFORD PLATE of $f_{2} 200$, of which second recd. $£_{20}$, for

3 yr. olds and upwards; entr. $f 3 ; 2$ middles miles of B.C.

(9 ents. - -177.$)$

Lord Glanely's ch.c. Sky-rocket, by Sunstar

-Maid of the Mist, 4 yrs., 8 st. (8 st. I 2 lb.) A. Smith I Mr. E. Moore's Jacana, 3 yrs., 6 st. I I lb. - J. Tilbury 2 25/1 on Sky-rocket. Won by a distance; Jacana swerved at the start and lost ground. 
An hour later came the Newmarket Stakes, for which Dominion was saddled, one of five, including Lord Basil. The latter was again in high favour, in fact his success was deemed so certain that he started at I I to 4 on. But if the Manton colt had staunch admirers there were also those who did not in the least believe in him. The evening before the race Captain Lionel Montagu was a fellow guest with me at dinner at a friend's house, and his opinion of Lord Basil was so contemptuous that though it was evident the colt would start with long odds laid on him my friend offered an even pony that he did not win, a bet I gladly accepted. Captain Montagu's Old Bill was one of the five runners and finished second, Lord Basil third, Dominion backed at 8 to I securing the prize, and doing so in a canter by nearly half a dozen lengths.

NEWMARKET Second Spring Meeting. Wednesday, May 2 1st.

NEWMARKET STAKES of $f .30$ each, $10 \mathrm{ft}$. (to fund) if dec., with $£ 1000$ added, of which second recd. $£ 100$, and third f50, for 3 yr. olds; A.F., $1 \frac{1}{4} \mathrm{~m}$. $(64$ ents., ft. dec. for $23-\{2050$.)

Lord Glanely's b.c. Dominion, by Polymelus

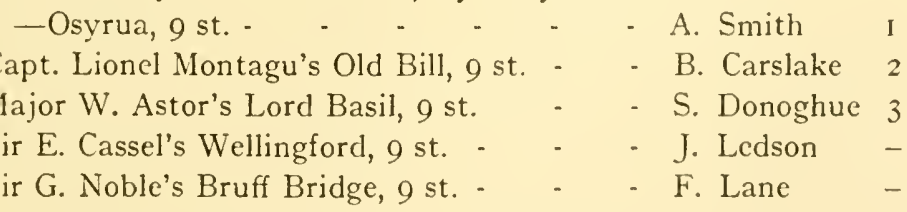

11/4 on Lord Basil, 6/1 agst. Bruff Bridge, 8/1 Dominion. Won by 5 lengths, 2 lengths second and third.

L 
Epsom was now at hand, the majority of backers by this time staunch in the conviction that The Panther would win the Derby. Winners of the Two Thousand Guineas have been accustomed to do so. Accepting the substitute Derby over the Suffolk Stakes course at Newmarket as the real thing, both classics had of recent years been won frequently by the same horse, Gainsborough in I 918, Gay Crusader 1917, Pommern I9 16, Sunstar I9I I, Minoru I909, St. Amant I 904, Rock Sand I 903, Diamond Jubilee I 900 , Flying Fox I 899, Galtee More I 897, Ladas I 894, Isinglass I 893, Common r89 I, Ayrshire r888, Ormonde I886; then Paradox in 1885 was beaten a short head, and Galliard in 1883 had just missed it the year after Shotover had carried on the tradition. This was encouraging for those who placed faith in The Panther, admittedly a really good-looking colt, and it was protested that in his case appearances were not deceptive. He maintained his favouritism in the face of the sceptics, notwithstanding that on his arrival at Epsom he had shown temper, translated by his admirers into " a little wilfulness the result of high courage." It is thus that men credit what they are anxious to believe.

Meanwhile misfortune, or what seemed to be so, was affecting Barling's stable. One morning Grand Parade showed symptoms of lameness. His progress had been in all respects satisfactory until a few days 
before the great event, and now a horrible suspicion arose that it might be impossible to get him to the post. What sort of a colt Grand Parade really was may be judged from the fact that a month before the Derby he had been asked to give $\mathrm{He}$ the year and $3 \mathrm{lb}$., a task he had accomplished with ease. As will presently be seen He won the Coronation Cup from Galloper Light at weight for age, and Mr. A. de Rothschild's colt was good enough to win the Grand Prix. The fear was the more exasperating because through Dominion, who as will have been seen was able to furnish a clear line to the three-year-old form, Grand Parade could also be made out to possess a superlative chance; but the necessary stoppage of work seemed likely to prove fatal, and it consequently appeared that if Lord Glanely was to win the Derby it must be by the aid of his second string.

The scare to some extent abated. A few days' cessation from hard work had a beneficial effect. On the morning of the race Grand Parade was fit and well enough to run without much fear of his breaking down. Whether the stoppage had so affected the colt as to bring him to the level of Dominion nothing but the race could show. Arthur Smith, the stable jockey, was allowed his choice of the pair. Presumably he had been able to form a judgment as to which had the better chance, and without hesitation he chose 
Dominion. Had all gone smoothly with both colts he would of course have been upon the other, and when the news spread the market naturally reflected his decision. Grand Parade went out to 33 to I, Dominion shortened to I00 to 9. There were only three better favourites than the last named, The Panther, against whom many bookmakers would not lay a fraction over even money though he is returned at 6 to 5, with Buchan-for Lord Basil had finally dropped out-and Paper Money at 7 to I. Smith on Dominion wore the first colours, Templeman on Grand Parade had a distinguishing cap. The two were running strictly on their merits, but, as indicated, the better of them was less fit and forward than the other.

A curious circumstance in connection with the Derby of 1919 is that it came near to being started in the old-fashioned way by flag. Something went wrong with the electric release of the gate shortly after the race and the last three events on the card which followed the Derby were started as Derbies used to be. Thirteen went to the post, the same number as in the previous year, one more than in I 9 I 7 , and it may be added seventeen fewer than when Durbar II. won in I9I4. Backers of The Panther had cause for alarm. He evinced the strongest objection to joining his horses. If it were a case of high courage his courage was dangerously high, and it may be at once said that at no period of the race did 



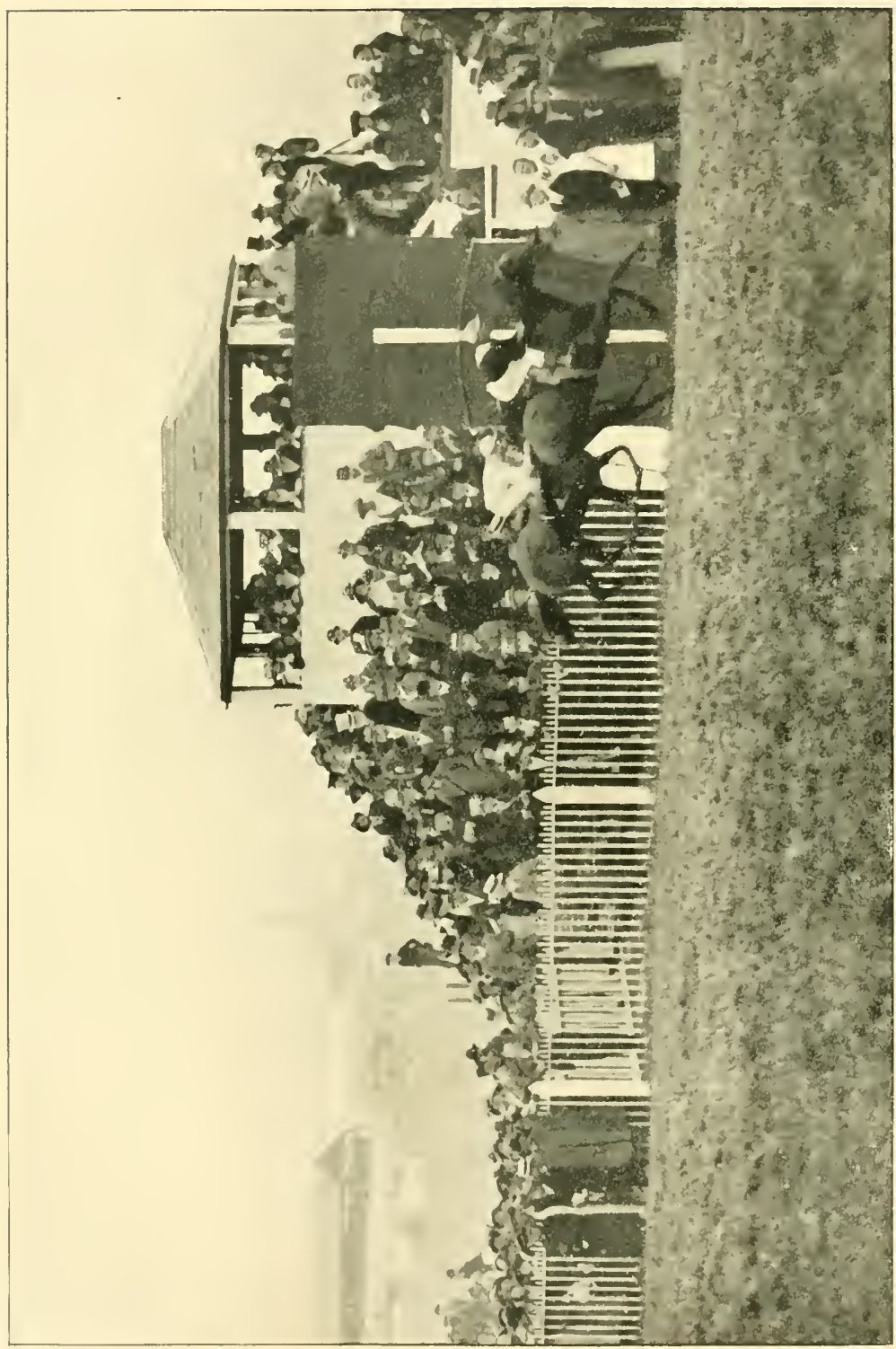

告 
he threaten danger. The course was in very bad condition, with little herbage and patches of adamantine hardness. An excuse is made for Paper Money that he put his foot in a hole, but he ran remarkably well nevertheless, so much so that at the old landmark which used to be spoken of as The Bell his backers were beginning to proclaim his triumph. At the critical moment, however, it became evident that the bearer of Sir Walter Gilbey's chocolate and yellow stripe, scarlet cap, could not compete with Lord Astor's light blue, pink sash and cap, or with Lord Glanely's more sombre jacket. Sir Hedworth Meux's sea-green, turquoise cap, on Sir Douglas, had momentarily raised some hope, but in the last hundred and fifty yards the issue had come to be between Grand Parade and Buchan. It was natural to feel apprehensive that the lack of his winding-up gallops and of incidental work might tell upon Grand Parade in the last few strides; but he stuck gallantly to his task and holding his own passed the post half-a-length in front of Buchan. Brennan on Lord Astor's colt was criticised for his riding of the finish, the critics however omitting to state in what respect he was wanting, and as regards the race being won by the best horse, when it is considered that Grand Parade was distinctly short of work, Buchan in the height of condition, the state of the case is obvious. Thus within a period of little over ten years Lord Glanely succeeded 
in winning the Derby, an achievement which many owners have vainly striven all their lives to accomplish.

EPSOM Summer Meeting.

Wednesday, June 4th.

DERBY STAKES of $£ 6500$ (including $£ 500$ for nominator of winner) with $£ 400$ for second and $£ 200$ for third, by subscription of $£ 50$ each, h. ft. or $£ 5$ if dec., for $3 \mathrm{yr}$. olds, entire colts and fillies; colts 9 st., fillies 8 st. $9 \mathrm{lb}$., about $1 \frac{1}{2} \mathrm{~m}$. (215 ents., viz. 13 at $£ 50,132$ at $£ 25$, and 70 at $£ 5-£ 6450$.)

Lord Glanely's bl.c. Grand Parade, by Orby

-Grand Geraldine, 9 st. - - - F. Templeman I

Major W. Astor's b.c. Buchan, 9 st. - - J. Brennan 2

Sir Walter Gilbey's b. or br.c. Paper Money,

9 st. - - - $\quad$ - $\quad$ - $\quad$ S. Donoghue 3

Sir Hedworth Meux's b.c. Sir Douglas,

9 st. - - - - - - - G. Hulme 4

Lady Torrington's b. or br.c. All alone, 9 st.

Mr. F. Willey's b.c. Bay of Naples, 9 st. - A. Whalley -

Lord Glanely's b.c. Dominion, 9 st. - - A. Smith

Mr. C. T. Garland's br.c. Milton, 9 st. - - G. Colling -

Mr. J. A. de Rothschild's ch.c. Roamer,

9 st. - - - - - - - J. Childs

Sir W. Nelson's b.c. Tangiers, 9 st. - - E. Piper

Sir A. Black's br.c. The Panther, 9 st. - R. Cooper -

Capt. Lionel Montagu's b.c. White Heat,

9 st. - - - - - - - H. Jelliss

Sir G. Murray's br.c. Coriolanus, 9 st. - B. Carslake -

6/5 agst. The Panther, 7/1 Buchan and Paper Money, 100/9 Dominion, 20/I Milton, 25/1 All Alone, 33/1 Grand Parade, 40/1 Tangiers, 50/1 each Sir Douglas, Bay of Naples, Roamer, and Coriolanus, 100/1 White Heat. Won by $\frac{1}{2}$ length, 2 lengths second and third; Coriolanus whipped round at the start and lost ground. 


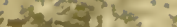

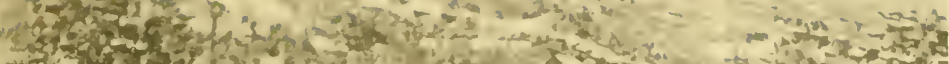

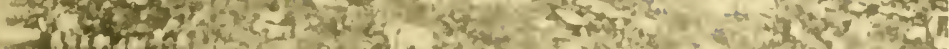

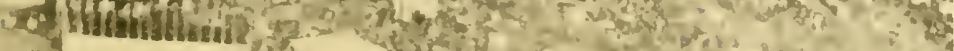

$\therefore 3$ a d a

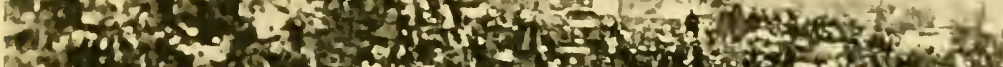

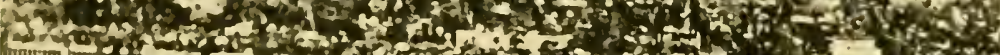

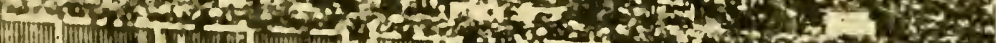

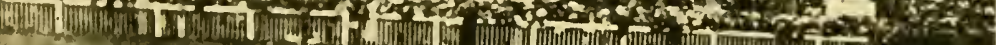
so - 2.

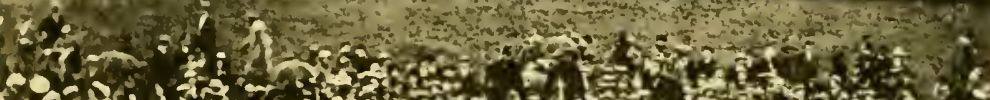

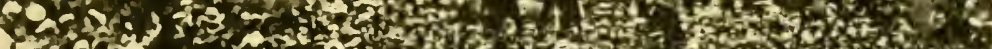

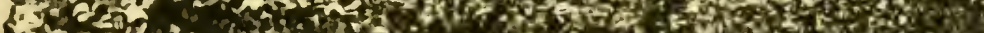

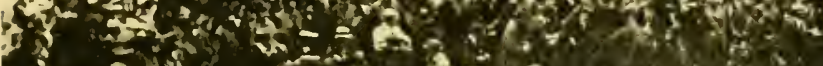

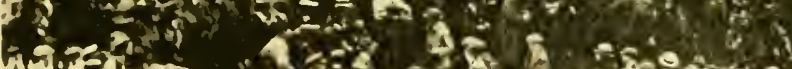

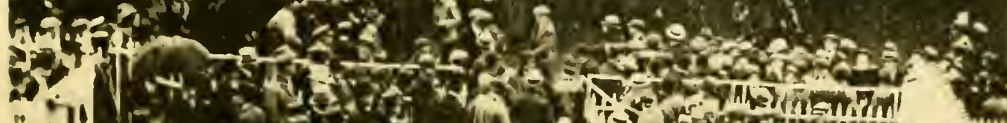
(1)

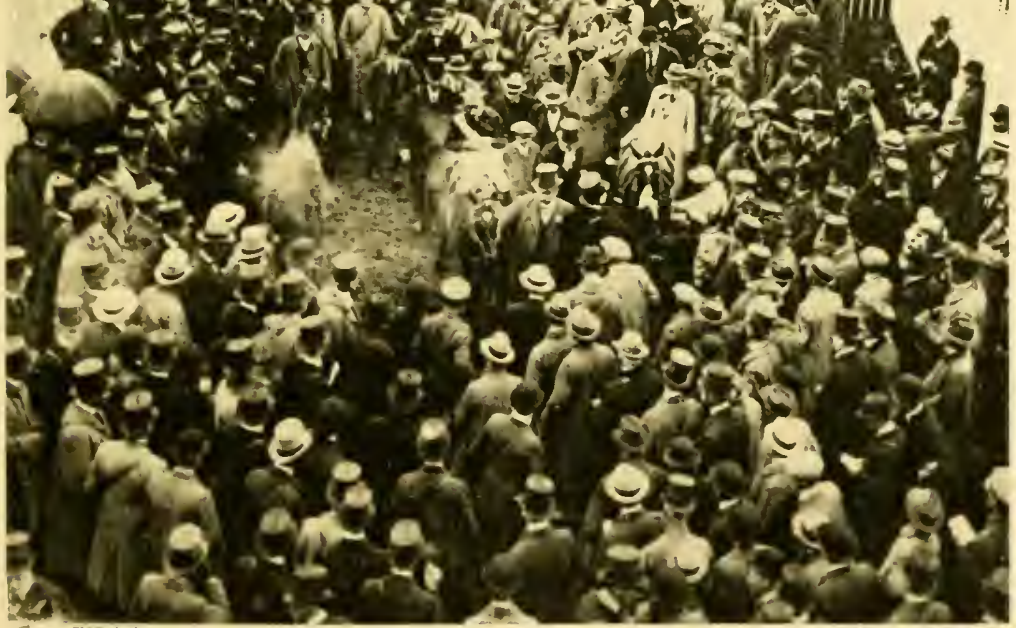
hateritingauch

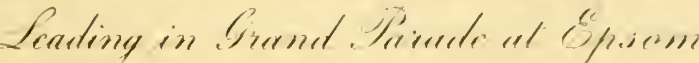



This was not the only notable win at the meeting. He had been sent for the Coronation Cup, which has such a brilliant list of winners-Zinfandel, Pretty Polly (twice), The White Knight (twice), Sir Martin, Lemberg, Stedfast and Prince Palatine. Both the other starters were well fancied, for though no more than even money could be had about He, Galloper Light was backed at 5 to 2, Dansellon at 3 to I. It was a very near thing between the couple first named, He defeating the three-year-old by no more than a head, the margin by which, it may be incidentally remarked, Galloper Light had beaten Tangiers-the winner giving $8 \mathrm{lb}$.- for the Payne Stakes. This was all to the credit of $\mathrm{He}$.

EPSOM Summer Meeting. Thursday, June 5 th. CORONATION CUP, a Gold Cup, value $£ 200$, and $£$ IOOO in specie, added to a Sweepstakes of $f_{20}$ each, or $f_{5} 5$ if dec., with $£ 100$ added for second and $£ 50$ for third, for $3 \mathrm{yr}$. olds and upwards; Derby Course about $1 \frac{1}{2} \mathrm{~m}$. (22 ents., viz. I7 at $£ 20$ and 5 at $£ 5-£$ I 545.)

Lord Glanely's b.c. He, by Santoi-She, 4 yrs., 8 st. 7 lb.

A. Smith I Mr. A. de Rothschild's Galloper Light, 3 yrs.,

7 st. 7 lb. - - - - - -

Sir Hedworth Meux's Dansellon, 5 yrs., 9 st.

6 lb. - - - - - - - B. Carslake 3

Evens $\mathrm{He}, 5 / 2$ agst. Galloper Light, 3/I Dansellon. Won by a head, 4 lengths second and third.

$\mathrm{He}$ it will be seen was worthily qualifying for the stud, and it appeared all the more strange that he 87 
should have been beaten by moderate animals at Lincoln.

The Ascot Meeting was to be for ever memorable in racing history, for research shows that there is no precedent for Lord Glanely's achievement of winning seven races-exactly one quarter of the entire programme. Grand Parade, not materially the worse for his Epsom race, was one of eleven horses sent to run, two of whom began by misses. Mighty Power, the home-bred son of Radium and The Waif, was, it gradually became plain, rather out of his class. in the Coventry Stakes, which the roguish Sarchedon, I 5 to 8 on, won from Poltava, 5 to 2, an objection, which was overruled, following the race. Royal Welsh did much better in the Gold Vase, being beaten no more than a length by the Duke of Portland's Silonyx, behind him amongst others Queen's Square, a good mare when in the humour which was not always, Our Stephen, who was to win the Chester Cup next season, and Perion. But the third attempt was fortunate, Dominion giving proof of his ability to stay by winning the Prince of Wales' Stakes, the distance a mile and five furlongs. If the opposition was not strong he was giving two of the other three $9 \mathrm{lb}$. and the fourth I $6 \mathrm{lb}$. 
ASCOT HEATH.

Tuesday, June I 7 th.

PRINCE OF WALES' STAKES of $£ 50$ each, h. ft., with $£ 500$ added, of which second recd. $£ 200$, and third $£ 100$, for $3 \mathrm{yr}$. olds; New Course, about I m. 5 fur. (46 ents. $-£$ I 400 .)

Lord Glanely's b.c. Dominion, by Polymelus

-Osyrua, 9 st. 5 lb. - - - - - A. Smith I

Mr. J. Buchanan's Splendid Spur, 8 st. Io lb. J. H. Martin 2 Sir G. Murray's Coriolanus, 8 st. Io lb. - - B. Carslake 3 Sir E. Hulton's Avatar, 8 st. 3 lb. - - V. Smyth -

6/5 on Avatar, 2/1 agst. Dominion, 6/I Coriolanus, 10/1 Splendid Spur. Won by $1 \frac{1}{2}$ lengths, 2 lengths second and third.

For the Churchill Stakes He frightened away the opposition, and earned the respectable sum of $£_{1} 275$ by the simple process of walking over.

ASCOT HEATH.

Tuesday, June I7th.

CHURCHILL STAKES (formerly the third year of the Triennial

Stakes) of $£$ Io each, h. ft., with $£$ Iooo added, for 4 yr. olds,

$2 \mathrm{~m}$. (56 ents. - $£ 1275$.

Lord Glanely's b.c. He, by Santoi-She, 9 st.

$3 \mathrm{lb}$. walked over

A. Smith

Leaving off with a victory on the Tuesday, Lord Glanely led off with another on the Wednesday, Skyrocket dead-heating with Sir Berkeley for the Visitors' Handicap, the distance here the mile and a half over which Sir Berkeley was so formidable; and Skyrocket's superiority was demonstrated by the fact that he was giving the other $8 \mathrm{lb}$., both four-year-olds, so it may certainly be said that the running stamped the winner as a good colt. 
ASCOT HEATH.

Wednesday, June I8th.

VISITORS' HANDICAP of $£$ I 5 each, $5 \mathrm{ft}$., with $£ 300$ added for winner and $£ 50$ for second ; third saved stake ; Swinley

Course, $\mathrm{I} \frac{1}{2} \mathrm{~m}$. (24 ents. $-£ 430$.)

Lord Glanely's ch.c. Sky-rocket, by Sunstar

-Maid of the Mist, 4 yrs., 8 st. 5 lb. - A. Smith o

Duke of Portland's b.c. Sir Berkeley, by

Sunstar-La Roche, 4 yrs., 7 st. I I lb. - V. Smyth o

Lord Wilton's Jack Point, 4 yrs., 8 st. 2 lb. - W. Earl 3

Capt. Lionel Montagu's Helion, 4 yrs., 7 st.

$7 \mathrm{lb}$.

- S. Donoghue -

5/4 agst. Sir Berkeley, 5/2 Helion, 5/I Sky-rocket, 6/ I Jack Point. A dead heat, third beaten three lengths. Stakes divided.

Grand Fleet with 8 st. 5 lb. failed in the Hunt Cup, won by that extraordinarily good horse Irish Elegance, and Starshot, backed at 3 to $\mathrm{r}$, ran behind His Majesty's Viceroy in the Waterford Stakes. Viceroy when inclined to gallop was well able to do so, but he was distinctly a horse of moods. "No vice about him-except in his name you know," Lord Marcus had observed to me when speaking of the colt's disposition just before he came out for the first time as a two-year-old at Newmarket.

Wednesday's gains were therefore modest, Old Bill, however, paying indirect tribute to Dominion by winning the Ascot Derby; but Thursday was to add to the spoils. Second on the card came the Granville Stakes for Two-Year-Olds and Three-Year-Olds, contested by a trio of the latter age. Iron Hand 
belonging to the keen lady owner Mrs. Whitworth, who unhappily did not survive the season, was booked as a good thing, 7 to 4 being laid on him, but he was last of the three, Lord Glanely's home-bred Lady Juliet winning by four lengths from a stranger in Mr. W. M. Cazalet's The Sphinx.

ASCOT HEATH.

Thursday, June igth.

GRANVILLE STAKES of $£ 15$ each, $10 \mathrm{ft}$, with $£ 300$ added, of which second recd. $£ 50$, for 2 and $3 \mathrm{yr}$. olds; 5 fur. $(50$ ents. $-£ 750$.)

Lord Glanely's br.f. Lady Juliet, by Mercutio

-Lady Fowler, 3 yrs., 8 st. II lb. - - F. Slade I

Mr. W. M. Cazalet's The Sphinx, 3 yrs., 8 st.

I l lb. - - - - - J. Childs 2

Mrs. H. Whitworth's Iron Hand, 3 yrs., 9 st. S. Donoghue 3

7/4 on Iron Hand, II/4 agst. Lady Juliet, 6/1 The Sphinx. Won by 4 lengths, $1 \frac{1}{2}$ lengths second and third.

He was beaten in the Gold Cup, which, however, was a chapter of accidents. $\mathrm{He}$ had a very stormy passage, being interfered with badly. The race ended in a fight between By Jingo! and Air Raid, the former, backed at 3 to $\mathrm{I}$, having three-quarters of a length the better of the Manton colt on whom odds of 6 to 5 were laid, $\mathrm{He}$ not quite such a good favourite as the winner.

ASCOT HEATH.

Thursday, June 19th, 1919.

GOLD CUP value $£ 500$, with $£ 2000$ in specie, added to a Sweepstakes of $£ 20$ each, h. ft., of which second recd. $£ 300$ and third $£ 100$, for entire colts and fillies, 3 yr. olds 
and upwards; $2 \frac{1}{2} \mathrm{~m}$., starting at Cup Post and going once round. (34 ents. $-f_{2} 460$.)

Mr. W. T. de Pledge's ch.h. By Jingo, by

Aquascutum-Minnesota, 5 yrs., 9 st. $4 \mathrm{lb}$. Mr. W. M. Cazalet's Air Raid, 4 yrs., 9 st. - S. Donoghue 2 Mr. J. A. de Rothschild's Roamer, 3 yrs., 7 st.

7 lb. - - - - - - - - V. Smyth 3 Lord Glanely's He, 4 yrs., 9 st. - - - A. Smith -

$6 / 5$ on Air Raid, 3/I agst. By Jingo, 7/2 He, 20/1 Roamer. Won by $\frac{3}{4}$ length, 6 lengths second and third.

The Cup, however, was sandwiched in between two of Lord Glanely's successes, for Grand Parade, reproduced for the St. James's Palace Stakes, scored by three parts of a length, the odds on him returned at 4 to I, though I remember that more than this was laid. There can be little question that Grand Parade was not at his best; he could not have been so, for he had some trouble in shaking off his rival, Lord Herbert Vane-Tempest's Glanmerin, and though this was a colt of no small capacity he would surely have been unable to make any impression on Grand Parade at even weights had the latter been himself. It may be suspected that he had not recovered entirely from the mishap or indisposition which stopped him before the Derby.

ASCOT HEATH.

Thursday, June igth.

ST. JAMES' PALACE STAKES of $£$ IOO each, h. $\mathrm{ft}$., or $£ 3$ if dec., with $£ 300$ added, of which second recd. $£ 300$, for 



$$
M
$$


3 yr. olds; Old Mile. (57 ents., viz. 2 at $£ 100,33$ at $£ 50$, and 22 at $£ 3-£ 18$ I6.)

Lord Glanely's bl.c. Grand Parade, by Orby

-Grand Geraldine, 9 st. - - - A. Smith I

Lord H. Vane-Tempest's Glanmerin, 9 st. - C. Foy 2

$4 / 1$ to Grand Parade. Won by $\frac{3}{4}$ length.

Special interest attached to the Windsor Castle Stakes on Friday, for a very neat little daughter of Black Jester and Bright, called Bright Folly, was to make her first appearance. Two others were more fancied and one other equally so. Lord Dewar's Sunny Moya just had the call of Mr. Walter Raphael's Lomelie, a filly of whom her owner had formed a very high opinion. When I went over his stable in the Spring I was told that Lomelie was quite the equal of her owner's good colts Allenby and Poltava; but she had a soft strain and would not run her races out. The Windsor Castle Stakes would evidently require winning, for Mr. C. T. Garland's Woodrow had recently taken a race, and there was money for Most Beautiful, who however was left at the post. Bright Folly won by a length from the favourite.

ASCOT HEATH.

Friday, June 20th.

WINDSOR CASTLE STAKES of $£ 15$ each, $5 \mathrm{ft}$., with $£ 300$ added, of which second recd. $10 \%$, for 2 yr. olds; 5 fur. (IOI ents.-f8I7 IOs. od.)

Lord Glanely's b.f. Bright Folly, by Black Jester-Bright, 8 st. 7 b

Lord Dewar's Sunny Moya, 8 st. 7 lb.

- A. Smith I

- S. Donoghue 2 
Mr. C. T. Garland's Woodrow, 9 st. 3 lb - G. Colling 3 Mrs. H. Cunliffe-Owen's Mount Royal, 8 st.

Io lb. - - - - - - . F. Leach

Mr. Sol Jocl's Polyact, 8 st. Io lb. - - J. Childs

Sir Alan Johnstone's Parisian Diamond,

8 st. Io lb. - - . - . .

Capt. Giles Loder's Svengali, 8 st. Io lb. - J. H. Martin Mrs. S. Van den Bergh's Swift Flight, 8 st.

Io lb. - - - - - - - B. Carslake -

Mr. A. Bendon's Most Beautiful, 8 st. 7 lb. - F. Lane -

Sir E. Cassel's Indenture, 8 st. 7 lb. - - J. Ledson -

Mr. W. Raphael's Lomelie, 8 st. 7 lb. - F. Slade -

Duke of Westminster's Princess Joan, 8 st.

$7 \mathrm{lb}$ - - - - - - - F. Templeman -

100/30 agst. Sunny Moya, 7/2 Lomelie, 5/1 Mount Royal and Bright Folly, I0/1 Woodrow, 100/8 Most Beautiful. Won by a length, 4 lengths between second and third; Most Beautiful would not go up to the tapes and was ignored and left at the post.

Half-an-hour later Lord Glanely carried off his seventh race at the meeting, the Wokingham Stakes by the aid of Scatwell. The colt was freely backed, almost as good a favourite as Mr. J. A. de Rothschild's sensational Cambridgeshire winner Brigand. So the record of Ascot, I9I9 closed. The money part of the business was not regarded as the most important, though it may be noted that the seven races were worth, as was to be expected at the Royal Meeting, rather over an average of $£$ IO00 each, $£ 7233$ Ios. altogether. 



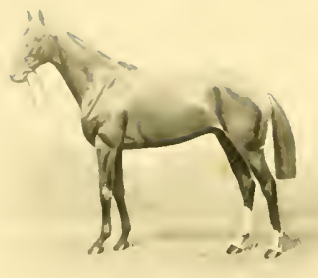

Fratuedl.

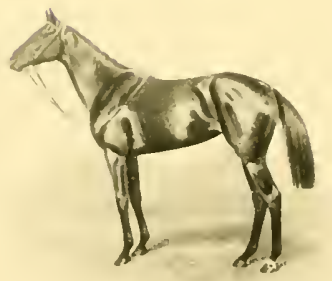

tirely fuliet:
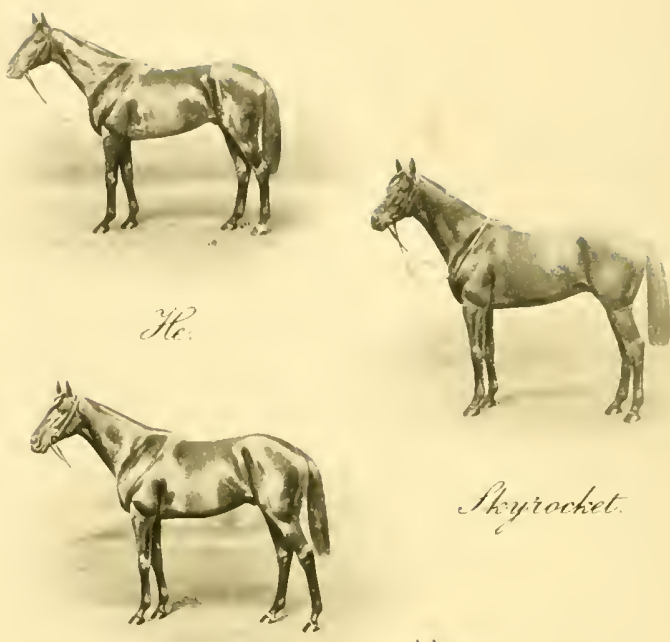

Thyortiet

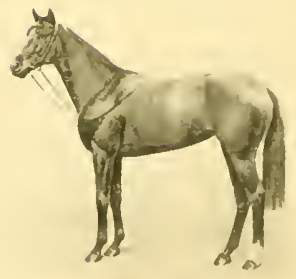

Pright Filly.

Q7)minim.

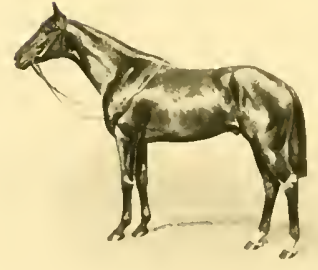

Ulater L 'Gils. C'a

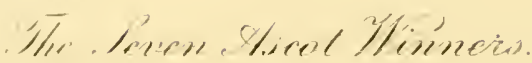


ASCOT HEATH.

Friday, June 20th.

WOKINGHAM STAKES (Handicap) of $£ 15$ each, $5 \mathrm{ft}$., with $£ 500$ added, of which second recd. $£ 100 ; 6$ fur. on Hunt Cup Course. (50 ents. $-£ 745$.)

Lord Glanely's ch.c. Scatwell, by Marcovil -Cheshire Cat, 4 yrs., 7 st. I I lb. - -

Sir E. Cassel's Viviani, 4 yrs., 7 st. 4 lb.

(car. 7 st. 6) - - $\quad-\quad$ - -

Mr. Z. G. Michalinos' Golly-Eyes, 5 yrs.,

7 st. 5 lb. (car. 7 st. 6 lb.) - - - F. Fox

F. Slade

I

Lord Jersey's Fressia, 4 yrs., 8 st. 5 lb.

(car. 8 st. 6 lb.) - - - - -

Sir E. Hulton's Violinist, 4 yrs., 7 st. to lb. - V. Smyth -

Major L. B. Holliday's Monte Faro, 3 yrs.,

7 st. Io lb. - - - - - .

Mr. J. A. de Rothschild's Brigand, 5 yrs.,

7 st. 9 lb. - - - - - .

Mr. Sol Joel's Kashmir, 4 yrs., 7 st. 6 lb. -

Mr. R. J. Farquharson's Ramboda, 3 yrs.,

7 st. 5 lb. - - - - - -

Lord Derby's Glaciale, 3 yrs., 6 st. I I lb. J. Ledson 2

F. Fox 3

F. Templeman -

W. Balding -

S. Donoghue -

R. Cooper -

G. Hulme -

Mr. E. J. Caldicott's Bayodee, 6 yrs., 6 st.

4 lb. (car. 6 st. 5 lb.) - - - - A. Balding -

7/2 agst. Brigand, 4/I Scatwell, 9/2 Golly-Eyes, 8/I Violinist, 100/9 Viviani, 100/8 Monte Faro and Kashmir, I00/7 Ramboda. Won by $I \frac{1}{2}$ lengths, 2 lengths second and third.

It is perhaps hardly worth while to write that Quantum ran at Birmingham behind Lord Derby's Princess Margaret, then known as the Spean Bridge filly. Lord Glanely however took an interest in his colt, he being home-bred, a son of Quantock and Lady Fowler, half-brother therefore to Lady Juliet. $\mathrm{He}$ 
was cut soon after, an operation which had no good results. A short period of quietness ensued, but at the Newmarket First July the stable was again in evidence. Exford took one of the Apprentice Plates in which he not seldom performed.

NEWMARKET First July Meeting.

Tuesday, July 2nd.

VISITORS' (APPRENTICE) PLATE (Handicap) of $f_{150}$, of which second recd. $£ 10$; winners extra; entr. $f 3$, or $£_{1}$ for horses not trained at Newmarket; Beaufort Stakes Course, 7 fur. (I 8 ents.- $£ 137$. )

Apprentices were not allowed to carry whips in this race. Lord Glanely's b.c. Exford, by Marcovil-

Lamford, 3 yrs., 7 st. 7 lb. - - - T. May I Lord Stanley's Devonport, 4 yrs., 6 st. 5 lb. - G. Formby 2 Mr. P. Nelke's Polichinelle, 3 yrs., 6 st. (inc.

7 lb. ex.) - - - - - - H. Wheatley 3 Lord Wilton's Atrocity, 3 yrs., 7 st. 2 lb. - A. Garnett Lord Derby's Mrs. Jawleyford, 4 yrs., 6 st. I $2 \mathrm{lb}$.

Mr. J. L. Ainsworth's Abiad, 4 yrs., 6 st. $10 \mathrm{lb}$. Mr. S. H. Gollan's Bima, 3 yrs., 6 st. 4 lb. Mr. G. A. Egerton's My Patsey, 4 yrs., 5 st.

I3 lb. (car. 6 st.) - - - -

Io lb. - - - - - - . Mr. E. C. B. Portman's Torchlet, 3 yrs., 5 st.

$7 \mathrm{lb}$.

F. Huxley -

L. Ager

J. Tilbury -

2/1 agst. Polichinelle, 6/1 Exford and Atrocity, 7/1 Mrs. Jawleyford and My Patsey. Won by a length, $I \frac{1}{2}$ lengths second and third; Abiad dwelt at the start and lost ground.

Scatwell also beat the King's Vain Dream in the Waterbeach Plate. 
NEWMARKET First July Meeting.

Friday, July 4th.

WATERBEACH HANDICAP of $£ 300$, of which second recd. $£ 30$; entr. $£ 5$; last 6 furlongs of B.M. (16 ents. $-£_{265}$.)

Lord Glanely's ch.c. Scatwell, by Marcovil-

Cheshire Cat, 4 yrs., 9 st. I lb. -
His Majesty's Vain Dream, 3 yrs., 7 st. 5 lb.

(car. 7 st. 6 lb.) - - - - .

Lord Ellesmere's Trespasser, 3 yrs., 7 st. 2 lb.

(car. 7 st. $5 \mathrm{lb}$.)

A. Smith I

S. Donoghue 2

Mr. H. Cunliffe Owen's King Sol, 5 yrs., 8 st.

$2 \mathrm{lb}$.

Mr. Sol Joel's Cutaway, 4 yrs., 7 st. 7 lb. - F. Fox

Mr. W. H. Dixon's Linton, 3 yrs., 6 st. $12 \mathrm{lb}$. W. Balding Lord Anglesey's Khalifa, 3 yrs., 6 st. 4 lb. - J. Leach -

II/8 agst. Scatwell, 5/2 Vain Dream, 6/1 Cutaway, 7/1 King Sol. Won by 2 lengths, 3 lengths second and third.

Skyfuse, a home-bred son of Glenesky and Melton Fuse, gave promise which he was not far short of justifying by running second, beaten less than a length, for the Princess Plate, splitting the joint favourites Datine and Merry Din. The $\$ 2000$ London Cup at Alexandra Park seemed to suit Royal Welsh. Notwithstanding that he was far from leniently treated with 8 st. I 3 lb. he started favourite; as the result proved a false one. But the lapse in the career of victory was brief. Lady Juliet's penalty may have stopped her in the Welter Handicap at the Bibury Club Meeting, but at the Newmarket Second July more brackets were gained by the horses. Bright Folly, 2 to I on, comfortably disposed of Datine and 
half a dozen others, including Lord Derby's Archaicout for the first time-in the Soltykoff Stakes.

NEWMARKET Second July Meeting. Tuesday, July I 5 th. SOLTYKOFF STAKES of $£$ IO each starter, with $£ 400$ added, of which second recd. $£ 50$, for 2 yr. olds; entr. $£ 5$. New T.Y.C., 5 fur. 140 yds. (57 ents. $-£ 4$ I 5 .)

Lord Glanely's b.f. Bright Folly, by Black Jester-Bright, 8 st. II lb. - - - A. Smith I Mr. F. D. Osborne's Datine, 8 st. I I lb. - F. Lane 2 Sir A. Bailey's Envoy, 8 st. 4 lb. - - - F. Fox 3 Mr. J. Buchanan's Grey Monk, 8 st. 4 lb. - J. H. Martin Lord Derby's Archaic, 8 st. 4 lb. (car. 8 st. $6 \mathrm{lb}$.) Sir R. W. B. Jardine's Sea-crest, 8 st. 4 lb. - Wm. Griggs Mr. G. Marsh's Savile Row, 8 st. 4 lb. - - J. Evans Lord Durham's Melosah, 8 st. - - - G. Colling 2/1 on Bright Folly, 5/I agst. Datine, 7/I Envoy. Won by I $\frac{1}{2}$ lengths, 4 lengths second and third.

Starshot cantered away with the Beaufort Stakes, verdict six lengths. Sky-fuse, however, a 3 to I chance, disappointed in the Saxham Plate, and the penalised Starshot was not equal to another effort in the Swaffham Welter, for which he started a 5 to 2 favourite; nor could Lancovil win the Bury Handicap, though no great hope was felt that he would do so.

NEWMARKET Second July Meeting. Tuesday, July 15 th. BEAUFORT STAKES (Welter Handicap) of fio each starter, with $£ 300$ added, of which second recd. $£ 30$; entr. $£ 5$; Beaufort Course, 7 fur. (I9 ents. $-f_{2295}$.)

Lord Glanely's ch.c. Starshot, by Sunstar-

Kitty Muldoon, 3 yrs., 7 st. $6 \mathrm{lb}$. - - G. Hulme I 
Mr. A. E. Barton's Earna, 4 yrs., 8 st. i I lb. - E. Wheatley 2 Mr. S. R. Bastard's Shon Maclean, 4 yrs., 8 st.

2 lb. - - - - - - - - A. Whalley 3

Sir G. Noble's Strolling Saint, 6 yrs., 8 st.

4 lb. - - - - - - - F. Lane

5/4 agst. Starshot, 7/2 Earna, 4/1 Strolling Saint, 9/2 Shon Maclean. Won by 6 lengths, $1 \frac{1}{2}$ lengths second and third.

To Liverpool only one horse was sent, Sky-rocket for the $£ 1000$ Liverpool Plate. It rather seemed that he was bound on a hopeless errand, for Tangiers was in the race and odds of 3 to I were laid on the subsequent Gold Cup winner, who ran well. Not well enough. Sky-rocket beat him a neck, and considering what Tangiers proved himself to be in the Gold Cup and other races, this was a remarkable achievement for Lord Glanely's chestnut.

LIVERPOOL Summer Meeting. Wednesday, July 23rd.

LIVERPOOL PLATE (Handicap) of $£$ IO00, of which second recd. $£ 100$, and third $£ 50$; entr. $£ 20$, or $£ 5$ if dec. $1 \mathrm{~m}$. 6 fur. (22 ents., viz. 8 at $£ 20$ and 14 at $£ 5-£ 830$.)

Lord Glanely's ch.c. Sky-rocket, by Sunstar - Maid of the Mist, 4 yrs., 9 st.

A. Smith I

Sir W. Nelson's Tangiers, 3 yrs., 8 st. 2 lb. - V. Smyth 2 Mr. G. P. Sanday's Eton Hero, 5 yrs., 7 st.

$3 \mathrm{lb}$.

Mr. F. Langley's Dawn of Peace, 4 yrs., 7 st.

II lb. (car. 7 st. I $2 \mathrm{lb}$.) J. Shatwell 3

3/1 on Tangiers, 7/1 agst. Dawn of Peace and Sky-rocket, 8/1 Eton Hero. Won by a neck, length second and third. 
The luck was not equally good at Hurst, where Quantavis, a Quantock filly, and Somerset Lassie, made little show, and Goodwood was to be a blank, though to the Duke of Richmond's meeting the stable only contributed a couple of runners. Scatwell, with 8 st. ro lb., fancied for the Stewards' Cup and backed at 5 to $\mathrm{I}$, proved unequal to the occasion. Here Irish Elegance was favourite at 100 to 30 , and for once the handsome chestnut, burdened with Io st. 2 lb. was to fail, Sir H. Cunliffe-Owen's King Sol gaining an advantage at the start which he never quite lost. Starshot, like Scatwell second favourite for his race, the Charlton Welter, did no better, finishing unplaced to the first favourite Misty Morning. Alexandra Park as usual wound up the Goodwood week, and brought out a colt of class who had only been seen once quite at the beginning of the season, The Midshipmite, a son of Stedfast and La Favorita, who was to do excellent service. Not mentioned in the betting The Midshipmite won from the favourite, the moderate Gunyah occupying that position.

ALEXANDRA PARK August Meeting. Saturday, August 2nd. ALEXANDRA WELTER HANDICAP of $£ 200$, of which second recd. $£ 20$, and third $£ 5$; entr. $£ 4,2 \mathrm{ft}$. I m. 150 yds. (I9 ents.- $f_{1} 171$.)

Lord Glanely's br.c. The Midshipmite, by

Stedfast-Favorita, 3 yrs., 8 st. 13 lb. - A. Smith I Mr. Z. G. Michalinos' The Gunyah, 6 yrs.,

7 st. 13 lb. - * -

- V. Smyth 
Mr. J. L. Ainsworth's Abiad, 4 yrs., 8 st. 2 lb. A. Whalley 3

Mr. E. J. Caldicott's Pennant, a., 9 st. 5 lb. F. Templeman Mr. R. W. B. Jardine's Neutral, 4 yrs.,

8 st. $12 \mathrm{lb}$.

Mr. M. Clapham's Swinerton, 4 yrs., 8 st.

$8 \mathrm{lb}$.

Sir W. Cooke's Kut, 3 yrs., 8 st. 4 lb.

Wm. Griggs

Lady Torrington's Happy Maid, 3 yrs.,

*7 st. Io lb. - - - - - .

Dr. Dixon's St. Gingoulph, 4 yrs., ${ }^{*} 7$ st. 7 lb. J. Livesey

* $5 \mathrm{lb}$. apprentice allowance deducted.

I $/ 4$ agst. The Gunyah, 4/1 Swinerton, 9/2 Abiad, 5/I Neutral, I00/15 Pennant, 100/8 others (offered). Won by a length, neck second and third.

The second week of the Sussex fortnight was not to pass without a further addition to the roll of success, if a modest one withal. Starshot lost the Brighton Highway Handicap by a neck, the three-year-old endeavouring to give the five-year-old Zulanda i $3 \mathrm{lb}$., but Exford took the Southdown Plate.

BRIGHTON August Meeting.

Thursday, August 7th. SOUTHDOWN PLATE of $£ 200$, of which second recd. $£$ io for 3 yr. olds; entr. $£ 3$. I m. ( 5 ents. $\{187$ ).

Lord Glanely's b.c. Exford, by Marcovil-

Lamford, 8 st. 7 lb. - - - - - A. Smith I

Sir E. Hulton's Sabian, 8 st. 4 lb. - - - S. Donoghue 2

Mr. F. Hardy's Burly, 8 st. 7 lb. - - - V. Smyth 3

Sir A. Bailey's Monoghan, 8 st. I I lb. - - F. Fox -

Mr. F. Gretton's Croix de Guerre, 8 st. 2 lb. - A. Whalley Mr. P. Nelke's Cylenius, 8 st. 7 lb. - - M. Wing -

5/4 on Exford, 7/2 agst. Burly, 5/I Sabian. Won by 4 lengths, $\frac{3}{4}$ length second and third. 
A bout this time the horses were not busy, though Scatwell at Nottingham on the i2th of August won the Stewards' Handicap, and on the same afternoon Somerset Lassie secured the Cinque Ports Welter Handicap at the Folkestone Summer Meeting.

NOTTINGHAM Summer Meeting. Tuesday, August 12 th. STEWARDS' HANDICAP of $£ 600$, of which second recd. $£ 50$; entr. $£ \mathrm{I} 3$, or $£ 3$ if dec. 6 fur. straight. (24 ents., viz. 9 at $£ I 3$ and $I 5$ at $£ 3-£ 537$.)

Lord Glanely's ch.c. Scatwell, by Marcovil -Cheshire Cat, 4 yrs., 9 st. 5 lb. - - A. Smith I Mr. T. Davidson's Greenroom, 5 yrs., 7 st. 7 lb. - - - - - - F. Fox 2 Mr. H. W. Rudd's Arwin, 4 yrs., 7 st. - - G. Colling 3 Mr. Sol Joel's Kashmir, 4 yrs., 7 st. 8 lb. - F. Slade Mr. G. W. Smith's Miss Richard, 4 yrs., 6 st. $7 \mathrm{lb}$. - T. Weston Mr. E. Moore's Alderton, 3 yrs., 6 st. 5 lb. (car. 6 st. 7 lb.) A. Flanagan 5/4 agst. Scatwell, 7/2 Kashmir, 5/1 Alderton, 8/1 Greenroom and Miss Richard, I0/I Arwin. Won by a length, $\frac{3}{4}$ length second and third.

FOLKESTONE Summer Meeting. Tuesday, August 12th. CINQUE PORTS WELTER HANDICAP of $£ 200$, of which second recd. $£ 20$, and third $£ 10$; entr. $£ 6,3$ ft., 5 fur. (28 ents.- £i64.)

Lord Glanely's ch.f. Somerset Lassie, by Quantock-The Waif, 3 yrs., 8 st. $7 \mathrm{lb}$. - R. Cooper I Mr. J. Sharp's Starsheen, aged, 8 st. I 3 lb. - H. Jelliss 2 Mr. Arthur Knowle's All Feathers, 3 yrs.,

*6 st. 9 lb. - - - - - - K. Piggott 3 
Mr. A. de Rothschild's Vivat Rex, 3 yrs., 8 st. $8 \mathrm{lb}$
G. Hulme -

Mr. R. G. Knight's Neville Holt, aged, 7 st.

Io lb. (car. 7 st. I I lb.) - - - - E. Piper -

Mr. S. Wootton's Momette, 4 yrs., ${ }^{*} 6$ st. 9 lb. A. Smith -

Lord Cholmondeley's Promoter, 5 yrs., ${ }^{*} 6$ st.

9 lb. - - - - - - J. Hine

* 5 lb. apprentice allowance deducted.

Even Somerset Lassie, 3/I agst. Starsheen, 5/I Momette, 7/I Vivat Rex. Won by $1 \frac{1}{2}$ lengths, same second and third.

A week later the same filly carried off the Wyfold Handicap at Wolverhampton.

WOLVERHAMPTON Summer Meeting. Monday, August 18 th. WYFOLD HANDICAP of $£ 300$, of which second recd. $£ 20$; winners extra; entr. $£ 6,3$ ft., 6 fur. straight. (28 ents. $\left.-f_{2} 274.\right)$

Lord Glanely's ch.f. Somerset Lassie, by Quantock-The Waif, 3 yrs., 7 st. I $3 \mathrm{lb}$. (incl. 7 lb. extra) - - - - - R. Cooper I Mr. O. W. Rayner's Verdun, 6 yrs., 9 st. - F. Templeman 2 Mrs. Rudd's Safety Pin, 4 yrs., 7 st. (car.

7 st. 6 lb.) - - - - - F. Fox 3

Mr. J. J. Cowap's Merry Aldford, 3 yrs., 6 st. 9 lb. (car. 6 st. Io lb.) - - - A. Flanagan 5/4 agst. Somerset Lassie, 9/4 Verdun, 5/2 Safety Pin, 20/1 Merry Aldford. Won by $\mathrm{I} \frac{1}{2}$ lengths, head second and third; Merry Aldford jumped across Safety Pin at the start, and caused him to lose two or three lengths; Merry Aldford took no part in the race. An objection to the winner, by the rider of the third, on the ground of bumping and crossing, was overruled, but the deposit money was returned.

With the exception of Bright Folly it will be seen that the two-year-olds were not doing well, and the 103 
first attempt of Rosedoon, a son of Roseland and Kitty Muldoon in the Bushbury Two-Year-Old Plate at Wolverhampton, did not alter the luck. After a second attempt he was sent to Brazil. A number of meetings were then missed, but Bright Folly went to fulfil her engagement in the Champion Breeders' Foal Stakes at Derby, and landed the odds laid on her from Prince Herod, if with nothing to spare.

DERBY Summer Meeting.

Tuesday, September 2 nd. CHAMPION BREEDERS' FOAL STAKES of $£ 800$, of which nominator of winner recd. $£ 100$, and owner and nominator of second $£ 25$ each, for 2 yr. olds ; entr. $£ 12, £ 7$ if dec. by March 25, 1919, or $£_{\mathrm{I}}$ if dec. by Oct. 8, 1918; 5 fur. $(99$ ents., viz. $4 \mathrm{I}$ at $£ 12,15$ at $£ 7$, and 43 at $£ 1-£ 738$.)

Lord Glanely's b.f. Bright Folly, by Black

Jester-Bright, 8 st. 13 lb. - - - A. Smith I

Mr. J. White's Prince Herod, 9 st. 5 lb. - F. Templeman 2

Mr. Z. G. Michalinos' Pelops, 8 st. I3 lb. - V. Smyth 3

Mr. F. Hardy's Charlie's Smile, 8 st. I3 lb. F. Lane -

Sir J. Robinson's Lucentio, 8 st. 5 lb. - F. Slade -

5/4 on Bright Folly, 9/4 agst. Prince Herod, 7/1 Pelops, 10/1 Charlie's Smile, 20/1 Lucentio. Won by a head, short head second and third.

Sea Song was sent to Manchester with the result which follows :

MANCHESTER September Meeting. Saturday, September 6 th. EGERTON THREE-YEARS-OLD HANDICAP of $£ 500$, of which second recd. $£ 50$; entr. $£ 9$, or $£ 3$ if dec. 6 fur. straight. (27 ents., viz. 14 at $£ 9$ and 13 at $£ 3-£ 44 \mathrm{I}$.)

Lord Glanely's ch.g. Sea Song, by Phaleron

-Miss L. Thrush, 8 st. 7 lb. - - - A. Smith 1 
Lord Ellesmere's Trespasser, 8 st. $12 \mathrm{lb}$. - H. Jelliss 2 Mr. C. E. Howard's Sunny Rhyme, 8 st. 3 lb. N. Spear 3 Mr. W. B. Richardson's Linggi's Boy, 8 st.

8 lb. - - - - -. - - J. H. Martin Mrs. Rudd's Day Dream, 8 st. 4 lb. - - B. Carslake Mr. W. M. Cazalet's The Sphinx, 8 st. 3 lb. (car. 8 st. 4 lb.) Lord Jersey's Calypso, 7 st. I 3 lb. - - G. Hulme Mr. E. Moore's Alderton, 7 st. 13 lb. - - F. Fox -

3/I agst. Alderton, 5/I Linggi's Boy, Sunny Rhyme, and Calypso, 6/1 Day Dream, Sea Song, and The Sphinx, I0/I Trespasser. Won by 4 lengths, neck second and third.

"Nothing to spare" must also be written about Lord Derby's Rosacre in the Belper Maiden Plate, as it was only by a head, stated moreover to be a short one, that he beat Powerful later in the afternoon. An occurrence next day which created some surprise was the defeat of Dominion in the Breeders' St. Leger. He was backed at I 3 to 8 on, and though the winner, Chuette, was no doubt a good filly at her best, it is unaccountable that Dominion should have been beaten six lengths for second place by so moderate an animal as Mademoiselle Foch. Obviously he could not have been himself. Nurseries had now begun, and Cutty Sark led the way in the Palatine at Manchester. Whatever chance he might have had was lost at the post, though it may be admitted that he was not likely to have beaten Fair Simone, a really good two-year-old. As is so often the case she lost her form after her first season. 
Dominion entirely rehabilitated his character at Doncaster. The Leger was generally regarded as a good thing for Buchan, with odds of I I to 8 on him; of the others the market suggested that Dominion was the only one with a reasonable chance; about him 7 to I was to be had, then coming roo to 8 Keysoe and Pomme de Terre. Keysoe showed form which she has never repeated, winning by half a dozen lengths. Dominion followed her home, reversing previous performances with Buchan, whom he here beat by two lengths. Lord Glanely started a second string, Trowbridge, a useful colt in his class who probably ran as well as anyone supposed he would.

DONCASTER September Meeting.

Wednesday, Sept. Ioth, I9I9.

ST. LEGER STAKES of $£ 6500$ (including $£ 500$ for nominator of winner) with $£ 400$ for second and $£ 200$ for third, by subscription of $£ 50$ each, h.ft., or $£ 5$ if dec. ; for 3 yr. olds, entire colts and fillies; colts 9 st., fillies 8 st. I I lb. St. Leger Course, about I m. 6 fur. I 32 yds. (2 I I ents., viz. Io at $£ 50$, I 22 at $£ 25$, and 79 at $£ 5-£ 6450$.)

Lord Derby's b.f. Keysoe, by Swynford-

Keystone II., 8 st. I I lb.

- B. Carslake I

Lord Glanely's b.c. Dominion, 9 st. - - A. Smith 2

Major W. Astor's b.c. Buchan, 9 st. - - J. Childs 3

Lord Zetland's b.c. Pomme-de-terre, 9 st. - H. Robbins 4 His Majesty's b.c. Viceroy, 9 st. - - H. Jones Mr. Sol Joel's b.c. Sardis, 9 st. - - - F. Templeman Capt. Lionel Montagu's b.c. White Heat, 9 st.

Lord Glanely's br.c. Trowbridge, 9 st. H. Jelliss - G. Stephenson - 
Major J. B. Paget's ch.f. Mademoiselle Foch, 8 st. II lb.

Mr. A. Lowry's ch.c. Cheap Popularity, 9 st.

G. Colling

J. Ledson

II $/ 8$ on Buchan, $7 / 1$ agst. Dominion, I00/8 Keysoc and Pomme-de-terre, 100/7 Cheap Popularity, and 20/I Viceroy.

Won by 6 lengths, 2 lengths second and third.

Lady Juliet was thought to have some chance for the Portland Plate, in which again Irish Elegance had things all his own way, making light of his ro st. 2 lb., but in the Alexandra Handicap The Midshipmite, as the phrase goes, "made an example" of Monteith, Royal Bucks and others by cantering home with eight lengths to spare. The colt had found his form.

DONCASTER September Meeting. Thursday, September I 1 th. ALEXANDRA HANDICAP of $£ 500$, of which second recd. f.50 and third $£ 25$; entr. $£ 15,5$ ft. $\quad 1 \frac{1}{2} \mathrm{~m} . \quad$ (27 ents.$£ 4$ IO.)

Lord Glanely's br.c. The Midshipmite, by

Stedfast-Favorita, 3 yrs., 7 st. 8 lb. - A. Whalley I Mr. R. B. Thorburn's Monteith, 3 yrs., 7 st.

$7 \mathrm{lb}$.

- F. Lane

Lady Queensberry's Royal Bucks, 6 yrs.,

8 st. I I lb. - - - $\quad$ - $\quad$ -

8 st. $7 \mathrm{lb}$. . - . .

Lord Lascelles' King Eber, 3 yrs., 7 st. 3 lb. K. Robertson Mr. E. G. de Mestre's Dorelus, 3 yrs., 7 st.

$1 \mathrm{lb}$.

F. Templeman 3

7/4 agst. The Midshipmite, 3/I Monteith, 4/1 Dorelus, 11/2 Royal Bucks, 8/1 Morning Star, 100/8 King Eber. Won by 8 lengths, $1 \frac{1}{2}$ lengths second and third. 
Willblend, the son of William Rufus and Pitch Blend, was sent on an expedition to Pontefract for the Newby Nursery, which it was accurately imagined would be within his compass.

PONTEFRACT Autumn Meeting. Wednesday, Sept. 24th. NEWBY NURSERY HANDICAP of $£ 200$, of which second recd. $£ 20$ and third $£$ ro; entr. $£\} .5$ fur. $(32$ ents.E167.)

Lord Glanely's b.g. Willblend, by William

Rufus-Pitch Blend, 8 st. I lb. - - - A. Whalley I

Mr. H. Summarsell's Redwings, 8 st. 8 lb. - W. Saxby 2 Mr. Lester's Wendy, *6 st. I2 lb. (car. 7 st.

$2 \mathrm{lb}$.$) - - - - - W. Balding 3$

Mr. H. A. Crallan's Holiday II., 9 st. - - G. Topping -

Mr. J. W. Harvie's Cumberland, 8 st. 8 lb. - M. Wing -

Mr. E. C. Hill's Exton, 8 st. 7 lb. - - - J. Thwaites -

Mr. J. Watts' Canterbury Tales, 8 st. I lb.

(car. 8 st. 2 lb.) - - - - - F. Leach

Mr. G. C. Sharpe's Varia, 7 st. I 2 lb. - - G. Colling -

Mr. J. McNewland's Park Avenue, 7 st. 3 lb. C. Ringstead -

Mr. J. A. Dunkerley's Bon Peach, *6 st. Io lb. T. Weston -

* $5 \mathrm{lb}$. apprentice allowance deducted.

5/4 agst. Willblend, 4/I Bon Peach, 6/1 Redwings, 7/I Varia, 8/I Wendy, 10/I Cumberland and Canterbury Tales. Won by $1 \frac{1}{2}$ lengths, 2 lengths second and third.

Trowbridge accompanied him and also scored.

PONTEFRACT Autumn Meeting. Thursday, Sept. 25th.

HAREWOOD PLATE of $£ 200$, of which second recd. $£ 20$ and third $£_{10}$, for 3 yr. olds and upwards, maidens at closing ; entr. $£ 3$. I $\frac{1}{2} \mathrm{~m}$. (3I ents. $-E_{6} 167$.)

Lord Glanely's br.c. Trowbridge, by Bridge

of Earn-La Danseuse, 3 yrs., 8 st. 5 lb. - G. Stephenson I 108 
Lord Londonderry's Dorset, 3 yrs., 8 st.

5 lb. - - - - - - - J. Thwaites 2

Mr. D. McKechnie's Pretty Nannie, 3 yrs.,

8 st. 2 lb. - - - - - - J. Elliott 3

Mr. G. Renwick's Zizel, 6 yrs., 8 st. II lb. - A. Salmon -

Capt. E. L. Wheelwright's Blazing Corn,

5 yrs., 8 st. I I lb. - - - - - P. Jones -

Miss I. Frost's Miss Ethel, 3 yrs., 8 st. 2 lb. F. Hopper -

13/8 on Trowbridge, $7 / 4$ agst. Dorset, 100/6 Zizel. Won by

3 lengths, bad third.

There were few runners at the Newmarket First October Meeting, but it was by an easy six lengths that The Midshipmite beat His Majesty's Viceroy for the Great Foal Stakes.

NEWMARKET First October Meeting. Tuesday, Sept. 3oth.

GREAT FOAL STAKES of $£ 10$ each starter, with $£$ rooo added, of which nominator of winner recd. $£ 100$, owner of second $£ I 50$, nominator of second $£ 50$, and owner of third $£ 50$, for 3 yr. olds; entr. $£ 10$, or $£ 5$ if dec.; A.F., I $1 \frac{1}{4}$ m. (74 ents., ft. dec. for $19-£ 780$ ).

Lord Glanely's br.c. The Midshipmite, by

Stedfast-Favorita, 8 st. $12 \mathrm{lb}$. - - A. Smith I

His Majesty's Viceroy, $8 \mathrm{st} .12 \mathrm{lb}$. - - H. Jones 2

Lord Durham's Carapace, 8 st. 7 lb. - - B. Carslake 3

Mr. J. Sharp's Fast and Furious, 8 st. 7 lb. - F. Fox -

Mr. P. Nelke's Win the War, 8 st. - - - M. Wing -

II/10 on The Midshipmite, 2/I agst. Viceroy, 100/1 5 Carapace, 8/1 Win the War, 20/1 Fast and Furious. Won by 6 lengths, same second and third.

The afternoon yielding more profit, as Scatwell beat Sir Robert Jardine's Neutral by twelve lengths for a 
Triennial. Here the distance was two miles, and Scatwell's best course was a good deal less than half as far while Neutral was a stayer: the last race he had won was over a mile and five furlongs. This Triennial was indeed an interesting proof of the value of class. Scatwell had so great an advantage in this particular that nonstayer as he was he beat the stayer in the simplest of canters.

NEWMARKET First October Meeting. Tuesday, Sept. 30th. 3RD YEAR OF 7ОTн TRIENNIAL PRODUCE STAKES of $£ 10$ each starter, with $£ 300$ added for owner and $£ 100$ for nominator of winner, for $4 \mathrm{yr}$. olds; second recd. $10 \%$ of whole stake; entr. $£ 3$; last $2 \mathrm{~m}$. of Cesarewitch Course (54 ents. $-£ 365$ ).

Lord Glanely's ch.c. Scatwell, by Marcovil-

Cheshire Cat, 9 st. - - - - - A. Smith I

Sir R. W. B. Jardine's Neutral, 9 st. - - Wm. Griggs 2

9/4 on Scatwell. Won by 12 lengths.

Between the Newmarket Meetings the horses were far from idle, Sea Song went to Leicester, where he won the Kegworth Handicap, as the betting had suggested he would.

LEICESTER October Meeting. Thursday, Oct. 9th. KEGWORTH HANDICAP of $£ 300$, of which second recd. $£ 20$ and third $£ 10$; entr. $£ 6,3 \mathrm{ft}$; 7 fur. straight (44 ents.(264).

Lord Glanely's ch.g. Sea Song, by Phaleron-

Miss L. Thrush, 3 yrs., 8 st. 5 lb. - - A. Whalley I Sir E. Hulton's Sabian, 3 yrs., 8 st. - - S. Donoghue 2 
Mr. Lester's Main Royal, 4 yrs., 8 st. 7 lb. - F. Lane 3 Mr. Sol Joel's Cutaway, 4 yrs., 8 st. 4 lb. - H. Jelliss Lord Ellesmere's Trespasser, 3 yrs., 8 st. I lb. F. Slade Mr. J. White's Sea Imp, 6 yrs., 7 st. 6 lb. - G. Colling Mr. H. G. Bradford's Tunworth, 4 yrs., 7 st. 5 lb. (car. 7 st. 6 lb.).- - - - F. Fox Mr. A. E. V. Barker's Redouble, 5 yrs., 6 st. 9 lb. (car. 6 st. Io lb.) - - . Mr. Russell Swanwick's Countess Burghley, 3 yrs., 6 st. 8 lb. (car. 6 st. Io lb.) - - A. Flanaghan Mr. A. J. Long's Rosy Picton, 3 yrs., 6 st. 7 lb.

(car. 6 st. 9 lb.) - - - - - K. Robertson -

2/I agst. Sea Song, 9/2 Tunworth, 6/1 Main Royal, 7/1 Cutaway, Sabian and Sea Imp, 8/1 Countess Burghley. Won by a length, $1 \frac{1}{2}$ lengths second and third; Tunworth was unruly at the start and lost several lengths.

And richer prizes were waiting at Kempton, where The Midshipmite won a fourth consecutive race, the Coventry Plate.

KEMPTON PARK October Meeting. Friday, Oct. Ioth.

COVENTRY PLATE (Welter Handicap) of $£ 500$, of which second recd. $£ 30$ and third $£ 20$; winners extra ; entr. $£ 12$, or $£ 4$ if dec. ; I $\frac{1}{2} \mathrm{~m}$. on Round Course (33 ents., viz. I9 at $£ 12$ and $£ 14$ at $4-£ 438$ ).

Lord Glanely's br.c. The Midshipmite, by Stedfast-Favorita, 3 yrs., 9 st. I lb. (inc.

7 lb. extra) - - - - - A. Smith I

Mr. W. M. Cazalet's Elsinore, 3 yrs., 8 st. 6 lb. J. Childs 2 Mr. R. C. Dawson's Avezzano, 6 yrs., 7 st. 7 lb.

(car. 7 st. 8 lb.) - - - - - G. Hulme 3

Mr. R. Wootton's Zulanda, 5 yrs., 8 st. 8 lb. - V. Smyth Mr. R. R. Jeffrey's Limpsfield, 4 yrs., 8 st. 4 lb. B. Carslake - 
Sir G. Murray's Coriolanus, 3 yrs., 8 st. - F. Fox Mr.W.H. Dixon's Black Lamb, 5 yrs., 7 st. 7 lb. W. Balding $7 / 4$ agst. The Midshipmite, 3/1 Limpsfield, 6/1 Coriolanus, 7/1 Elsinore, 8/1 Zulanda, I0/1 Avezzano, 20/1 Black Lamb. Won by a short head, $1 \frac{1}{2}$ lengths second and third.

For once Grand Fleet demonstrated his capacity by carrying off the Duke of York's Stakes, which a majority of backers regarded as something like a match between the two fillies My Dear and Chuette.

KEMPTON PARK October Meeting. Saturday, Oct. IIth. DUKE OF YORK STAKES (Handicap) of $£ 2000$, of which second recd. $£ 200$ and third $£ 100$, by subscription of $£ 35$, $30 \mathrm{ft}$., or $f_{5} 5$ if dec.; Jubilee Course, $1 \frac{1}{4} \mathrm{~m}$. (44 ents., viz. 10

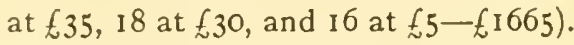

Lord Glanely's b.h. Grand Fleet, by Bachelor's

Double-Dark Dinah, 5 yrs., 8 st. I lb. Duke of Portland's Sir Berkeley, 4 yrs., 6 st. ro lb. - - - - . Mr. F. Darling's Vice Versa, 3 yrs., 6 st. 2 lb. (car. 6 st. 4 lb.) - - - - . Capt. G. C. H. Davy's Chuette, 3 yrs., 7 st. 9lb. Mr. A. R. Cox's My Dear, 4 yrs., 9 st. - Mr. G. Barclay's Planet, 5 yrs., 7 st. 13 lb. -
Mr. Russell Swanwick's Palcstrina, 3 yrs., 6 st. 7 lb. (car. 6 st. $10 \mathrm{lb}$.) - - . Mr. R. R. Jeffrey's Limpsfield, 4 yrs., 6 st. 6 lb. Lord Derby's Glaciale, 3 yrs., 6 st. 5 lb. (car. 6 st. 6 lb.) - - - - - - 6 st. 4 lb. - - - - - - J. McCracken 9/4 agst. My Dear, 3/1 Chuette, 100/15 Grand Fleet, 7/1 Sir Berkeley and Vice Versa, I00/8 Planet, 100/7 Glaciale. Won by $\frac{3}{4}$ length, 2 lengths second and third. 


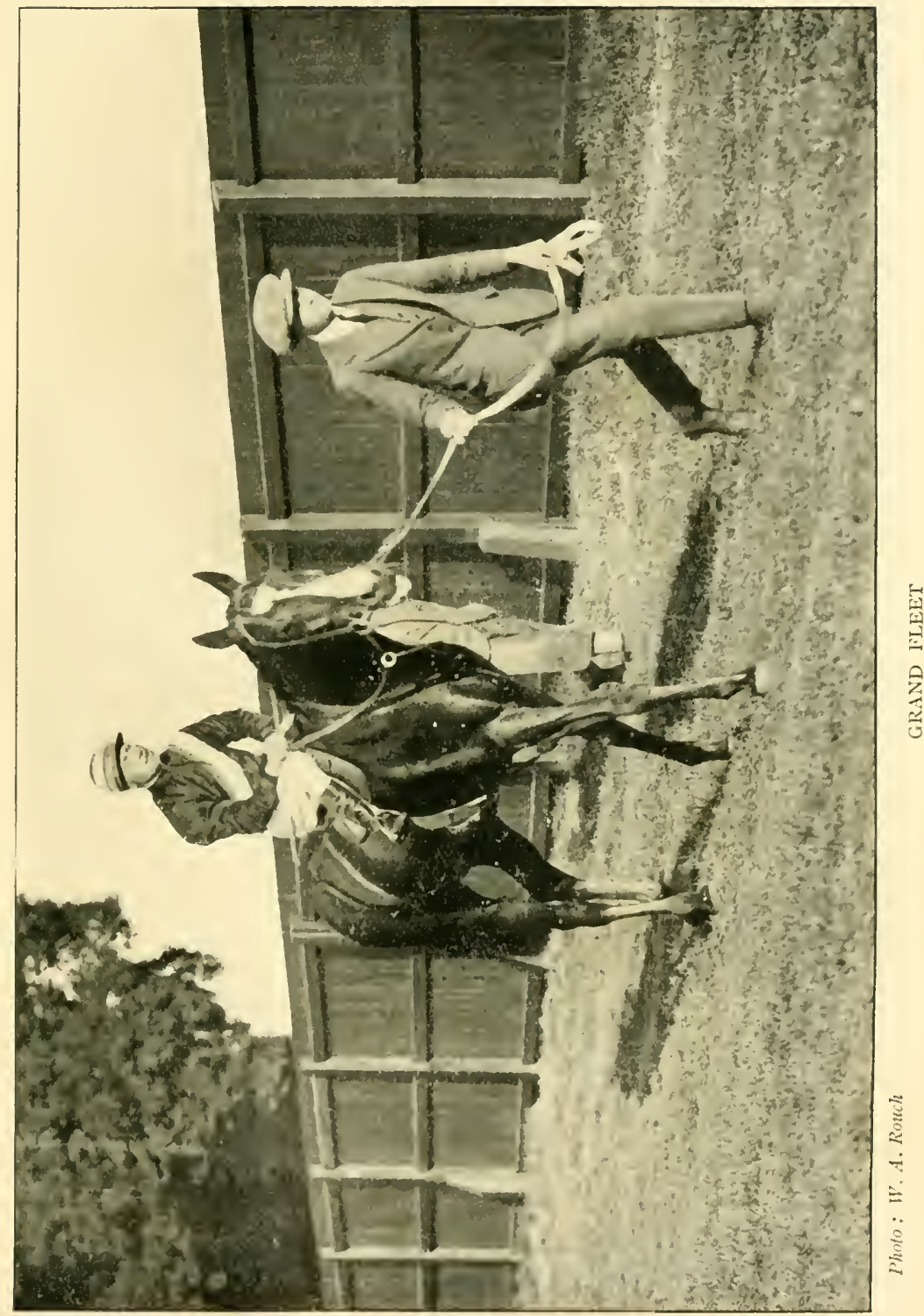






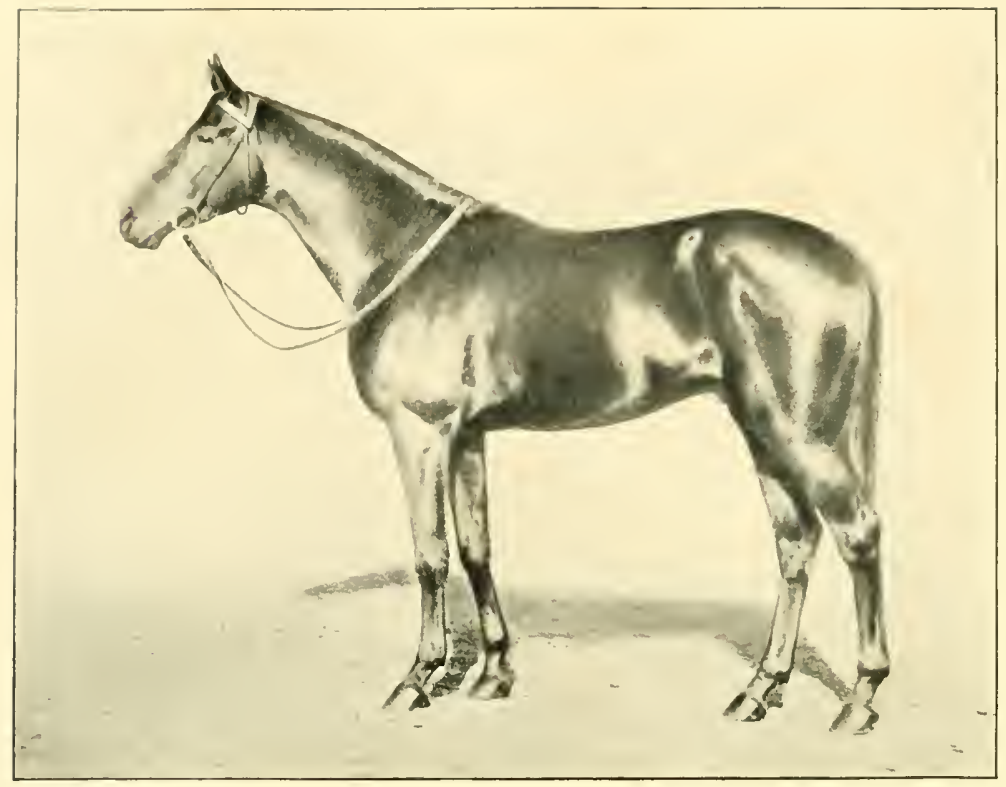

Photo: II. A. Rouch

THE MIDSHIPMITE

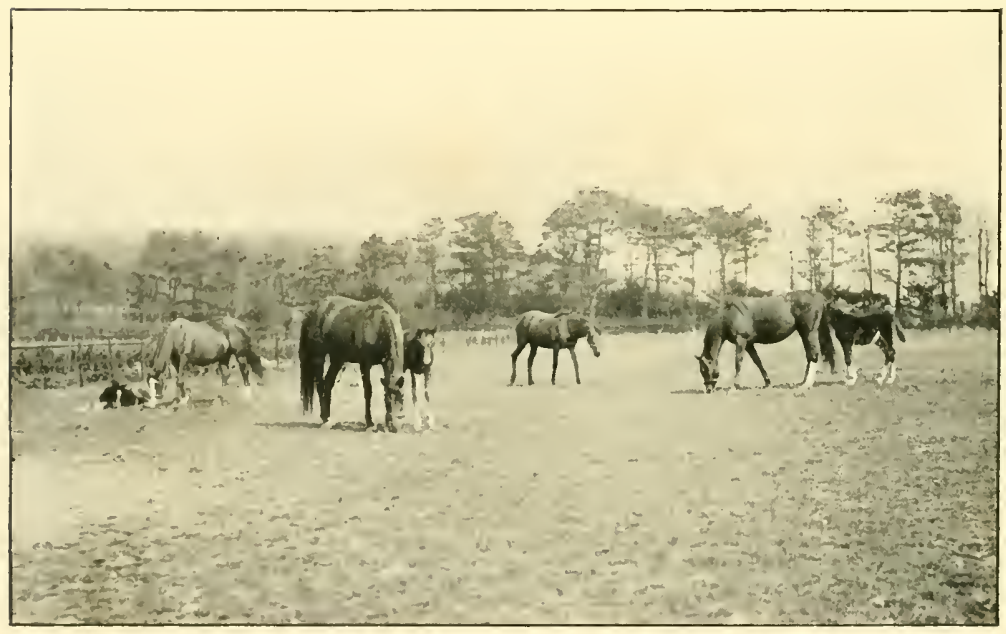

Photo: II. A. Rouch 
Passing on to the Newmarket Second October, the undefeated Bright Folly won the Cheveley Park Stakes in a canter.

NEWMARKET Second October Meeting.

Wednesday, Oct. I 5 th.

CHEVELEY PARK STAKES of $£ 20$ each, h.ft., with $£ 400$ added, for 2 yr. old fillies; second recd. $f_{1} 100$ out of stakes, and third saved stake; entr. $f 5$, the surplus amounting to £125; Bretby Stakes Course, 6 fur. (105 ents. $-£ 1395$ ).

Lord Glanely's b.f. Bright Folly, by Black

Jester-Bright, 9 st. 6 lb. - - • - A. Smith 1

Mrs. H. Cayzer's Plunkette, 9 st. $10 \mathrm{lb} .-$ - A. Whalley 2

Baron E. de Rothschild's Cicérole, 8 st. I lb. - G. Hulme 3

His Majesty's Sunny Princess, 8 st. Io lb. - H. Jones -

Sir A. Bailey's Saffron, 8 st. $10 \mathrm{lb}$. - - F. Fox -

Mr. W. M. Cazalet's Lady Ava, 8 st. 10 lb. - J. Childs -

Mr. William Clark's Cooreena, 8 st. Io lb. - B. Carslake -

Lord Rosebery's Nespola, 8 st. Io lb. - - S. Donoghue -

Sir J. Thursby's Bound Over, 8 st. Io lb. - F. Templeman-

5/4 agst. Bright Folly, 4/i Nespola, 9/2 Cooreena, 10/1 Sunny Princess. Won by 4 lengths, head second and third.

And The Midshipmite wound up by dead-heating for the last race on the last day, the Southfield Plate, with the Manton-trained Kentish Cob, Mr. Cazalet's colt in receipt of $9 \mathrm{lb}$.

NEWMARKET Second October Meeting. Friday, Oct. 17 th. SOUTHFIELD PLATE of $£ 300$, of which second recd. $£ 30$, for $3 \mathrm{yr}$. olds and upwards; entr. $f .5$; last $1 \frac{1}{2} \mathrm{~m}$. of Cesarewitch Course (12 ents. $-£ 265$ ).

Lord Glanely's br.c. The Midshipmite, by

Stedfast-Favorita, 3 yrs., 8 st. I 3 lb. - A. Smith 0 


\section{A GREAT YEAR}

Mr. W. M. Cazalet's b.c. Kentish Cob, by Sunstar-Maid of Kent, 3 yrs., 8 st. 3 lb. (car. 8 st. 4 lb.) - . - . . Mr. J. A. de Rothschild's Filigrane, 4 yrs., 7 st. I I lb.

Mr. G. Blackwell's The Grove, 4 yrs., 7 st. II lb.

E. Crickmere 3

4/I on The Midshipmite, 5/I agst. Kentish Cob. A dead heat, bad third. Stakes divided.

Before running for the Mile Maiden Plate at Newbury Powerful had twice been second. He was the only horse of Lord Glanely's to run at the meeting.

NEWBURY October Meeting.

Tuesday, Oct. 2 Ist.

MILE MAIDEN (at closing) PLATE of $£ 300$, of which second recd. $£ 30$ and third $f_{1} 15$, for 3 yr. olds and upwards; entr. $£ 6,3 \mathrm{ft}$., I m. straight (3 I ents. $-£ 249$ ).

Lord Glanely's b.c. Powerful, by Polymelus

-Flori, 3 yrs., 8 st. 7 lb. -

Lord Rosebery's Vertigo, 3 yrs., 8 st. 7 lb.-

Mr. F. R. Fry's Treasury Bill, 4 yrs.,

8 st. I I lbs.

Mr. E. G. de Mestre's Dorelus, 3 yrs.,

8 st. 7 lb.

Mr. M. D. Blair's Krooner, 3 yrs., 8 st. 4 lb. J. Shatwell

Mr. P. F. Hartigan's Royal Hussar, 3 yrs.,

8 st. $4 \mathrm{lb}$.

Duke of Portland's Blood Royal, 3 yrs.,

8 st. $4 \mathrm{lb}$.

3/I agst. Dorelus, I00/30 Powerful, 4/I Vertigo, 5/I Blood Royal, 6/I Royal Hussar. Won by 4 lengths, neck second and third.
A. Smith I

F. Templeman 2

W. Saxby 
Only Quanta, the daughter of Quantock and Mentha, went to Sandown, where she did no good. This was one of the few selling races in which any of the horses took part during the season. Skyfuse came extremely near to winning the Downe Nursery at Stockton, beaten a head and a neck by Adornain receipt of $7 \mathrm{lb}$.- - and Jaunting Car, March Along favourite. At Birmingham Lord Glanely ran two horses and both were second, Grand Fleet endeavouring to give the winner of the Birmingham Handicap $38 \mathrm{lb}$., and Willblend beaten a head for the Coventry Nursery. The Houghton was not materially to swell the total. Lady Juliet failed in the Fordham Welter, Willblend just got a place in the New Nursery ; Scatwell, starting at 100 to 14 , and Dominion 100 to 7 , were beaten in the Cambridgeshire, behind Brigand, Diadem and My Dear; but Trowbridge made a minor contribution, for he followed the example of The Midshipmite and oddly enough dead-heated with Kentish Cob for the Scarbrough Stakes, Lord Glanely's colt this time in receipt of weight $-8 \mathrm{lb}$.

NEWMARKET Houghton Meeting. Wednesday, Oct. 29th. SCARBROUGH STAKES of $£ 5$ each starter, with $£ 200$ added, of which second recd. $£ 30$, for 3 yr. olds; entr. $£ 3$; last I $\frac{1}{2} \mathrm{~m}$. of Cesarewitch Course (14 ents. $-£ 187$ ).

Mr. W. M. Cazalet's b.c. Kentish Cob, by

Sunstar-Maid of Kent, 9 st. 13 lb. - - J. Childs O Lord Glanely's br.c. Trowbridge, by Bridge of

Earn-La Danseuse, 9 st. 5 lb.

A. Smith o 
Lady Farrar's King Alfred, 7 st. I3 lb. - - F. Fox 3 Mr. P. Nelke's Polichinelle, 8 st. 6 lb. - - S. Donoghue 4 Mr. W. H. Dixon's Royal Diamond, 8 st. 2 lb. M. Wing -

7/4 agst. Kentish Cob, 4/I Trowbridge and Polichinelle, 9/2 Royal Diamond, 8/1 King Alfred. A dead heat, third beaten 4 lengths. Stakes divided.

Exford could only get third for an Apprentice Plate, and Lancovil, not so near for the Queensberry Handicap, but it was by a short head that Scatwell failed to give I 8 lb. to Leandros in the Durham Handicap. In the London Autumn Cup at Alexandra Park Lord Glanely did not compete. He took the event which followed, the Highgate Mid-weight Handicap with Somerset Lassie.

ALEXANDRA PARK November Meeting. Saturday, Nov. Ist.

HIGHGATE MID-WEIGHT HANDICAP of $£ 200$, of which second recd. $£ 20$ and third $£_{10}$; entr. $£ 4,2$ ft., 5 fur. (32 ents.- $\{\mathrm{I} 66)$.

Lord Glanely's ch.f. Somerset Lassie, by

Quantock-The Waif, 3 yrs., 8 st. 13 lb. - G. Hulme I

Col. E. F. Morrison-Bell's Lady Symline, 4 yrs.,

8 st. 8 lbs.

S. Donoghue 2

Mr. W. H. Dixon's D.N.P., 4 yrs., 8 st. 4 lb. M. Wing 3 Mme. M. Varipati's Pourboire, 3 yrs., 8 st. 3 lb. J. Shatwell Sir W. Cooke's Divide, 3 yrs., 8 st. 2 lb. - F. Slade Mr. H. Cunliffe-Owen's Love Note, 3 yrs.,

* 7 st. 13 lb.

J. Leach

Mr. Horatio Bottomley's Irish Fair, 3 yrs.,

7 st. 10 lb. - - - - - - E. Crickmere -

Mr. R. Carvalho's Deccan, 5 yrs., 7 st. 7 lb.

(car. 7 st. $8 \mathrm{lb}$.)

- V.Smyth 


\section{THE GREAT YEAR}

Lord Zetland's All Clear, 3 yrs., * 6 st. 9 lb. - A. Garnett Mr. T. P. King's Anyway, 3 yrs., * 6 st. 9 lb. T. Weston ${ }^{*} 5 \mathrm{lb}$. apprentice allowance deducted.

2/1 agst. Anyway, 4/I Pourboire, 7/1 Somerset Lassie, 8/1 Lady Symline, D.N.P., Love Note, and All Clear, Io/r Divide. Won by $\frac{3}{4}$ length, $\frac{1}{2}$ length second and third.

$A$ win and a place were the best that could be done at the Liverpool Autumn Meeting, where the useful Sea Song gained a fourth victory.

LIVERPOOL Autumn Meeting.

Friday, Nov. 7 th.

CROXTETH PLATE (Handicap) of $£ 300$, of which second recd. $£ 20$; entr. $£ 4$; Anchor Bridge Course, 6 fur. $(29$ ents. $-\{276)$.

Lord Glanely's ch.g. Sea Song, by Phaleron-

Miss L. Thrush, 3 yrs., 8 st. 9 lb. - .

Sir W. Cooke's Divide, 3 yrs., 7 st. 6 lb. (car.

7 st. $7 \mathrm{lb}$.)

A. Smith I

Lord Derby's Santa Cruz, 3 yrs., 8 st. 5 lb. - G. Colling

Mr. C. Burn's The Plough, 4 yrs., 8 st. 7 lb. - S. Donoghue -

Mr. H. S. Persse's Golden Quiver, 4 yrs.,

8 st. 7 lb. - - . - - . -

Mr. A. Bendir's Orsan, 3 yrs., 8 st. 3 lb. - F. Lane -

Mr. W. H. Dixon's Twincat, 5 yrs., 8 st. I lb. M. Wing -

Mr. H. Cunliffe-Owen's Love Note, 3 yrs.,

7 st. 9 lb. - - . - . - J. Leach

Mr. J. McLean's Buzz Off, 4 yrs., 7 st. 7 lb. - D. McGuigan -

Mr. H. Dyke Dennis' White Frost, 4 yrs.,

7 st. 5 lb. - - - - - - - T. Weston -

Mr. Reid Walker's Kerry Lass, 3 yrs.,

7 st. 5 lb. - - - - - - - J. Shatwell -

Mr. Barclay Walker's Ensay, 3 yrs., 7 st. 4 lb. - W. Balding -

9/4 agst. Orsan, 9/2 Sea Song, 7/1 Golden Quiver and Santa Cruz, $8 / \mathrm{I}$ Divide, Io/I White Frost. Won by $1 \frac{1}{2}$ lengths, $\frac{3}{4}$ length second and third. 
Mighty Power finished third to Fair Simone aforementioned and Tarvie for the fiooo Knowsley Nursery. Dominion found $8 \mathrm{st} .2 \mathrm{lb}$. beyond his capacity in the Cup, and Willblend, starting favourite for the Durham Nursery, failed to get into the first three. Lancovil at his seventh attempt won the Quorndon Maiden Plate at Leicester.

LEICESTER November Meeting. Monday, November Ioth.

QUORNDON MAIDEN (at closing) HANDICAP of £106; second saved entrance out of plate; entr. $£ 3.6$ fur. straight. (21 ents. $-£ 100$.

Lord Glanely's ch.c. Lancovil, by Marcovil

-Lantana, 3 yrs., 7 st. 5 lb. (car. 7 st.

7 lb.) - - - - A. Whalley I

Dr. Dixon's St. Gingoulph, 4 yrs., 7 st. 5 lb. - E. Crickmere 2 Mr. H. W. Rudd's Sunny Vista, 5 yrs., 6 st.

12 lb. (car. 7 st. 2 lb.) - - - - G. Colling 3

Mr. Russell Swanwick's Countess Burghley,

3 yrs., 7 st. 9 lb. - - - - - -

Mr. Horner Geipel's Houplines, 3 yrs., ${ }^{*} 6$ st.

4 lb. (car. 6 st. $10 \mathrm{lb}$.) - - - - A. Garnett -

Mrs. Prankerd's Athenian, 5 yrs., *6 st. $2 \mathrm{lb}$.

(car. 6 st. 4 lb.) - - - - .

Mr. V. Lambourne's Simon the Cellarer, 5 yrs.,

*6 st. $2 \mathrm{lb}$.

J. Bond

A. Smith

* $5 \mathrm{lb}$. apprentice allowance deducted.

I I/10 agst. Lancovil, $11 / 4$ St. Gingoulph, 6/1 Countess Burghley, 8/1 Sunny Vista. Won by 3 lengths, 6 lengths second and third.

At Derby Scatwell came within a length and a half of giving the City and Suburban winner Corn Sack 118 
exactly I st. in the Markeaton Plate-Scatwell had 8 st. $8 \mathrm{lb}$., and Corn Sack put in with 7 st. $5 \mathrm{lb}$, carried $3 \mathrm{lb}$. extra in order that Weston might ride. In a field of sixteen Glenhattie lost the Elvaston Castle Plate by a head and a neck. Alasnam, whom Sir Abe Bailey had confidently expected for the Cesarewitch and then for the Cambridgeshire, carried off the Derby Cup with the easy burden of 6 st. Io lb., The Midshipmite well up fourth with 8 st. $4 \mathrm{lb}$.

All the horses that were fit were sent to Manchester for the concluding meeting of the season, numbering ten in all. Trowbridge ran behind that perplexing creature Ugly Duckling for the Brackley Welter. In the Rothschild Maiden Plate there was trouble. Powerful won by a length and a half from Enniskeen, whose trainer objected on the ground that Powerful was not a maiden at the time of entry. As recorded he had won a race at Newbury. The Stewards of course upheld the objection, and furthermore fined the trainer Barling fio. This was on the Thursday. Next day Lahloo at his second attempt won the Pendleton Maiden Plate by six lengths from Gripfast and Sword Lily.

MANCHESTER November Meeting.

Friday, Nov. 2Ist. PENDLETON MAIDEN (at closing) PLATE of $£ 500$, of which second recd. $£ 75$ and third $£ 25$, for 3 yr. olds and upwards ; entr. $£ 5$. I m. 3 fur. ( 18 ents. $-£ 395$.)

Lord Glanely's b.g. Lahloo, by Santoi-

Nydian, 3 yrs., 8 st. I lb. - • - H. Jelliss I 
Lord Durham's Gripfast, 3 yrs., 8 st. II lb. - B. Carslake 2 Mr. T. Hatton's Sword Lily, 3 yrs., 8 st. I lb. J. Shatwell 3 Mr. H. Beckett's Landteel, aged, 8 st. I I lb. P. Jones Mr. R. R. Jeffrey's Toluol, 3 yrs., 8 st. 4 lb. - G. Colling Mrs. Rudd's Energy, 3 yrs., 8 st. 4 lb. - A. Whalley Capt. J. D. Cohn's Le Sund, 3 yrs., 9 st. - F. Templeman Even Gripfast, 2/1 agst. Lahloo, 7/1 Le Sund. Won by 6 lengths, bad third.

Sea Song, second favourite for the Ellesmere Handicap, giving weight to everything that started, found his $9 \mathrm{st} .8 \mathrm{lb}$. too much. On the Saturday Grand Fleet was beaten in the Manchester November Handicap, but the very last race of the season, the Final Plate, was to go to Lord Glanely, The Midshipmite greatly distinguishing himself by beating Manilardo by six lengths. Manilardo was giving $7 \mathrm{lb}$., but he had shown himself to be a really good horse. So ended the Great Year.

MANCHESTER November Meeting. Saturday, Nov. 22nd. FINAL PLATE of $£ 300$, added to a Sweepstakes of $£ 5$ each, of which second recd. $€ 50$, for $3 \mathrm{yr}$. olds and upwards. $1 \frac{1}{4} \mathrm{~m}$. (17 ents. - $\{330$.)

Lord Glanely's br.c. The Midshipmite, by

Stedfast-Favorita, 3 yrs., 8 st. 10 lb. - A. Smith ] Mr. A. R. Cox's Manilardo, 3 yrs., 9 st. 3 lb. - S. Donoghue 2

II/Io on Manilardo. Won by 6 lengths.

Forty-five races were won between the 8 th of April and the 22 nd of November, and it may be noted that to the $\{30,336$ Ios., which these stakes yielded, an 
additional $f_{1} 907$ should be added for the places they secured, making $£ 32,343$ ros. in all.

I 920

To give the history of the Great Year, together with a detailed account of the horses chiefly concerned, was the object of this book. Something may nevertheless be added of what happened during the next season. Not infrequently a lean year follows a fat one, and it was to be so here. If Lord Glanely had discovered the secret of success in 1919 it may be said to have eluded him at least to a great extent in 1920; for he won only a third in number of the races he had so triumphantly secured, and they were worth little more than a sixth part of the preceding total. No single stake amounted to frooo, and we have seen that at Ascot in I9I9 seven of them exceeded that sum. No more than a couple of the fifteen brought in half as much, in fact another example was furnished of "the glorious uncertainty of the Turf," though at the same time many owners would be far from dissatisfied if in the course of the season they won fifteen races worth $£ 5465$. It is therefore only speaking comparatively that the year can be described as a failure.

It is nevertheless true that horses started in no fewer than twenty-six races before one of them got home. Cutty Sark was beaten for the Welbeck Plate 
on the opening day at Lincoln, and Almere for the Canwick Maiden Plate. Scatwell gave hope for the belief that the stable was not out of form by running second for the Lincolnshire Handicap, as did Grand Fleet for the Liverpool Cup later in the week. But at Liverpool Skyfuse, Glenhattie, Willblend, and Sea Song all failed. Great Elm missed the Clumber Plate at Nottingham, Glenhattie made a fruitless journey to Leicester, as did Batusha. Almere tried again in the Dicker Hill Maiden Plate at Birmingham, and no good luck was in store at Newbury, where Willblend was second for the Berkshire Three-YearOld Handicap, Powerful being less conspicuous in the Spring Cup, and Polymagnus failing in the Spring Three-Year-Old Maiden Stakes. At the Craven Meeting Sea Song was beaten for the Crawfurd Plate, Lahloo for the Babraham Plate, Brilliant Jester for the Severals Stakes, and Exford for an Apprentice Plate. Somerset Lassie was not much expected for the Great Surrey Handicap at the Epsom Spring Meeting and went far to destroy her chance by a bad start. Mighty Power was beaten for the Esher Cup, and at the Newmarket First Spring Meeting Danebury, a son of Sunstar and Mira II., went down in the Two-Year-Old Stakes, as did Gwenllian in the Risby Plate, Polymagnus in the Two Thousand, Sea Song in the Bretby Stakes and Bidna in the Littlecourt Plate. Truly it was time that 
something got home, and on the 29th April The Midshipmite won the March Stakes, somewhat unexpectedly, for odds of 7 to 4 were laid on his solitary opponent, Lord Penrhyn's Perion. This had to a certain extent broken the luck, but there were several more failures before Powerful carried off the Sunningdale Welter Handicap at Kempton on the 8th May, this being the race which immediately followed the Jubilee, for which Grand Fleet ran, starting, however, at 20 to I.

More than a month elapsed before the colours were again carried to the front by Brilliant Jester, who won the Dorking Welter Handicap at Gatwick on the I I th June, and on the $25^{\text {th }}$ of that month Starshot earned $£ 855$ by taking the Duke of Cambridge Handicap at the Newmarket First July. Cutty Sark contributed $£_{4} \mathrm{I}_{2}$ on the 15 th of the same month by getting home a head for a Three-Year-Old Sweepstakes, starting favourite. And then again over a month passed before another score was made, the richest prize which fell to the colours during the season, Grand Fleet winning the Stockton Handicap worth f9 I O. The following day Sea Song landed an i i to 8 chance in the County Stand Handicap, and a little more than a fortnight later Willblend was successful at Manchester. Lorna Doon won the ninth race at Leicester on the 2oth September, Willblend following on with another the next afternoon. Great Elm was 
sent to Haydock Park and took a little stake on the 6 th of October, and on the 7 th Lord Glanely actually won twice, the Thursday Welter with Quantavis, the White Lodge Nursery with Little Jig, and on the I Ith Lorna Doon won at Wolverhampton. Willblend made a third contribution at the Newmarket Second October on the $14^{\text {th }}$ of the month, and that ended the record of the year, the record of success that is to say. It will be remembered by many readers that the Houghton Meeting of 1920 was abandoned in consequence of the Coal Strike, there having been no racing in England between the 16 th of October and the resumption at Newbury on the 5th of November. Lahloo, Sea Song, Grand Fleet and one or two others ran at Manchester, but without doing any good. 



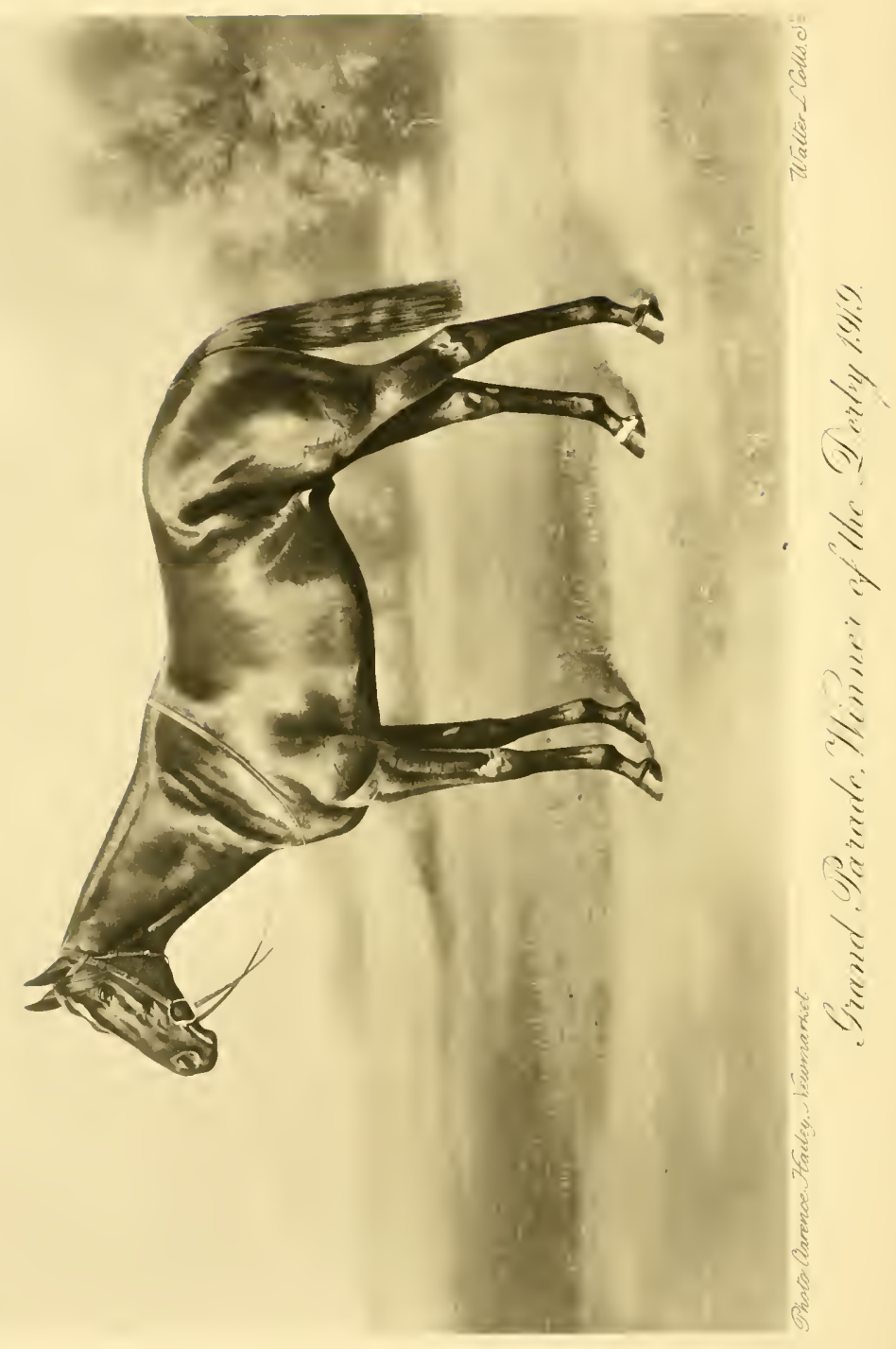




\section{CHAPTER IV \\ GRAND PARADE}

Names famous in Turf history appear as a matter of course in the pedigrees of all the thoroughbred horses of the day. But those from whom Grand Parade has descended strike one as peculiarly attractive and fascinating. Grand Parade was a son of Orby and Grand Geraldine, Orby by Orme out of Rhoda B., a mare bred in the United States of America in 1895 and imported in 1896 , a daughter of Hanover, one of the best horses in the annals of trans-Atlantic sport. Of her it will suffice to add that she throws back to Doncaster on the dam's side; for her dam Margerine was by Algerine out of Sweet Songstress, who was by the Derby winner of 1873 . We will run hastily through the descent of Grand Parade and come presently to details of his ancestors. Orme, the grandsire of Grand Parade, was a son of Ormonde and Angelica, the dam by Galopin out of St. Angela by King Tom. Ormonde was by Bend Or out of Lily Agnes by Macaroni, her dam Polly Agnes by The Cure. Bend Or was by Doncaster, 
by Stockwell by The Baron, Bend Or's dam Rouge Rose.

Grand Geraldine, "brown or black," to quote the Stud Book, was by Desmond out of Grand Marnier by Friar's Balsam out of an unnamed daughter of Galopin and Mother Superior, the dam by Sterling. Desmond was a son of St. Simon and L'Abbesse de Jouarre by Trappist out of Festive by Cardinal. It certainly cannot be considered in the least strange that Grand Parade should have won the Derby of I9I9. His sire had done so in 1907, and if his grandsire Orme had run for it, to say the least it is exceedingly probable that he would have kept up the family tradition; surely no one can imagine that Sir Hugo would ever have beaten Orme! Family tradition is certainly a correct expression, for Grand Parade's great-grandsire Ormonde won the Derby in 1886, following in the steps of his sire Bend Or in 1880 , and the last named repeated the achievement of his sire Doncaster in I 873 . Doncaster was by Stockwell, who missed the Epsom classic but won the Leger, as did no fewer than six of his offspring-St. Albans in 1860, Caller $\mathrm{Ou}$ in $186 \mathrm{I}$, The Marquess in 1862 , Blair Athol in I 864 , Lord Lyon in 1866 and his sister Achievement in 1867. Blair Athol and Lord Lyon also won the Derby. Stockwell's sire, The Baron, it may be noted, won the Leger of I 845 .

It is an overwhelming temptation to dwell on the I 26 
performances of the chief of those who have been mentioned, and to begin with we will treat Grand Parade's paternal ancestors. As a two-year-old Orby seems to have done something in home gallops which he did not repeat on the racecourse. He came out at Leopardstown in August for the Londonderry Plate, a $£ 500$ race, a not inconsiderable prize for Ireland. So good a thing was it supposed to be that odds of 3 to $\mathrm{I}$ were laid on him, and he finished third in a field of six, the race being won by a son of Bushey Park called Gleg, whose name conveys no impression to English racegoers. Three weeks later Orby reappeared for the Railway Stakes of $£ 633$ at The Curragh. This time there was a slightly better favourite in Rosetown, a son of Laveno, who, however, gave a poor exhibition. Rosetown was backed at 5 to 4 , Orby at 6 to 4 , and again he was third, beaten two lengths by Electric Rose, a daughter of Lesterlin, second being an animal who was destined to make a reputation, Silver Fowl, daughter of Wildfowler and L'Argent. Coming presently to England Silver Fowl became the dam of Fifinella, winner of the substitute Derby and Oaks, as also amongst other winners of Silver Tag, who greatly distinguished herself as a three-year-old by winning the Cambridgeshire with 8 st. 3 lb.

Attention was drawn to Orby the following season during the first week of racing, for at Liverpool he somewhat unexpectedly won the Earl of Sefton's 
Plate. There were half-a-dozen runners for it, two better favourites and one on the same mark, the race being considered a good thing for Lord Derby's Persinus, on whom odds of 6 to 4 were laid. But he could only get third to Orby and Pane, the latter of whom a couple of days before had won the Welbeck Plate at Lincoln. Orby beat him by three lengths. Subsequently he returned to his own country and won the Baldoyle Plate in May. It was stated that he would be sent over to t un for the Derby, which was not then, however, supposed to be likely to affect the result. The ground on which he was trained was declared to be altogether unsuitable for a Derby preparation, though it had served in the case of the two races which he had won. The general idea was that Captain Greer's Slieve Gallion had a comparatively easy task. He had won the Two Thousand Guineas, a performance so confidently expected of him that odds of II to 4 were laid on the son of Gallinule and Reclusion. At Epsom he started at 13 to 8 on, Major Eustace Loder's Galvani coming next in the market at 7 to I, Lord Rosebery's Bezonian, who had been second for the Two Thousand beaten three lengths, backed at 9 to I, though there could be no obvious reason why he should alter the Newmarket result. Orby and Wool Winder were both at 100 to 9, Earlston at 40 to I, All Black and Galleot at 50 to I, with a 100 to I outsider in John Bull. 


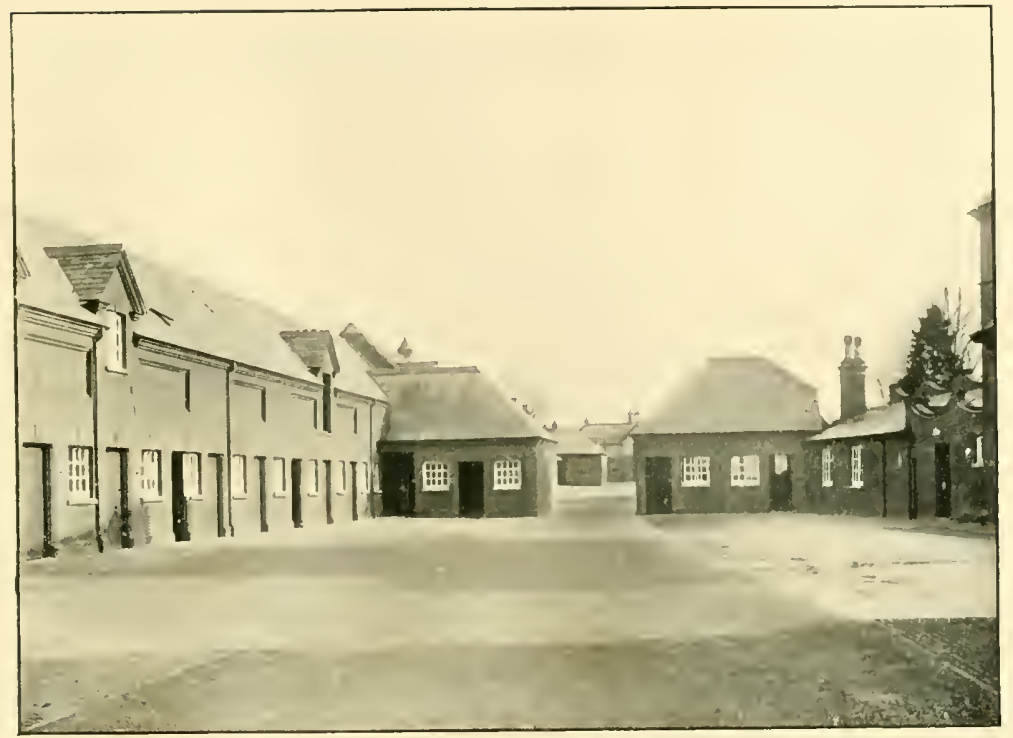

Photo: Clarence Haile?. Newmarlet

LORD GLANELY"S TRAINING STABLES NEWMARKET

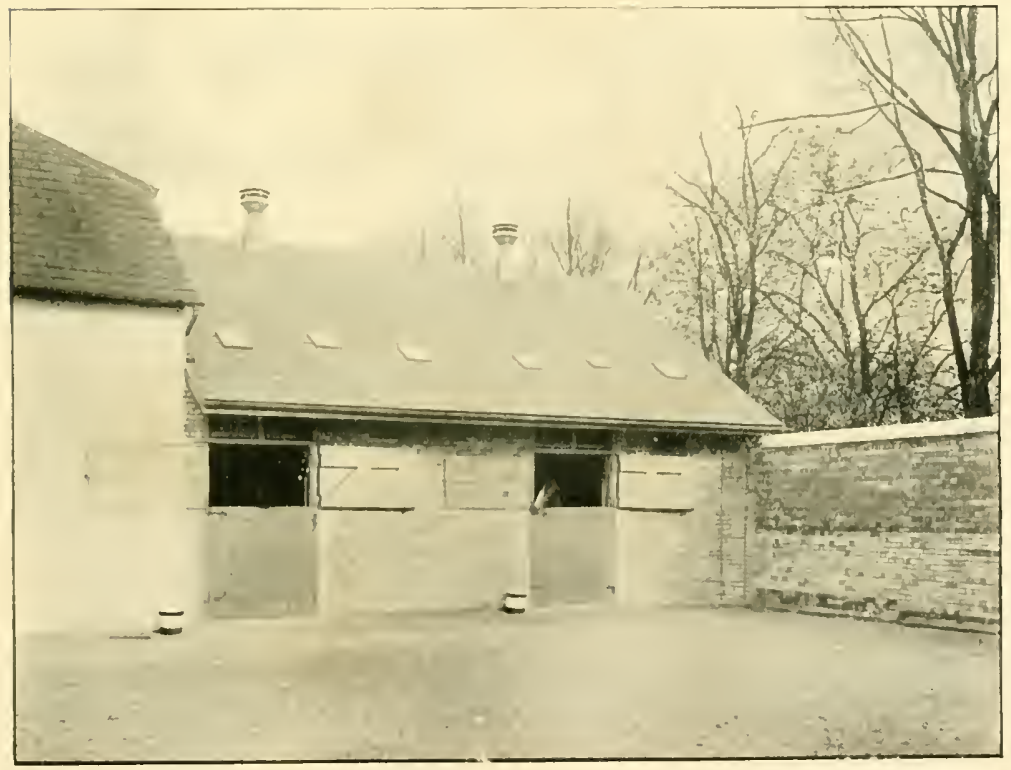

Photo: Clarence Hailey, . Veramurliet

STALLION BOXES, EXNINC 

Slieve Gallion was rather inclined to be ewe-necked and carried his head awkwardly when galloping. Higgs, who was one of the most successful jockeys of the period, and, in fact, headed the winning list that year with ${ }_{4} 46$ victories, rode the colt, as he had been accustomed to do ; but they did not get on particularly well together. There is always, however, a tendency to blame the jockey of a beaten odds on favourite, and the matter need not now be argued. J. Reiff, who had been extraordinarily successful as a light weight a few years previously, was on Orby, and won easily by a couple of lengths from Wool Winder, who beat Slieve Gallion half a length for second place. The winner returned to Ireland, where he carried off the Irish Derby from apparently a very bad field, as Io to I was laid on him, 20 to I against anything else, and it may be noted that Gleg was an indifferent third. This was Orby's last success. He came to Liverpool for the Summer Meeting, started at 7 to 4 on for the Atlantic Stakes and brought up the rear of the four runners, that having been his final appearance. At the stud he must be said to have done brilliantly, with Grand Parade as the chief of his sons.

In writing of Orby's predecessors I am naturally driven to borrow facts from John Porter's interesting autobiography, and the old Kingsclere trainer reminds us that Orme's dam, Angelica, a sister of St. Simon, was purchased by Mr. Taylor Sharp, the breeder of 
Galopin, for the trifle of 50 guineas. This was in July I 880 , long before St. Simon's capacity had been revealed. Angelica never ran, and was put to the stud as a three-year-old. Two fillies which she produced by Glendale and Cœruleus were of no account. In 1887 her colt Blue Green by Cœruleus was born and won good races; in 1889 came Orme. Porter states that when first the colt reached Kingsclere he showed great promise, winning his first trial, and duly proceeding to win races, though it may be that his greatest performance was not a victory, but when he ran the Chevalier Ginistrelli's Signorina to half a length for the Lancashire Plate at the Manchester September Meeting. The Duke of Westminster had been particularly anxious to pit Orme against his stable companion, the Baron Hirsch's La Flèche, for the Middle Park Plate. The filly, however, was not sent to Newmarket, being retired for the season after taking the Champagne Stakes at Doncaster, and with odds of I 5 to 8 on him Orme had it all his own way in the race that has been called the "Two-Year-Old Derby."

My old friend John Porter kindly allows me to borrow from the volume mentioned the account of the tragedy which befel Orme. "A few days before the Guineas Prince Adolphus of Teck, Lord Marcus Beresford (who managed the horses belonging to the Prince of Wales and Baron Hirsch) and Mr. Portal paid a visit to Kingsclere, and at stables in the afternoon 
I accompanied them round the boxes. Presently we came to Orme, who was as usual wearing a muzzle because of his habit of trying to bite the metal strips on the walls of his box. I noticed some saliva dripping from his muzzle, and after my visitors had departed went back to Orme to find out what was the matter. An examination revealed a swollen mouth.

"The first idea to enter my head was that there must be some tooth trouble, and I at once sent a telegram to Loeffler, the horse dentist at Newmarket, requesting him to come to Kingsclere. He arrived the following day, and declaring that one of Orme's incisors was diseased, extracted it. We both examined the tooth. Loeffler asserted it was diseased. With that opinion I disagreed; I satisfied myself that the tooth was perfectly sound. There was no doubt an offensive odour given off, but I protested that it was due to the decomposing food adhering to the tooth. Loeffler strongly resented the expression of my opinion, contradicting as it did his diagnosis, and he became very excited. Anyhow, the removal of the tooth brought no relief to Orme. He became indeed rapidly worse, so I summoned Mr. Williams, the veterinary professor, who hastened to Kingsclere together with his son. After a careful examination they told me that Orme had been poisoned. I had already come to the same conclusion. By now the tongue was so enlarged that Orme could swallow 
neither liquid nor solid food. All the symptoms pointed to mercurial poisoning. The hair of his coat began to come off, and before long his skin looked as though it had been shaved with a razor. For several days Orme hovered between life and death. It was almost a hopeless case. We did not leave him alone for a moment. His illness caused much excitement all over the country. The newspapers filled columns with trivial details, for reporters came in clouds to Kingsclere. The Duke of Westminster, who was naturally greatly distressed, authorised the publication of a notice which read:

\section{"ONE THOUSAND POUNDS REWARD-POISONING OF ORME}

"Whereas on the 2 Ist of April last at Kingsclere stable in the County of Hants, the racehorse Orme, the property of His Grace the Duke of Westminster, was wilfully poisoned, the above reward will be paid by the Duke of Westminster to any person who shall within one month from this date furnish such information as shall lead to the apprehension and conviction of the person or persons guilty of the said crime. Information to be furnished to Messrs. Lewis \& Lewis, Ely Place, Holborn; E.C.

"We were unable to bring the crime home to the guilty individual. I, however, had strong reason for suspecting one of my employés: but as the case 
against him was not conclusive in a legal sense I could do no more than discharge him. We found out that before Orme's illness became known to the public this man hired a horse in the village and rode into Newbury, where he met some friends at an hotel. It is believed that he there imparted as a great secret the news that the colt would not run in the Derby. Needless to say there was little difficulty in making profitable use of this information. About the time the poison must have been given to Orme our stable lads held a concert, and I was afterwards told that the man I suspected did not attend the entertainment. That might have been a mere coincidence, of course, but it certainly helped to confirm my belief that he was the culprit. Thanks to his wonderful constitution Orme managed to pull through-to that and the great probability that the ball containing the mercury did not get beyond his mouth. It was always extremely difficult to make Orme swallow a pill."

That is the end of Porter's account of the occurrence, and he claims it as the most remarkable feat he accomplished throughout his long career that three months after Orme's illness began he won the Eclipse Stakes at Sandown Park; and Porter adds that had the full strength of the gallop which took place four days before the race been generally known odds would have been assuredly laid on the son of Ormonde. He had given the five-year-old Blue Green $7 \mathrm{lb}$, and a 
six lengths beating. Many racegoers, however, not knowing this, held to the opinion that a horse who had been on the point of death so short a time previously could not beat Mr. J. H. Houldsworth's very useful Orvieto or the French colt Gouverneur-who had been second to Common for the Derby the previous season-both being strongly fancied, and certainly Orvieto made a good fight. An excuse was advanced for his defeat, it being stated that a quantity of hay, the grass having been cut just before the meeting, had been forced on to the course and had hampered Orvieto, who galloped through it; but excuses are usually futile, and Orme should be allowed full credit.

His race did him good. At Goodwood he beat his stable companion Watercress for the Sussex Stakes, and it is still a matter of controversy whether he ought or ought not to have won the Leger. On the morning of the race I went out on the course at Doncaster to see the horses at work, and lighted upon John Porter, telling him that I had backed La Flèche, and asking him whether that was a wise or a foolish proceeding? He gave me to understand that in his opinion the filly had certainly a good chance. Orme started favourite at I I to 8 on, in spite of which La Flèche stood at 7 to 2, and as history records readily disposed of her Epsom conqueror Sir Hugo-as she did on several other occasions. For the rest, Orme won the great Foal Stakes at the Newmarket First October Meeting, 
beat Orvieto by a couple of lengths for the Champion Stakes, a race in which it may be needless to say there are neither penalties nor allowances, won the Limekiln Stakes by three lengths from Colonel North's El Diablo, Sir Hugo third, won the Subscription Stakes the following day; but coming out again the next afternoon was beaten by El Diablo a length and a half, this time endeavouring to give $16 \mathrm{lb}$. Between Orme and La Flèche there could really have been very little to choose, for there is no evidence that he stayed sufficiently well to have won the Ascot Cup. In the Eclipse of 1893 the filly started favourite at evens, Orme was backed at 2 to $\mathrm{I}$ and he was successful, La Flèche third, beaten more than three lengths.

There are many who maintain that the greatgrandsire of Grand Parade, Ormonde, was the best horse the Turf has ever known. Others again would vote for St. Simon, and those are perhaps the most judicious who refrain from any attempt to make choice between them. John Porter trained Ormonde, and it may be that his view is not entirely unprejudiced. He writes: "I have often been asked for my opinion concerning the merits of St. Simon. Naturally I share the universal view that he was a very great horse; at the same time I am convinced he was no better than, if as good as, Ormonde. Neither suffered defeat. In favouring Ormonde $I$ am influenced by the 
character of the horses they met and defeated." For a horse to run through three seasons without knowing defeat is not indeed unique, though the precedents are extremely few, and there is no undefeated horse so far as I am aware who won races of such a description as those which fell to Ormonde, including the three classics. The career of Isinglass was marred by one lapse, when Raeburn, of course with an advantage in the weights, beat him at Manchester. There may have been a legitimate excuse, but the fact of the failure remains. Blair Athol went down before Miner in the Great Yorkshire Stakes, and so missed his chance of inclusion in the list of the unbeaten. Barcaldine was never beaten, it is true, and he ran for three seasons. His races, however, were not of the highest character, though he carried great weights in handicaps. He won the Northumberland Plate with 9 st. Io lb., and I would certainly say nothing detrimental to his prowess.

Barcaldine should not be denied a place in the category of great horses, and it may be incidentally remarked that he represented a triumph of skilful training. When Lord Suffolk was writing the Racing volume of the "Badminton Library" he took pains to gain information from various trainers. I came into possession of his letters and papers, and one letter was from Robert Peck describing how Fred Archer, knowing the writer's intention of buying Barcaldine, 


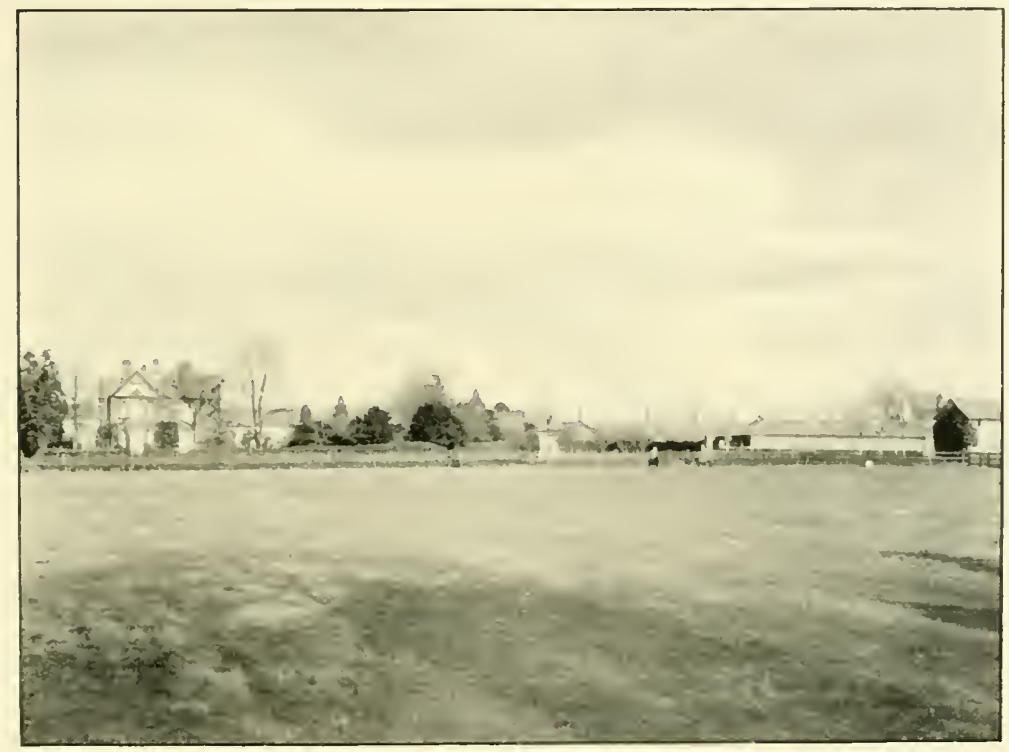

Photo: Ciarence Haile'y, S'itmarket

LORD GLANELX'S TRAINING ESTABI.ISHMEN AND PADDOCKS, NEWMARKET

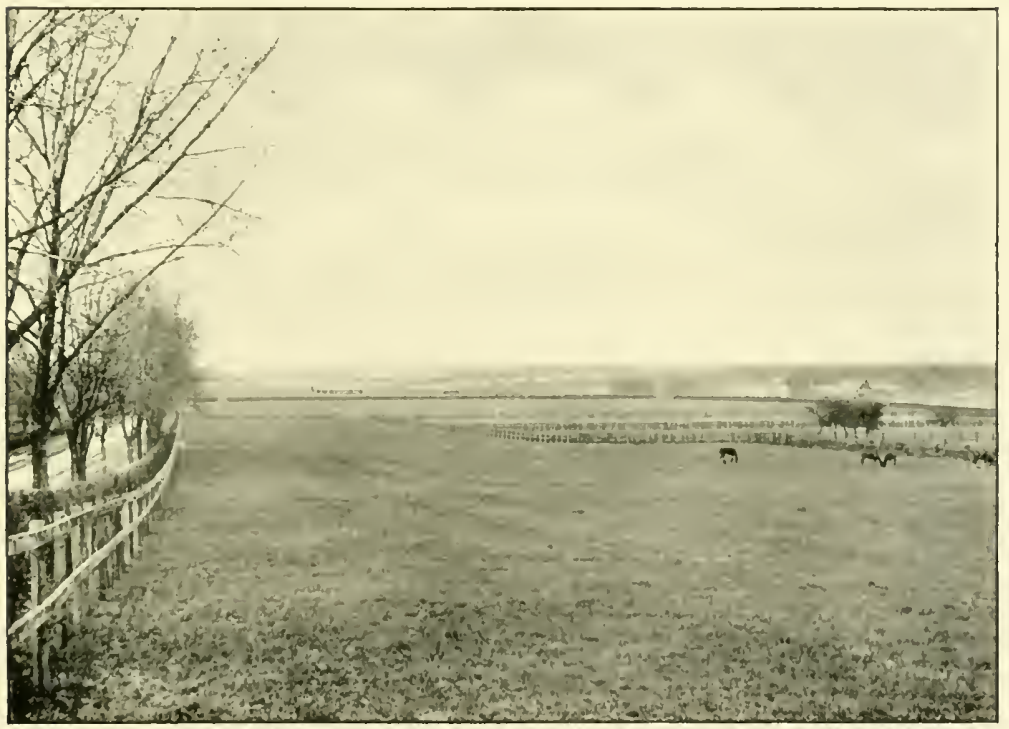

Photo: Clarence Haile! , Vermarket

THE GRAXOGE STLD FARM PADIOCKS, NEWMARKET 

begged him not to do so, declaring that he had ridden what was intended to be a gallop a short time previously when the horse " could not stride over a straw." Peck thought, however, that he could enable the horse to regain his form, as he so successfully did. It is a pity that Ormonde never ran for the Gold Cup as St. Simon had done. The son of Bend Or could not, however, do more than win every race for which he started.

Porter describes Ormonde as an abnormal foal. When he came into the world his mane was already three inches long. There were weak points about him. He stood over at the knees so much that his trainer declares he has never before or since seen a foal with that characteristic so strongly pronounced, but as soon as he began to develop on the right lines he went ahead very quickly, and when he left Eaton for Kingsclere he had the appearance of a very high-class horse. Though he was never beaten on the racecourse he failed in his first trial on the 7 th October. Kendal, then like Ormonde a two-year-old-this was in I885-with I lb. less weight beat Ormonde a length; but Whipper-in, then a six-year-old giving Ormonde I $2 \mathrm{lb}$., was beaten another length, and Whipper-in was one of the most trustworthy of trial horses. Perhaps Ormonde was not absolutely fit at this time, that is to say, on the occasion of his first gallop, and of course it brought him on. 
His trainer's description is as follows. He "was a grand looking horse. His quarters were exceptionally powerful, and though rather short his neck was the most muscular I ever saw a thoroughbred possess. He had good bone, beautifully laid shoulders, a very strong back and rather straight hocks. Although in his slow paces he had not a very taking action he was a free mover. There was immense propelling power behind the saddle. His ears were inclined to lop. The width of his head behind the ears was remarkable ;

I never came across another horse that showed this characteristic to such an extent. Ormonde had a most amicable disposition and a wonderful constitution. He was a great 'doer' and never gave us any trouble. He would eat anything the man (Marlow), who 'did ' him, offered. Cakes, apples, everything seemed to be acceptable. When galloping he carried his head rather low and covered an amazing lot of ground at each stride when extended. After Ormonde had shown himself to be a wonderful horse the Duke of Westminster, when at Kingsclere one day, rode him a couple of canters. After he had pulled up, I asked his Grace what he thought of his mount. He replied : 'I felt every moment that I was going to be shot over his head, his propelling power is so terrific.'"

There had been some idea of running him in the Middle Park Plate, but it was thought better to give him an easier task in the first instance, and he made 
his first appearance in a Post Sweepstakes over the Bretby Stakes Course at Newmarket, six furlongs. Slight odds were laid on the Duke of Portland's Modwena, a daughter of Galopin and Mowerina, who had previously won eight of ten races, the third runner being Warbler, the property of the Duke of Hamilton. Archer rode Ormonde and beat Modwena a length. At the Houghton Meeting which followed, and began on the Monday, Ormonde ran for the Criterion Stakes, which then finished at what used to be called the " Top of the Town." This he won with great ease, as he subsequently did the Dewhurst two days later, that is to say on the Wednesday, this completing his labours for the year.

It may be doubted whether there have ever been better two-year-olds than those of 1885 , the best of them according to general opinion being Mr. Vyner's Minting, a son of Lord Lyon and Mint Sauce, one of the few good horses that Lord Lyon sired. This view of Minting was not universal, there being not a few who preferred Saraband, a son of Muncaster and Highland Fling. When Saraband first came out at Kempton Tom Cannon was riding a horse of his own whom he thought possessed of a fair chance. Saraband won so easily and by so much that the famous jockey humorously expressed his belief that the winner could have completed the whole circuit of the course and then caught him. The Bard, a son 
of Petrarch and Magdalene, won all the sixteen races for which he started, and there was some idea that Prince Soltykoffs Mephisto (Robert the DevilMeg Merrilees) might be a not unsuccessful rival to the best. Bread Knife again (Craig Millar-Slice) was another of whom much was thought; doubtless he would have done better than he did had he not failed in his wind.

At the end of I 885 I edited for Messrs. Longman a book entitled The Year's Sport. The chapter on the "Two-Year-Olds of the Season" was kindly supervised by Tom Cannon, and after discussing Minting and Saraband, the remark was made: "It is impossible to get a direct line about these two and Ormonde; but from his make and shape, and the style in which he gallops, it is very likely that he may prove himself better than either." At the same time, admirably as Ormonde fulfilled all requirements, I always thought that there was a certain lack of quality about him, due perhaps to the shortness of his neck, which it will be seen his trainer admits, nor can ears with a tendency to lop be regarded as an adornment.

John Porter gives an account which is much too good to miss of what happened when he took the colt to Newmarket to run for the Two Thousand Guineas. Ormonde had not been tried; his well-being was evident and what he could do sufficiently well known. 
The Master of Kingsclere writes: "The Saturday before the Two Thousand Guineas saw Ormonde again at Newmarket. On the Sunday morning I took my horses to the Bury Hill gallops by the side of the Plantation, and there I met Matt Dawson with his string. He and I were the only trainers on that portion of the Heath. We pulled up our hacks and exchanged greetings. After the customary formalities Matt said, 'I'll show you the best horse you've ever seen in your life, John.' Thereupon he called to the boy riding Minting to come over to us. I examined the colt with critical and admiring eyes. 'Yes,' I confessed, 'he's a magnificent specimen of a racehorse.' After we had discussed Minting for quite an appreciable time, I suggested that he should have a look at Ormonde. When my candidate for the Guineas had come over for inspection, Matt looked him up and down and went all round him. Then he delivered his verdict. 'A very nice horse, very nice horse indeed,' he said, 'but mine is better here and better there.' $\mathrm{He}$ declined to admit that Ormonde compared favourably with Minting. Finally he lapsed into prophecy." "When the race is being run,' he declared, 'you will hear them shouting Ormonde and Saraband home; but when they get into the dip it will be Minting and nothing else. My horse will leave them all there, John; you will see !' 'Don't be too confident, Matt,' was my rejoinder. 
'In all probability it is in the dip that Minting himself will get left behind!' Matt smiled. It was a scornful smile. I knew he was thinking me foolish for entertaining the idea I had expressed. At that moment no amount of talking would have shaken the supreme faith he had in Minting's ability to beat his rivals in the Two Thousand or any other race."

Watts rode Minting in the Two Thousand, Archer having been secured for Saraband, and George Barrett, who may perhaps be described as a very eccentric genius, on whom it was impossible to place confident reliance though it was quite possible that he might ride brilliantly, was on Ormonde. The opinion of Matthew Dawson was held to be infallible by probably a large majority of racegoers, his belief in Minting was well known and that accounted for the colt starting favourite at I I to Io, Saraband at 3 to I, slightly preferred to Ormonde at 7 to 2. Tom Cannon was on Mephisto, who with St. Mirin, ridden by F. Barrett, stood at 100 to 3, whilst 200 to I was on offer against the Duke of Westminster's Coracle, whose mission was to make running for Ormonde if it were possible to do so, and the attempts of his jockey Viney to poach a start brought him under the severe displeasure of Lord Marcus Beresford. As a matter of fact Coracle was quite unable to perform the mission designed for him. I have a perfect recollec- 


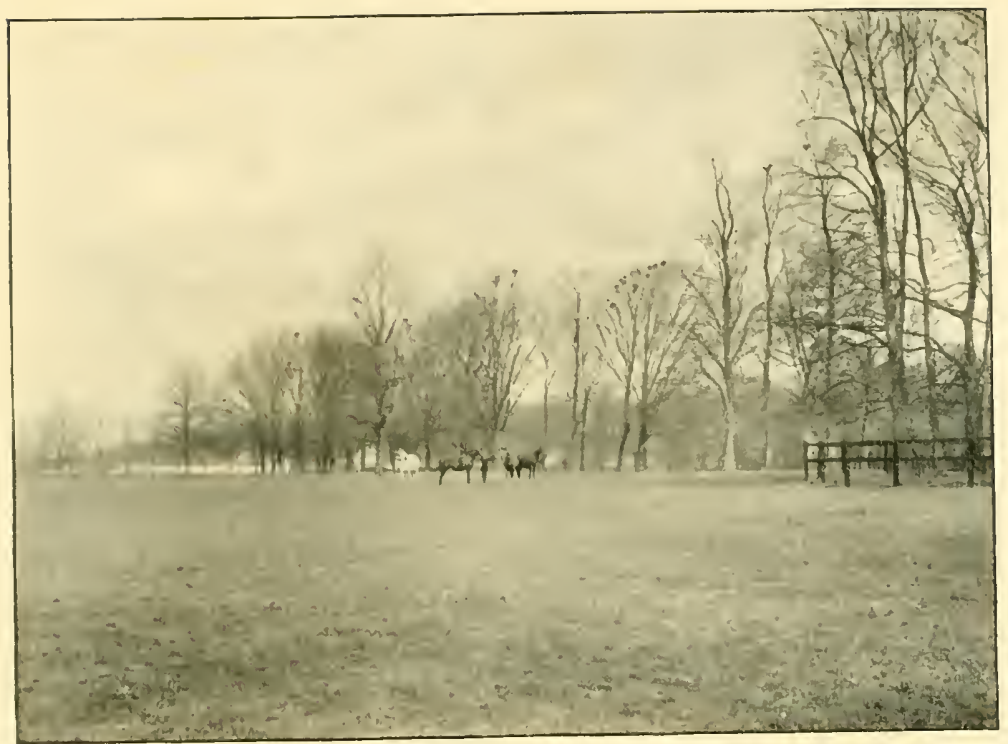

Phote: Clarence Hailey, Nemarket

WHITE HORSE PADDOCK, EXNING

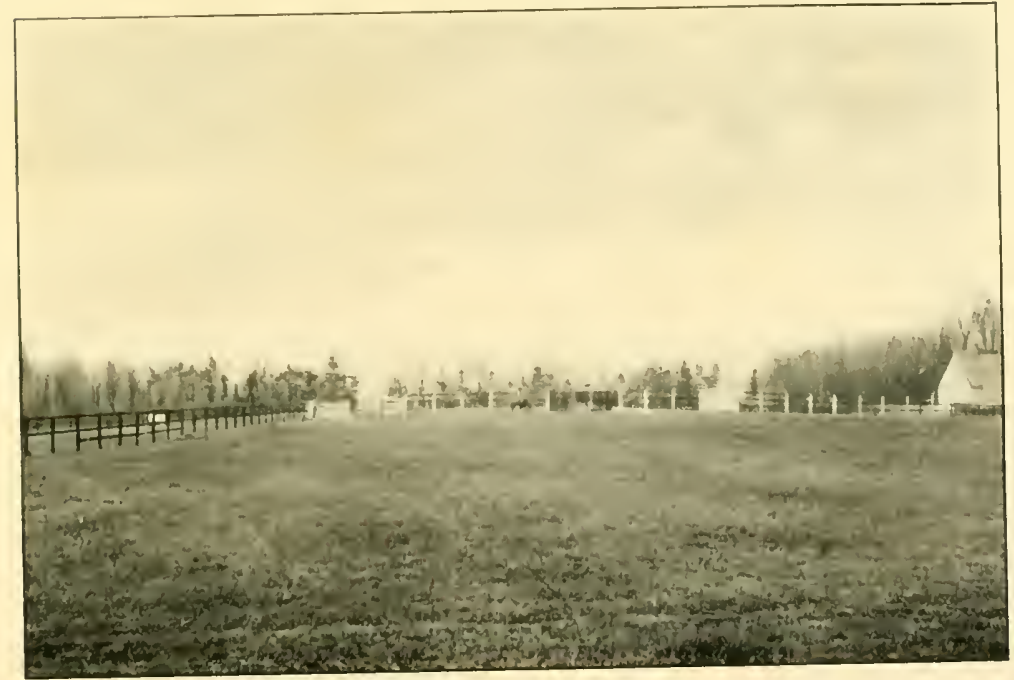

Photu: (Gurence Haile'), New'marlict

STAILION I'AJ) (IS, I:NNING 

tion of the race, which a long way from home was evidently to be between Ormonde and Minting. Descending the hill into the Abingdon Mile Bottom Minting sprawled. He was a beaten horse, and the two lengths by which Ormonde defeated him might certainly have been increased. Mephisto was a bad third. According to report Matthew Dawson went to bed and stayed there for the rest of the week. If it were not absolutely the greatest disappointment of his life he certainly can never have had a greater, and surprise was largely mingled with it.

I had been mightily struck by Minting the previous season. He was a magnificent colt and had won all his races in the most impressive fashion, but, as shown by the extract quoted from my book, I had committed myself to the choice of Ormonde as likely to prove the best of his year, and knew what John Porter thought of him, whereas I had a merely casual acquaintance with Matthew Dawson and had never heard his eulogy of his charge. Mr. Vyner, Sir J. Blundell Maple, Matthew Dawson and Robert Peck were not in the least deceived. They fully realised that to send Minting and Saraband to the post against Ormonde for the Derby was to incur defeat so far as anything can be certain on the Turf, the consequence being that neither was allowed to run for the Derby. Minting was trained for the Grand Prix, which he duly won, Saraband was kept for a Biennial at Ascot, which he had no difficulty 
in winning, and later the same afternoon he was, not very discreetly, brought out again for the Ascot Derby. Archer had ridden him in the Biennial, but was on Candlemas in the mile and a half race, Webb riding Saraband, who failed by a length and a half to give $8 \mathrm{lb}$. to St. Mirin.

Ormonde had thus established himself as a great horse, for what beating Minting in the style he did really meant was perfectly well understood, and at Epsom odds of 9 to 4 were laid on him, the only one of the other eight really backed being The Bard. About this charming little horse odds of 7 to 2 were taken, the third favourite, if so he could be called, Lord Zetland's Grey Friars, was on offer at 25 to I, St. Mirin and Mr. George Lambton's Chelsea at 40 to I, whilst I000 to I 5 could have been had about the Duke of Beaufort's Button Park and Lord Calthorpe's Scherzo, 500 to I against the Duke of Beaufort's other colt Ariel and the Duke of Westminster's Coracle. The last named was again to make running for Ormonde if he could. Some horses gain an extraordinary amount of what may be called personal popularity, and The Bard was one of them. It is not by any means always the best horse who thus takes the fancy of racegoers, and it would indeed be extremely difficult to say upon what that fancy is based. After the race for the Derby I found myself close to General Owen Williams, half owner of The 
Bard, who was affectionately patting the colt's neck, an attention which the silver ticked chestnut-there was a good deal of roan about him-seemed to appreciate, and subsequently the General informed me that he had not been altogether pleased with Charles Wood's riding. Not enough use, he thought, had been made of the colt in the early part of the race. However that may have been Ormonde's longer stride soon set the question at rest when the other reached the great horse's quarters to see if it were possible to get his head in front.

It may certainly be said that the result was never in doubt, though Archer, who was now riding Ormonde, was content to win by a length and a half. The Judge, Porter states, went so far indeed as to declare that he had never seen a race won more easily. Of course Ormonde was sent to Ascot, where he found a couple of extremely easy tasks. For the St. James's Palace Stakes against two indifferent opponents 100 to 3 was laid on him, and in the Hardwicke 100 to 30 , for here it was thought that Melton, the Derby winner of the previous year, ridden by Archer, George Barrett again on Ormonde, might conceivably make the great horse gallop. Melton it may here be said was not a particularly brilliant specimen of a Derby winner, for of other Epsom heroes St. Gatien also beat him. In the Jockey Club Cup which St. Gatien won Melton cut a somewhat indifferent figure. 
The Leger seemed a foregone conclusion. Odds of 7 to $I$ were here laid on Ormonde with Archer once more on his back, I 00 to 7 bar one, St. Mirin standing at those odds, and Ormonde won in the simplest of canters. He was sent for the Great Foal Stakes at the Newmarket First October Meeting with nothing better than Mephisto to beat; this time the odds on him were 25 to I, and nothing opposed him for the Newmarket St. Leger. It will be seen that not much money was to be made by backing Ormonde. $\mathrm{He}$ started at IOO to I on for the Champion Stakes, but for the Free Handicap it was thought just possible that he might be a little troubled to give as much as 2 st. to Mephisto, and this time it was a case of 7 to I on. Ormonde won by eight lengths. The Free Handicap mentioned is a race which used to be compiled by the Keeper of the Match Book, and had no little interest as showing the estimate of the threeyear-olds formed by a competent judge. There seems to be a tolerably common idea at the present time that the Free Handicap for Two-Year-Olds is also made by the Keeper of the Match Book, which, however, is not the case. I think it is to be regretted that the threeyear-old race has been abandoned.

John Porter proceeds in his book to relate a tragedy. He writes: "The satisfaction I derived from Ormonde's performances that year was sadly discounted by a discovery I made on the Kingsclere 146 
Downs one misty morning shortly before he won the St. Leger. As Ormonde galloped past me I heard him make a whistling noise. I was dumbfounded. The idea that the horse I almost worshipped was afficted with wind infirmity distressed me in a way I cannot describe. I hardly slept at all the following night. My mind would dwell on the fact that Ormonde had become a victim of that scourge, roaring. I at once wrote to the Duke, who was naturally deeply grieved by the news. At that period the ailment was very slight, but it gradually got worse.

"During the winter I 886-7 Ormonde was electrically treated. The electric sponge was applied every day to the paralysed nerve in his throat. The process occupied about half-an-hour. At first Ormonde did not take at all kindly to this doctoring, but he speedily became accustomed to it and took no notice. I have reason to think he derived no benefit from the treatment; nevertheless we persevered, for there seemed to be no other remedy to try. When Ormonde resumed work in the Spring of 1887 he had become a pronounced whistler. One morning when there was a thick fog on the downs we could hear him breathing when he was nearly half a mile away. Of course, the fog helped to carry and magnify the noise. The Duke, who was with me, remarked sadly, 'I am afraid there is not much doubt about it now !'

"As a four-year-old he was galloped a mile the 
week before Ascot, and showed that, roarer as he was, the infirmity had little affected him; for he gave the three-year-old Spot 3 st. $7 \mathrm{lb}$. and a two lengths beating, St. Mirin, running Ormonde at even weights, six lengths behind the second; and as at Ascot a few days later St. Mirin receiving Io lb. ran Minting to a length, with Bendigo a bad third, it was evident that Ormonde was something like himself."

As a four-year-old Tom Cannon was Ormonde's jockey and rode him for the first time in the Rous Memorial. One of his opponents was Captain Machell's Kilwarlin, who was destined to win the coming Leger. Ormonde had to give the three-yearold 25 lb., and the Captain-there were many other captains on racecourses but Machell was always "the " Captain — vowed that no horse ever foaled could do so. Ormonde won easily by six lengths, and being asked what he thought of the horse, the Captain replied, "Ormonde is not a horse at all, he is a damned steam engine!"

Next day came the famous race for the Hardwicke Stakes. Of course by this time it was well known that Ormonde made a noise, and again Matthew Dawson was confident of success, feeling certain that no horse suffering from the ailment which had overtaken Ormonde could hope to beat Minting. Mr. Hedworth Barclay's Bendigo and Mr. H. T. Fenwick's three-year-old Phil were also runners, and Porter 
confesses that for the first time he had no great confidence in Ormonde, not knowing how his wind trouble would affect him over a mile and a half-the Rous Memorial is only a mile-with a pull up hill in the last mile. John Porter takes us behind the scenes to explain why Ormonde's performance was really a much greater one than it looks on paper. "George Barrett was jealous," he writes, "because Cannon was engaged to ride Ormonde. He rode Phil, and coming round the bend into the straight bored his horse on to Cannon's mount, indeed for a considerable distance Ormonde was practically carrying Phil. After the race we found that Ormonde's skin was grazed for three or four inches down the side of his near hind leg. That was when Phil had struck into him. Cannon was, it will be understood, unable to make as much use of Ormonde as he could and would have done but for the disgraceful tactics pursued by Barrett. When he returned to the paddock Cannon was very indignant. It had taken Ormonde all his time to win by a neck. "The excitement was tremendous. When Ormonde passed the post the thousands congregated on the Stands and in the Enclosures were cheering their loudest, the ladies waving handkerchiefs. The Duke was the proudest man in the world at that moment, and I was a good second to him. For a long time I could not get to Ormonde, so great was the crush around him. After the 'All right' had been 
called the Duke led the horse twice round the paddock, and then walked him on to the course on the way towards the stables. He seemed loath to leave go of the leading rein. It was the greatest display of enthusiasm I have ever seen on a racecourse."

It will be perceived that Porter states it had taken Ormonde all his time to win by a neck. I well recall a conversation with Tom Cannon when he emerged from the weighing room. Someone came to congratulate him on the great race he had ridden, commenting on the desperate finish and the fear that Ormonde might not be able quite to last home. When the enthusiast had moved away Cannon remarked to me that "it had not been as close a thing as that," and certainly gave me to understand that he had never felt in anything like a desperate state of anxiety about the result. I published his precise words at the time, but we are talking of five and thirty years ago, and I am afraid that it would be impossible to find a copy of the paper in order to quote them accurately.

Ormonde was to appear only once more, for a six furlong race at the Newmarket July Meeting-the Imperial Gold Cup. A speedy horse called White Friar belonging to Sir George Chetwynd was one of the three runners, but Ormonde disposed of him, though it may be admitted there was a time in the race when it did not look 100 to 3 on the winner, that being the price at which he started. In all Ormonde won 
fifteen races, nine of them at Newmarket, four at Ascot, one at Epsom and one at Doncaster, earning in stakes $£_{27,266}$ Ios. So much for Grand Parade's great-grandsire.

If there were any lack of quality in Ormonde, there was, as I recall him, none in his sire Bend Or. The story of the Derby of $\mathrm{I} 880$ has been told so often that it must not be repeated at length. I had an excellent view of the finish, and can still see Archer on the beautiful chestnut coming with a desperate rush, whilst Rossiter on Robert the Devil seemed absolutely to shrink. Bend Or won by a short head. If the jockeys had been reversed the Duke of Westminster's colt would surely have been beaten several heads. It would be waste of time to speculate upon the question what was Bend Or's best distance? At any rate he did not stay as well as Robert the Devil. He could not, however, have given his running in the St. James's Palace Stakes at Ascot, where over the Old Mile he merely beat Fernandez a head, and that was the only other race he won that season; for though odds of I I to 8 were laid on him in the Leger he was never dangerous, Robert the Devil winning in a canter. Bend Or was beaten again in the Second Great Foal Stakes at the Newmarket First October, Robert the Devil, ridden by Tom Cannon, having a head the better of him, Archer in the Duke's yellow jacket; and Robert the Devil beat him yet once more in the 
Champion Stakes by ten lengths, Robert ridden by his Epsom jockey, Bend Or this time by George Fordham.

As a four-year-old Bend Or did well, leading off by winning the City and Suburban by a length and a half from the three-year-old Foxhall in receipt of $34 \mathrm{lb}$., an extraordinary performance if Foxhall had been anything like himself, which may be doubted. Bend Or and Robert the Devil met again over the Derby course for the Epsom Gold Cup, a race which, however, really proved little. Bend Or was here certainly by no means at his best, having done very little work, indeed I believe he was sent to Epsom with an idea that if he appeared there he would be allowed to walk over. Robert " had a leg." I remember Tom Cannon telling me that he had gone with the colt's owner and trainer to look at him in his box the evening before the race, and had felt the doubtful joint, which Robert was disposed to put up into the manger or anywhere else where it could not be touched. Odds of 6 to 4 were laid on Robert nevertheless, and Bend Or beat him a neck. He won the Champion Stakes from Scobell and Iroquois, the American colt who it need hardly be remarked had won the Derby and Leger of that season, and he started favourite for the Cambridgeshire, ridden by Archer and carrying 9 st. $8 \mathrm{lb}$.

But this was when Foxhall gave his great performance, winning the race after a desperate finish by 
a short head from Lucy Glitters, who had been second for the Oaks and for the Leger, giving her, they both being three-year-olds, $35 \mathrm{lb}$. Most people imagined that 9 st. was prohibitive weight for a three-year-old. This was of course before Robert the Devil had won the Cesarewitch with 8 st. 6 lb., and St. Gatien had exceeded that exploit by winning easily with 8 st. Io lb. on his back. At this date I happened to have a share in a horse in William Day's stable, where Foxhall was trained, and had gathered from the old trainer that he anticipated the colt's victory. One of the most brilliant fields that ever ran for the Cambridgeshire assembled for it, containing as it did Tristan, Peter, Petronel, winner of the Two Thousand, Elizabeth, winner of the One Thousand, Corrie Roy, Incendiary, Toastmaster, Prestonpans, Poulet, and others famous animals. It was unfortunate that Bend Or did so badly, as this was his last race.

Doncaster, sire of Bend Or, won the Derby in 1873 in then inexperienced hands. Mr. James Merry, his owner, does not seem to have provided himself with a jockey and secured the services of Fred Webb, who was destined afterwards to make a great name for himself; he was not only absolutely in the first flight, but may be said to have had scarcely a superior. The colt was victorious in his youthful hands and came within a short head of winning the Leger, which that year was a peculiarly exciting 
contest. Mr. James Merry had also won the Oaks with Marie Stuart, and when the Doncaster Meeting came round it still remained doubtful whether the classic colt or the classic filly was the better. Their owner determined to let them fight it out, as they did, the result being as nearly as possible a dead heat, though Marie Stuart in the hands of T. Osbornewhose death was recorded whilst this chapter was being written-had a short head the better of it. The sire of Doncaster, Stockwell, has been already mentioned. Among Lord Glanely's sporting pictures is one by Herring of Pocahontas with Stockwell when a foal at her side. Stockwell's sire, the Baron, did not win the Derby, but in 1845 he was victorious on the Doncaster Town Moor. Considerations of space render it impossible to trace the parentage of Lord Glanely's colt to a more remote period, for we still have to consider his breeding on the dam's side.

Grand Geraldine, as mentioned on a previous page, was a daughter of Desmond and Grand Marnier, who was by Friar's Balsam, granddam by Galopin out of Mother Superior by Sterling; so that on both sides Grand Parade is rich in the bluest blood known in racing history. It is one of the best recognised facts in connection with racing that what a mare does when in training affords no clue to what she is likely to accomplish when sent to the paddocks. Many of the most brilliant performers, winners of not only the 
chief races reserved for fillies but of those in which they meet the other sex, have been complete failures in after life, while dozens of instances could be cited of mares who have been useless when in training but have become the dams of many of the best horses in the Stud Book. As a racehorse Grand Geraldine was of no account. Bred in 1905 she ran once as the twoyear-old, in the Scurry Plate for all ages at the Curragh and finished in the ruck. It was evidently perceived that she was unlikely to win races. She was withdrawn in consequence, and, sent to The Gull, produced in I 909 a chestnut filly named Gerenda who did no better than her mother had done. She ran once, for the Dublin Plate at Leopardstown, and that is all there is to be said about her. Sent to Orby next season a colt named Howard O'Carroll was the result. He never ran, nor did Oakland, another elder brother of Lord Glanely's famous colt.

In I9I 2 Grand Geraldine was barren, but in I9I 3 she produced Ybro, the first of the family who seemed to have any capacity for galloping. He only ran once as a two-year-old, when he started favourite for the Bray Plate at 2 to I and finished third to Mr. J. Nugent's Royal Scots. As a three-year-old Ybro was out on eight occasions and won the Newbridge Plate at the Curragh for $\mathrm{Mr}$. Croker from the second favourite, Mr. R. B. Dobell's White Abbey, Lady Torrington's Hartstown a short head behind. White 
Abbey, however, was giving 2 stone, so that Ybro's performance does not amount to much. As a fouryear-old Donoghue rode him in the Stewards' Plate at Baldoyle and finished down the course.

In the year r 916 a daughter of Grand Geraldine by Dinneford named Geraldina did something to compensate for the previous poor results of her dam's unions. When she came out at Leopardstown for the Stillorgan Two-Year-Old Plate she was evidently " not expected," for odds at 20 to I were on offer against her in a field of six, the race going to Foulmartlaw, who won a number of stakes for Capt. Percy Bewicke. Then, however, Geraldina began to assert herself. Odds of I I to 8 were laid on her for the Liffey Bank Plate at Phœnix Park in a field of two dozen and she won comfortably. Three days later, odds of 9 to 4 being laid on her this time, she won the Lee Plate at Cork Park by fifteen lengths, though we may assume that she had nothing to beat; but in the Nursery Stakes at the Curragh her task was evidently considered to be a somewhat serious one as 3 to I was laid against her. She won, however, by eight lengths. This Nursery took place in June, which will strike the English racegoer as odd. I must confess to complete ignorance of racing in Ireland and note that there was only a difference of I I $\mathrm{lb}$. between the seven starters. Geraldina let down her supporters at the Curragh in July, when with odds of 2 to I on her she was beaten 156 



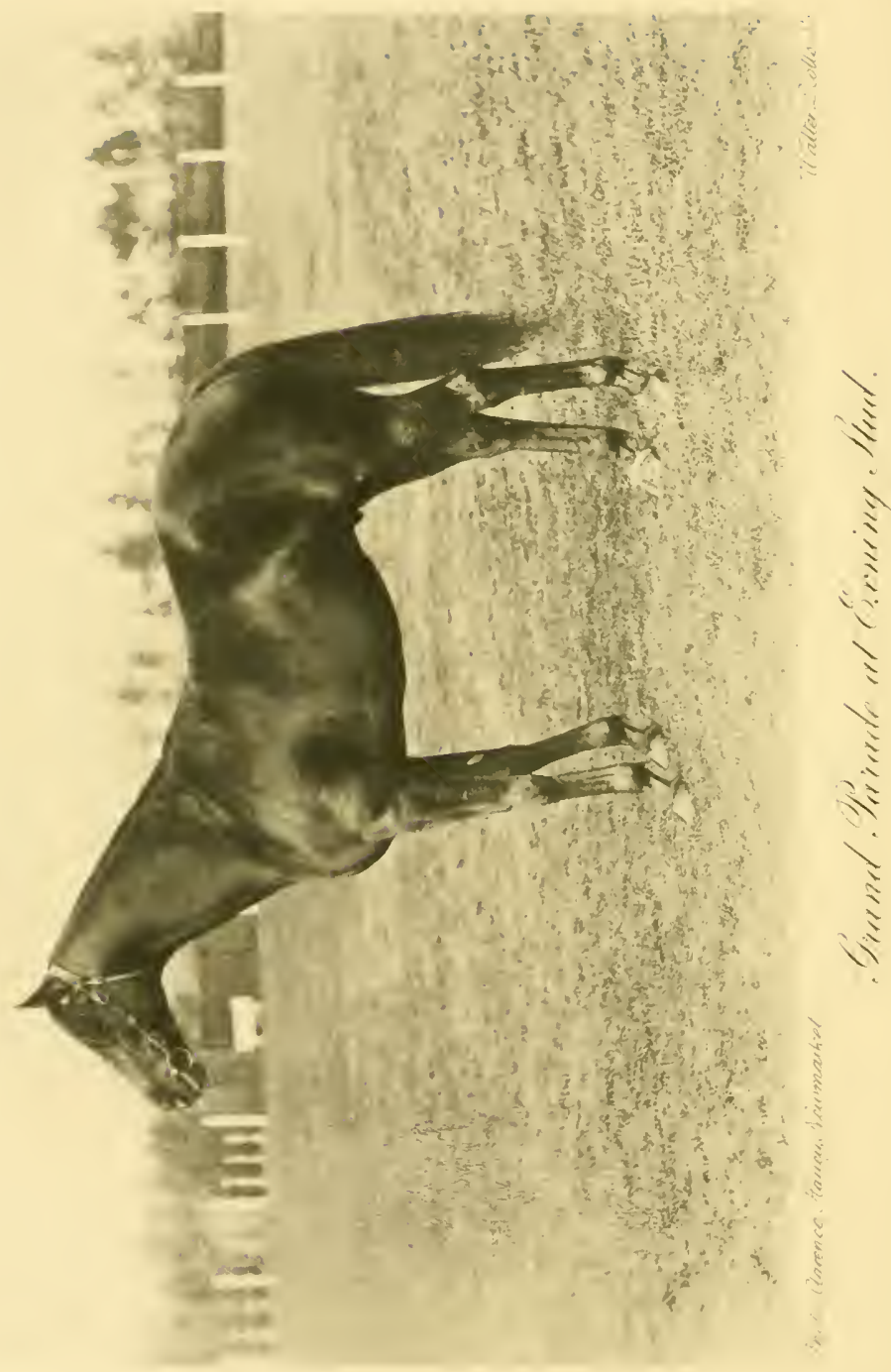


a length and a half at even weights by Certosa-diPavia, and for the comparatively valuable Railway Stakes at the Curragh in September she finished third. As a three-year-old Geraldina did not reproduce her earlier form, failing in all her five attempts, but as a four-year-old she did better, carrying off the Brownstown Plate and the Scurry Handicap, both at the Curragh.

Of Grand Parade, her next son, I shall speak in the next chapter. At present we will glance at Grand Geraldine's descent. As already noted, she was a daughter of Desmond and Grand Marnier. Desmond, son of St. Simon and L'Abbesse de Jouarre, was a good horse when he cared to display his capacity, but best known for his exploits at the stud, where in the year I 9 I 3 he headed the list of winning sires, frequently having been near the top. Desmond, the property of Lord Dunraven, was ready early in the season, which was perhaps on the whole not a good augury, for it is generally understood-Lord Suffolk summarises the observation-that the Brocklesby Stakes form is apt to come out at the end of the season some two stone behind the Middle Park form. This was written a great many years ago, but that it remains true appears from the fact that the Brocklesby of 1920 , the year in which this book was begun, went to Napolyon who, of course, carried 9 st. and in the Free Handicap for Two-Year-Olds was allotted 7 st. I lb., 
whilst Monarch, winner of the Middle Park, is awarded 9 st. Desmond was nearly favourite for the Lincoln race, starting at 9 to 2 and finishing second to a very slightly better favourite in Amurath, 4 to I. Lord Dunraven's colt progressed satisfactorily, so much so that odds of 5 to 4 were laid on him for the Woodcote Stakes and as nearly as possible landed, Fairy Gold beating him a short head. The Summer Breeders' Foal Plate at Manchester was the first of Desmond's victories. Backers evidently thought the Woodcote form good enough and laid 5 to 4 on him again, with happier results than had been experienced at Epsom. For the Coventry Stakes that year Captain Machell sent out a hot favourite in Blackwing. When it became known that the Captain fancied anything a very short price was inevitable. Blackwing started at 9 to 4 on, but could only get third, Desmond winning at 4 to I from Melfi. Lord Dunraven's dark blue, yellow chevrons, sleeves and cap, were then landed in the July Stakes. A filly belonging to the Prince of Wales, Eventail, was much expected to win, no more than I I to Io being obtainable above her, though there was plenty of money for Desmond, who started at I 3 to 8 and won by a neck. A colt with this record, for Woodcote, Coventry, and July are races the winners of which have seldom failed to distinguish themselves subsequently, as a matter of course raised high hopes, and it would seem curious that he never won another 
race were it not that it was understood his temper in all probability prevented him from doing so. He ran well for the Champagne, indeed, starting at 5 to 4 and finishing third to Mr. Willie Low's Mark For'ard and Mr. Douglas Baird's Musa, the filly who won the Oaks next season. Mark For'ard won by three parts of a length, Desmond a neck behind the second. $\mathrm{He}$ started for the Dewhurst, but as the phrase runs, had nothing to do with the finish, the race going to Frontier ridden by Morny Cannon, who beat Sloan on Caiman, the latter a hot favourite I I to 8 on.

As a three-year-old Desmond's contemporary, Flying Fox, stood continually in the way. Desmond's reputation was, however, by this time almost destroyed, a remark which seems justified when it is noted that odds of 40 to I were laid against him for the Two Thousand Guineas. The idea was then conceived of giving the colt an easy task to encourage him, sending him for a race in which he would have little to do. A Welter Handicap at Newmarket was selected. This time he was ridden by Sloan and started at even money, but he finished in the ruck. For the Derby he was a hopeless outsider, Flying Fox a 5 to 2 on chance. At Ascot he tried his luck in the Rous Memorial. This was another of the duels which frequently took place between Sloan and Morny Cannon, and here the English jockey had the better of it. Odds of 5 to 4 were laid on Dominie II., who was beaten by Champ de 
Mars. Desmond made one more appearance, in the Sandown Foal Stakes, when he confirmed the impression that it was time to withdraw him from training.

His offspring soon began to show promise, and his original fee of 25 guineas was raised to 35 guineas in I 904, when he was announced as full. A filly called Isalian Beauty was the first of his stock to make a mark, as she did by winning the Free Handicap for which that season there was an altogether unusual field of seventeen. In 1905 nineteen of his children won 38 races between them, Earla Mor, Athi, Land League and The White Knight prominent among them. A couple of years later we find him with $6_{3}$ races to the credit of his young ones. Saxham and Sir Archibald were two who helped his score. Charles O'Malley, Desmond's Pride and Declare came soon afterwards, followed by Hall Cross, Combination, Knockfeerna and Lomond. Fairy King, Stornoway, Craganour, Aboyeur, Glorvina and Hapsburg helped to give him supremacy in the list of winning sires, and by this time his fee had increased to 250 guineas. It may be noted as strange, by the way, that Craganour and Aboyeur who finished with only a head between them for the Derby should both have been sons of Desmond.

I think it was the following season, I9I3, that I watched the Grand Prix in company with Lord Dunraven, who at the time was not aware of the unfortunate 
fact that Desmond had been found dead in his box. His owner had contemplated raising the fee to 300 guineas. So much for the sire of Grand Geraldine.

Desmond, to pursue the sire line, was a son of Friar's Balsam and an unnamed mare by GalopinMother Superior, and for the record of Friar's Balsam, son of Hermit and Flower of Dorset I must turn again to John Porter's book. The old Kingsclere trainer writes: "I may state right away that I regarded Friar's Balsam as a smasher." About that there can be no difference of opinion. John Porter himself at this time owned a smart filly named Mon Droit by Isonomy-In Bounds. At the Newmarket Second Spring Meeting she had won a two-year-old stake in a canter by four lengths, and in a gallop with Tom Cannon up Friar's Balsam gave Mon Droit a stone and a very easy beating, a couple more two-year-olds with light weights finishing in the rear.

I may perhaps diverge to note that Mon Droit not long afterwards beat a good colt named Anarch at Windsor, though there was some suspicion that she may not have done so on her merits. At this period there was a " plunger" who acted on a "system." For systems in general I have the greatest contempt, for one reason because without exception they all lose money for their followers, and for another because they seem so thoroughly opposed to the spirit of sport. This system, however, was really based on an excellent 
idea with one difficulty about it. The idea was to back nothing but certainties, the trouble being to make sure that they were what they were supposed to be. On the Turf the greatest certainty is sometimes proved to be uncertain. The plunger in this case wired up to a prominent book-maker to put him $£$ I 0,000 on Anarch. The telegram arrived before mid-day and the race was fixed for 3 o'clock. What happened meantime is not known, but Anarch did not land the long odds that were laid on him. Perhaps he ought to have done so. "De mortuis "

It has been the custom of many owners to bring out their best two-year-olds for the New Stakes at Ascot, and it was for this race that Friar's Balsam first carried silk. The circumstance is impressed upon my mind as I travelled down to Ascot with a friend, now General Sir Cecil Bingham, who had heard of the wonderful Kingsclere trial, information of which had also reached me, and we agreed that we could not believe it. Our incredulity, as it presently appeared, was ill-advised. In the New Stakes that year there was a good colt and a good filly, the Duke of Portland's Ayrshire and Lord Calthorpe's Seabreeze. They had both won races and each was expected to win this one. Ayrshire, it need hardly be observed, won the Two Thousand and the Derby, amongst other events which made him one of the richest winners in Turf annals. Seabreeze beat him in the Leger, indeed these two were in frequent 


\section{GRAND PARADE}

opposition with varying results. But Friar's Balsam cantered away from them, beating the filly by three lengths, Ayrshire a bad third. He won the Hurstbourne Stakes at Stockbridge, in which, however, he had not very much to beat, again disposed of Seabreeze in the July Stakes, had such an easy task in the Richmond Stakes at Goodwood that odds of 25 to I were laid on him, and for the Molecomb he was allowed to walk over. The Middle Park he also took in a canter from a chestnut colt with an extraordinary amount of white about his legs named Hazelhatch, Seabreeze third; and he won the Dewhurst at roo to 3 on.

Nothing was more evident than that he ought to have won the Two Thousand Guineas. A friend of mine, who had backed him for a great deal of money, laid another 3000 to 1000 on him as he went to the post. Here Porter shall describe what happened :

"To our utter dismay, Friar's Balsam made no show in the race, and finished fifth of the six runners. Not until he returned to the paddock did we know there was anything wrong with him, but we then found his mouth full of pus. An unsuspected abscess had burst while he was racing. I immediately telegraphed to London for Mr. Williams, the veterinary surgeon, who eventually removed a piece of loose bone from the jaw.

"Friar's Balsam was a very difficult horse to dress in the stable, he was so restless. When this operation 


\section{A GREAT YEAR}

had to be performed we used to put a Chifney bit in his mouth to keep him under control. A single rein was attached to the under portion of the bit, and the man 'doing' him held the rein in his hand. When dressing a part of the body that was not sensitive, the attendant would throw the rein over the horse's back. I have always thought that one day shortly before the Two Thousand the man allowed the rein to hang loose on the ground, and that Friar's Balsam, stepping on it, pulled it taut with a jerk and so injured his jaw. The remarkable thing is that the horse had not, prior to the race, by refusing his food or in some other way, given an indication that there was anything the matter with his mouth.

" The wretched abscess pulled Friar's Balsam down sadly, and it was not until the autumn that I had him fit enough to race again. He competed for the Lancashire Plate of $£_{\mathrm{I} I}, 000$ at Manchester in September, but was unplaced behind Seabreeze and Ayrshire, both of whom he defeated so easily the previous year. Three weeks later, however, he was himself again, and caused a sensation by winning the Champion Stakes at Newmarket; for odds of Ioo to 60 had been laid on Minting, who was beaten half a length by the son of Hermit."

For the Lancashire Plate Seabreeze was favourite at 5 to 2, Ayrshire following at 5 to $\mathrm{I}$, and third to them was the French colt Le Sancy, who peopled the 
French Turf with grey horses. Indeed, he may be said to have done the same for the English turf, for his son Le Samaritain was the sire of Roi Hérode, the sire of The Tetrarch. For the Royal Stakes at Kempton Park, of which Porter speaks, the Duke of Portland ran two colts, Melanion, who started at 100 to 30 , and Ayrshire 6 to I, whilst it may be noted that this time Seabreeze stood at Io to I. A friend of the Duke of Portland had taken 6000 to I000 about Ayrshire before he heard that Melanion was the fancied one of the pair, a statement which the Duke confirmed. Obviously, as it seemed, the backer had made a mistake, and he gave Fry the book-maker $£ 50$ to transfer the bet to Melanion, thus losing $£$ IO5O instead of winning $£ 6000$. Friar's Balsam was favourite at 5 to 4 on, but he had lost his form, as was proved further by a gallop soon after he reached home, and he never ran again, nor was his stock anything like what there had seemed reason to anticipate, though his son Friar Tuck was third for the Derby, Balsamo won the City and Suburban amongst other races, Sterling Balm, Sermon, and some others were winners. Happily a share of his quality, super-excellent when himself, has been transmitted to Grand Parade.

Friar's Balsam's sire Hermit is one of the most famous of horses, not indeed by reason of exceptional capacity when in training-his great reputation was made at the stud-for his record of failures is an 
extensive one, but in consequence of his having carried an enormous amount of money in the Derby, and the association of the leading owners of the period with his sensational victory. The Duke of Hamilton laid the Captain I 80,000 to 6000 against the colt, though the bet was scratched. I have in my possession a copy of a letter from the Captain stating the fact. What the Marquess of Hastings lost is not on record. Hermit had broken a blood-vessel shortly before the Derby and consequently been stopped in his work, so that he drifted out in the market to hopeless odds, or rather it should be said to odds which were apparently hopeless, seeing that the 66 to I chance fructified.

It is astonishing, by the way, to find a judge who is trying a case in connection with racing knowing anything about the Turf. A few years ago I went to the Lewes Assizes to give evidence as to the value of a horse that had been killed by a motor 'bus. Counsel for the Plaintiff, Mr. Kennedy Jones, dilated on the breeding of the equine victim. He was, Sir Henry Dickens remarked, descended from "the famous Hermit who won the Derby in a snowstorm. I cannot, I am afraid, give you the exact date of this occurrence, gentlemen," he observed to the jury, when the Judge, Mr. Justice Bray, leaned over his desk and remarked, "It was in I 867." Hermit, however, who thus comes into our story as an ancestor of Grand Parade, was a son of Newminster, who won the St. 


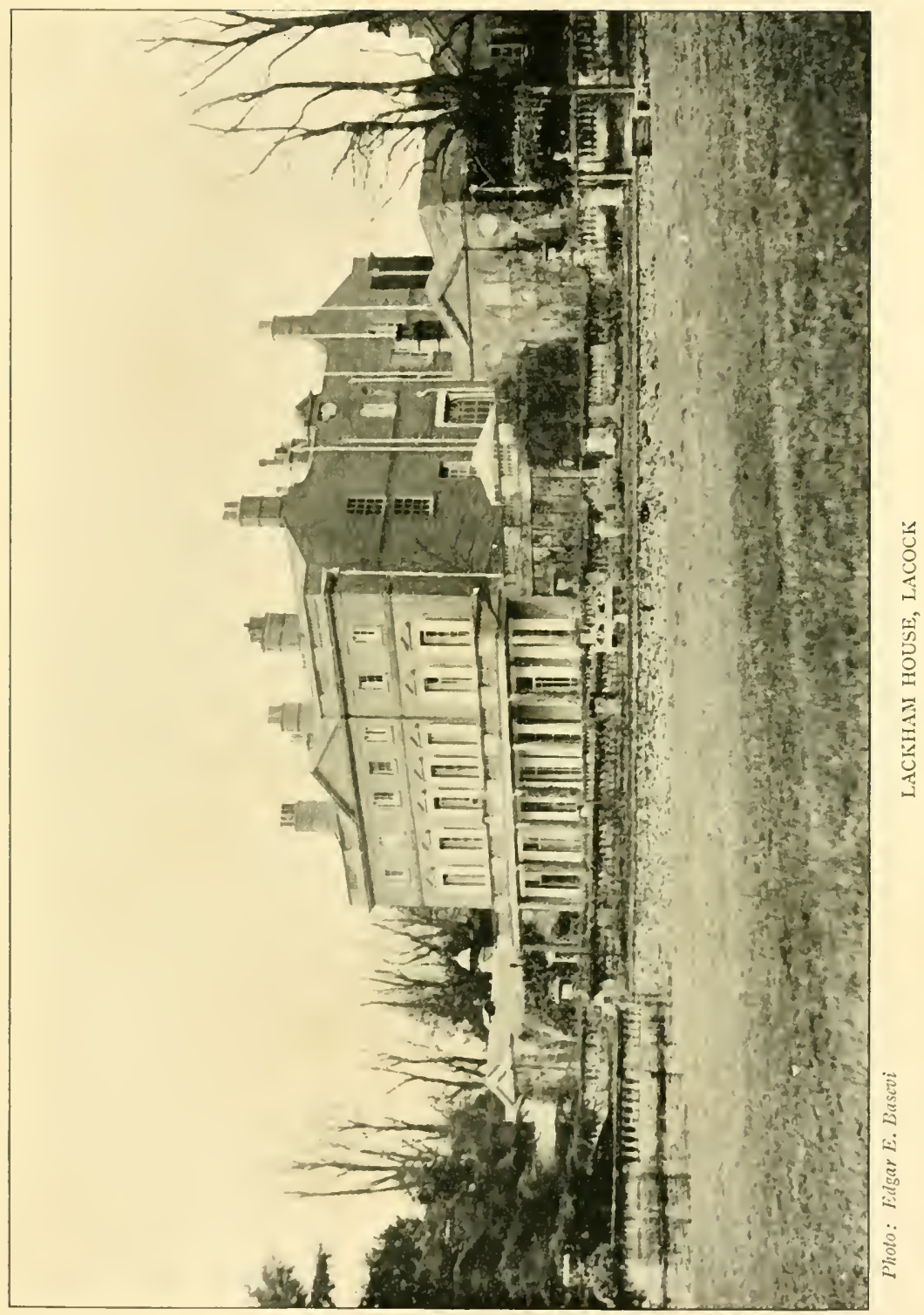



Leger of $186 \mathrm{I}$, by Touchstone, another of the greatest names in Turf history, who won the Leger of I 834 and sired a number of great winners, classic ones among them including Cotherstone, Flatcatcher, Nunykirk, Lord of the Isles, Mendicant, Blue Bonnet and Surplice. Also Orlando, who was credited with the Derby of 1844 after what is perhaps the most sensational episode in the history of the Blue Ribbon. Orlando was beaten by a horse falsely described as Running Rain who was subsequently proved to be a four-year-old called Maccabæus, a name afterwards changed to Zanoni.

Grand Marnier, the property of Lord Hamilton of Dalzell, came out for the Lincoln Plate of 1902 one of eleven starters. Something was hoped of her, for Morny Cannon was engaged to ride and she was backed at I00 to I 5, Captain Machell's Lady Help starting at the same price, whilst Mr. Leopold de Rothschild's Cormac and Mr. S. R. Fry's Acquisition were joint favourites at 9 to 4. Lady Help won easily, Grand Marnier fourth. This was considered encouragement for the owner to take 5 to I about his filly for the Grove Park Two-Year-Old Stakes at Warwick, won by Lord Dunraven's Salute. Lord Hamilton has done more than anyone to strengthen and revive the Scottish Meetings, and we find Grand Marnier at Hamilton Park running for the Bothwell Nursery Plate well backed at 9 to 4 , with, however, 
an unnamed son of Sempronius and Lady Smith on the same mark and Roseburn at 7 to 4 . Grand Marnier finished third of the seven, beaten, however, ten lengths. For the Salisbury Stakes she stood at I 00 to 8 and ran accordingly, not coming out again till the end of October, when she ran for a Selling Nursery at Sandown, making no show, and she did no better in the Stratford Welter at Warwick. Evidently she was no use for racing and she did not run as a three-year-old.

A little more should be said of animals who come into this pedigree. L'Abbesse de Jouarre, the daughter of Trappist and Festive, brings another classic element into the family. It is somewhat strange that two animals of the highest class should have made their first appearance, and that in the same race, at Croydon, where class was seldom represented. For the Two-Year-Old Plate, however, the subsequent Oaks winner and Amphion first came out, the colt favourite at 2 to I, the filly backed at 5 to 2 . He won, but she did not perform in a manner to suggest that she was the animal she proved to be. But she soon came to the front, winning the May Plate at headquarters, also the Newmarket Two-Year-Old Plate, and what was hoped of her is shown by the fact of her having been sent to Ascot for the Fern Hill Stakes, where Hazelhatch beat her by three parts of a length. She also won the West Riding Champagne Trial 
Stakes at Pontefract. As a three-year-old the Oaks was her first and last victory. She had a neck the better of the finish, starting at 20 to I, with the favourite Mr. Vyner's Menthe 9 to 4. She ran well for the Hunt Cup, third to Whitelegs and the Cambridgeshire winner Veracity; this being among the comparatively few races in which one of Captain Machell's good things did not come near to anticipation, Danbydale a 5 to 2 favourite being badly beaten. She remained in training for a third season and part of a fourth. As a four-year-old she started by taking the EI 000 Princess of Wales's Plate at Sandown. In the Manchester Cup weighted with 8 st. $6 \mathrm{lb}$. she carried $8 \mathrm{st} .8 \mathrm{lb}$. in order that Tom Cannon might ride, and earned the $£ 2202$ by three parts of a length. For the Gold Vase at Ascot she was second to Sir Mortimer Singer's Tyrant, a horse for whom a remunerative series of coups had been successfully projected; and she beat Antibes in a match at the Newmarket First July. Father Confessor, who had been second to her at Manchester, beat her in the Liverpool Summer Cup, the form coming out with much accuracy; at Manchester she gave $5 \mathrm{lb}$, at Liverpool just failed to give 7 lb., and proof of her exceptional speed was afforded when she took the Portland Plate with 9 st. As a five-year-old after one failure she won the Hardwicke Stakes at Ascot, her last appearance. Trappist, her sire, a son of Hermit and Bunch, was one of a little $\mathrm{Y}$ 
company of exceptionally speedy horses, Lowlander and Ecossais among them, who were constantly running with varying results. Trappist won the Stewards' Cup as a three-year-old in I875, carrying 7 st. 7 lb.

Sterling, by Hopeful out of a mare by Flatcatcher, was a really good horse, and if he did not run in the classics showed himself up to classic form by beating King of the Forest in a match, King of the Forest having dead-heated with Albert Victor for second place in the Derby behind Favonius. After a long absence Sterling returned to win the Liverpool Autumn Cup of 1873 with the burden of 9 st. 4 lb. Galopin must also be mentioned. This son of Vedette and Flying Duchess was doubtless one of the best horses ever known. For several years it was my frequent custom to ride out on Newmarket Heath in the morning with the late John Dawson, who was perhaps better able to estimate Galopin than anybody else could be; and he was not prepared to admit that the horse's son St. Simon was his sire's superior. John Dawson would never express an opinion as to precisely how much Galopin was superior to Petrarch. I gathered from him that it was a question of very many pounds; and yet amongst other races Petrarch won the Two Thousand, the Gold Cup and the Leger.

Galopin came out for the Hyde Park Plate at Epsom, when a colt named Cachmere beat him a head. 
Apparently he ought not to have done so. An objection followed. The Stewards who investigated it were Mr. Caledon Alexander acting for Lord Falmouth, Mr. W. S. Stirling Crawfurd for the present Lord Chaplin, and Admiral Rous. "We are of opinion that Constable on Cachmere unintentionally cannoned against Morris, riding Galopin, which prevented the latter from winning. Galopin is therefore the winner of the Hyde Park Plate, and Cachmere is not entitled to a place." Such was their verdict. At Ascot Galopin won the Fern Hill Stakes-there was a Quantock in this race, by the way, a colt by King of Trumps-and also the New Stakes. In the Middle Park Plate Plebeian won by a head from Per Se, Galopin another head behind, after a finish which led to another objection, Galopin's friends protesting that he had been bumped out of it; but the Stewards declined to interfere. He won a couple of Sweepstakes and was allowed to walk over at the Houghton Meeting. His three-year-old career was started by a match with Stray Shot, the dam of Shotover, winner of the Derby in I882, which Galopin won by eight lengths, and starting favourite for the Derby at 2 to I he had not the least difficulty in disposing of Claremont, Lord Falmouth's then unnamed son of Macaroni and Repentance, ridden by Archer, following him home. After this it seemed a little remarkable to find him again contesting the Fern Hill. This he won, as 


\section{A GREAT YEAR}

he did a match with Lowlander over the Rowley Mile. In the autumn he beat the Leger winner Craig Millar and Balfe for the Newmarket Derby, his last appearance.

Such are the animals from whom Grand Parade descends. 



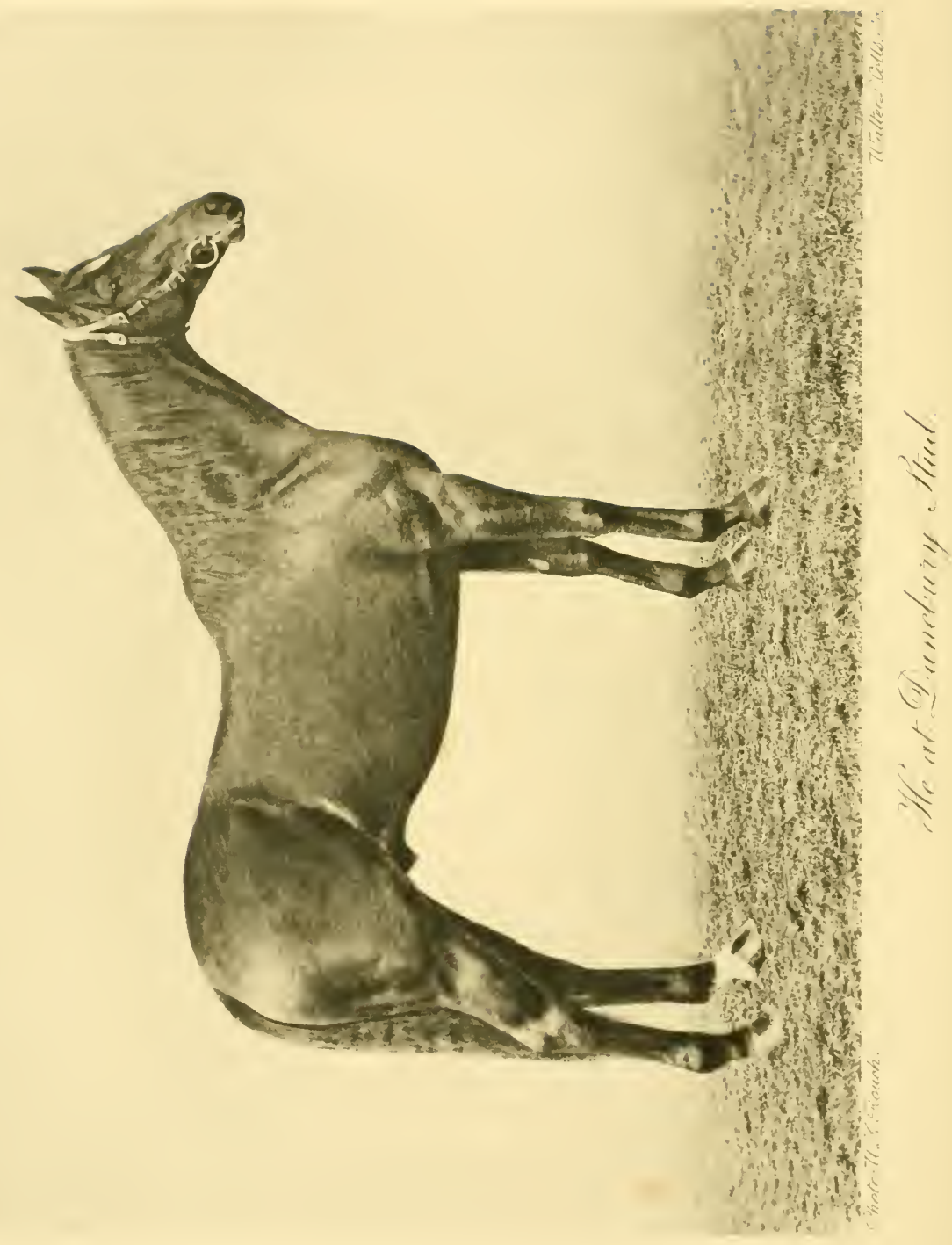




\section{CHAPTER V}

HE, SKY-ROCKET, AND TRECLARE

\section{HE}

Among the good horses Lord Glanely has owned, $\mathrm{He}$, the son of Santoi and She, ranks high, and here we obtain a strain of remarkably stout blood, for Santoi was by Queen's Birthday-Merry Wife, Queen's Birthday by Hagioscope-Matilda, who goes back to King Tom. The blood in question may not be absolutely the bluest, for Queen's Birthday came short of classic form and the sturdy Hagioscope would have been rated as a superior handicap horse, but on the dam's side equine aristocracy is powerfully represented, for She is a daughter of Cyllene, her dam Witty Girl by St. Simon-Bettywise by Wisdom, the last named another horse resembling Tredennis in the circumstance that his reputation was made at the stud. Merry Wife again was by Merry Hampton, a Derby winner, out of a mare by Pero Gomez, winner of the Leger.

My old friend George Edwardes was somewhat 
inclined to regard his geese as swans, and I remember discounting his estimate of Santoi, who, however, presently gave abundant evidence that the estimate was not by any means too exalted. For the Salisbury Stakes of 1899 Santoi was not expected. A boy named Pickles had the mount and as the phrase runs "there was no money for him." He was merely indeed being introduced to the racecourse, nor was his chance at his second attempt, for a Maiden Plate at Redcar, regarded as other than remote. He came on. T. Loates rode him in the Crowborough Nursery at Lingfield, which he won from a 6 to 4 favourite in Minerette, and for the rest of the season he remained busy, missing the Orleans Nursery at Sandown, but carrying home his 8 st. I I lb. in the Grange Nursery at Gatwick. In two other Nurseries he was overweighted. Of the nine races he ran as a three-yearold he won four in good company, if not so good as that which he encountered afterwards. For the Twickenham Handicap at Sandown he just got home with nothing to spare, and Sloan on an even money favourite Joubert beat him for the opening race at the Epsom Summer Meeting. Lord Derby's Crestfallen, so often quoted as an example of a perfect name, by Ocean Wave-Dolores, won the Ascot High Weight Handicap, Santoi second, but George Edwardes secured the Brighton Cup from the subsequent City and Suburban winner First Principal, as also the 
Lewes Handicap, then failed in the Scarbrough Stakes, before carrying off the now. extinct-unfortunately so-Free Handicap for Three-Year-Olds at the Houghton, and after a miss in the Derby Cup, was beaten only a short head for the Manchester November Handicap.

Although after winning his first three races as a four-year-old Santoi was beaten twice as often, these defeats tended much to strengthen his position. $\mathrm{He}$ led off by securing the Kempton Park Jubilee, giving Caiman-one of the two horses who had beaten Flying Fox-4 lb. and winning by a neck. He won the $£$ rooo Great Whitsuntide Handicap at Hurst Park from Rambling Katie, a filly of his own age, giving her $40 \mathrm{lb}$., and achieved perhaps the highest honour the Turf affords by carrying off the Gold Cup. His victory was, moreover, anticipated, for he started favourite at II to Io and beat Kilmarnock II., who as the market showed was expected to be a good second, so much being thought of the latter that he started at 6 to 4 . This meant for Santoi 9 st. $7 \mathrm{lb}$. in the Derby Cup which was his next objective, and proved too much, as did 9 st. Iolb. in the Great Yorkshire Handicap. The colt tried his luck in the Cesarewitch, but the task proved beyond him. His 9 st. $7 \mathrm{lb}$. meant giving $44 \mathrm{lb}$. to the useful Balsarroch, $23 \mathrm{lb}$. to the four-year-old Black Sand, who was to win the race next season, $4 \mathrm{I} \mathrm{lb}$. to Rambling Katie, and 
to make impossible concessions to others. Balsarroch won by half a length from Black Sand, Rambling Katie beaten two lengths for second place, and Halsey on Santoi did not persevere.

For the Kempton Park Stakes an extraordinarily good field went to the post. The favourite was Volodyovski, backed at 7 to 4 , winner of the Derby ; Santoi, winner of the Gold Cup, followed at 4 to I ; Doricles, winner of the Leger, 9 to 2; Epsom Lad, who had won the Eclipse Stakes and was to win the Princess of Wales' Stakes next season, 5 to I ; William the Third, who was to win the Gold Cup next year, and had run second for the Derby beaten three parts of a length after winning the Newmarket Stakes and other good races, I 3 to 2; and Merry Gal, another winner of the Princess of Wales's Stakes, 20 to $\mathrm{I}$. Epsom Lad won from Santoi by three-quarters of a length, but Mr. George Edwardes' colt was giving him $3 \mathrm{lb}$. The Derby winner was third, running Santoi at weight for age.

It may perhaps be considered a pity that he was trained as a five-year-old, though he won a race rather clumsily called the Coronation Commemoration Stakes, £I 790, giving Volodyovski a pound and beating him half a length. But Santoi failed in the Jubilee, the Coronation Cup, and in the Gold Cup was third to William the Third and Osboch; Volodyovski and the Oaks winner, Cap and Bells II., among the eight 
behind him. He left off with defeats in the Doncaster Cup and the Duke of York's Stakes.

Santoi's sire Queen's Birthday began in somewhat humble fashion. The son of Hagioscope ran nowhere for the Zetland Stakes at the York Spring Meeting, did no better at Redcar, won a Nursery worth $£$ I 50 with the best of the weights at Musselburgh and was nowhere again in a Nursery at Derby. But as a three-year-old he only failed once, and that in the Leger, a remarkable record, as he was out seven times. At Leicester he took the Northern Welter; did not reappear till August, when he won the Kirkleatham Biennial at Redcar, and next day the Great Northern Breeders' Foal Stakes. Just a week later at Stockton he beat a couple of opponents for the Great Yorkshire Stakes, and apparently he was fancied for Memoir's Leger, his starting price being as little as 7 to $\mathrm{I}$. His backers lost their money, even if they "saved "for a place, as the Duke of Portland's filly was followed home by Blue Green, Gonsalvo and Sainfoin. At the Houghton Meeting he won a handicap of 5 sov. each with a 1000 sov. added. He was best as a four-yearold, well backed for the Doncaster Spring Handicap in spite of his top weight 9 st., and then came the performance on which his reputation chiefly restshe was only beaten half a length for the Gold Cup by Morion, a really good horse who had won the Hunt Cup as a three-year-old with 7 st. 9 lb. the previous 
season. Queen's Birthday went on to win the Northumberland Plate, carrying 9 st., as also the Doncaster Cup.

It is assumed that Prince Batthyany had no idea of the treasure he possessed in St. Simon. He must have thought highly of the colt, however, for though not many two-year-old engagements were made for him he was entered in the New Stakes and the Middle Park Plate. His owner died suddenly at Newmarket in the course of a meeting, the consequence being that the colt was put up for sale. There is a story of a dressing being applied to one of his legs just before he was brought into the ring in order to convey the impression that there was something wrong; but how true this may be I am not aware. If memory serves the Duke of Portland secured him for I 500 guineas, and it was to the end of John Dawson's life a source of vexatious regret that he had not made an effort to obtain possession. The colt's engagements being voided, new occupation had to be found for him, and the Halnaker Stakes at Goodwood provided an opportunity. Starting at even money with Archer in the saddle he won by half a dozen lengths, and next afternoon beat a solitary opponent for a Maiden Stakes. His lack of engagements led to his appearance in Nurseries. With 8 st. I 2 lb., ridden by Archer - a colt of that name belonging to Robert Peck was favourite at 7 to 4 , St. Simon at I I to 4 -he 178 
cantered home for the Devonshire Nursery; with 9 st., backed at I I to 8, he won the then seven furlong Prince of Wales' Nursery at Doncaster by eight lengths, and then beat the Duke of Westminster's Duke of Richmond, a colt very highly esteemed, in a match over the Bretby Stakes course.

Those who are not acquainted with the history of St. Simon may perhaps be surprised to learn that as a three-year-old he was only out on four occasions and only ran three races, having been allowed to walk over for the Epsom Gold Cup, a race which now figures in the programme as the Coronation Cup. It was the style in which he won the Ascot Cup that created so great an impression. St. Simon was opposed by $M$. Lefevre's Tristan, the Duke of Portland's Iambic, a very bad horse started to make a pace for his stable companion, the Duke of Beaufort's Faugh a Ballagh, and the Duke of Hamilton's Friday. None of these could make St. Simon gallop, and he won by twenty lengths. It cannot have been recognised how good he was, for backers were allowed to lay 75 to 40 on him. He really had nothing to do in the Gold Cup at Newcastle and practically nothing in the Goodwood Cup. Here the betting was roo to 7 on St. Simon, 20 to I against Friday, 33 to I against Ossian. The last named had won the Leger of the previous season, but I believe was not sound in his wind as a four-year-old. After this St. Simon disappeared 
from the Turf to earn his brilliant reputation at the stud.

\section{SKY-ROCKET}

Sky-rocket won a great trial as a two-year-old and had he kept right would surely have been recognised unmistakably for what he was, in the very first class as a racehorse. His breeding is so superb that it would have been a sad mistake not to afford him his chance as a sire. Sky-rocket was a son of Sunstar and Maid of the Mist, thus obtaining the blood of the beautiful Amphion together with that of the great mare Sceptre. $\mathrm{He}$ is half brother to the Oaks winner, Sunny Jane, and to the Two Thousand winner, Craig-an-Eran. Unhappily the career of Sunstar was cut short at an early period. $\mathrm{He}$ broke down in the Derby, never being able to run again; but the son of Sundridge and Doris had accomplished enough when carrying Mr. J. B. Joel's black jacket, red cap, firmly to establish his fame, and his success at the stud has been extraordinary.

Like so many famous horses Sunstar first came out in the New Stakes at Ascot, the date rgro. He was considered to have a good 5 to I chance, though there were two better favourites, Seaforth at 5 to 2 and Feramoz at 3 to $\mathrm{I}$, and the former took the race from a French colt, M. E. de St. Alary's Nérestan. At the Newmarket First July Meeting Sunstar ran for 180 


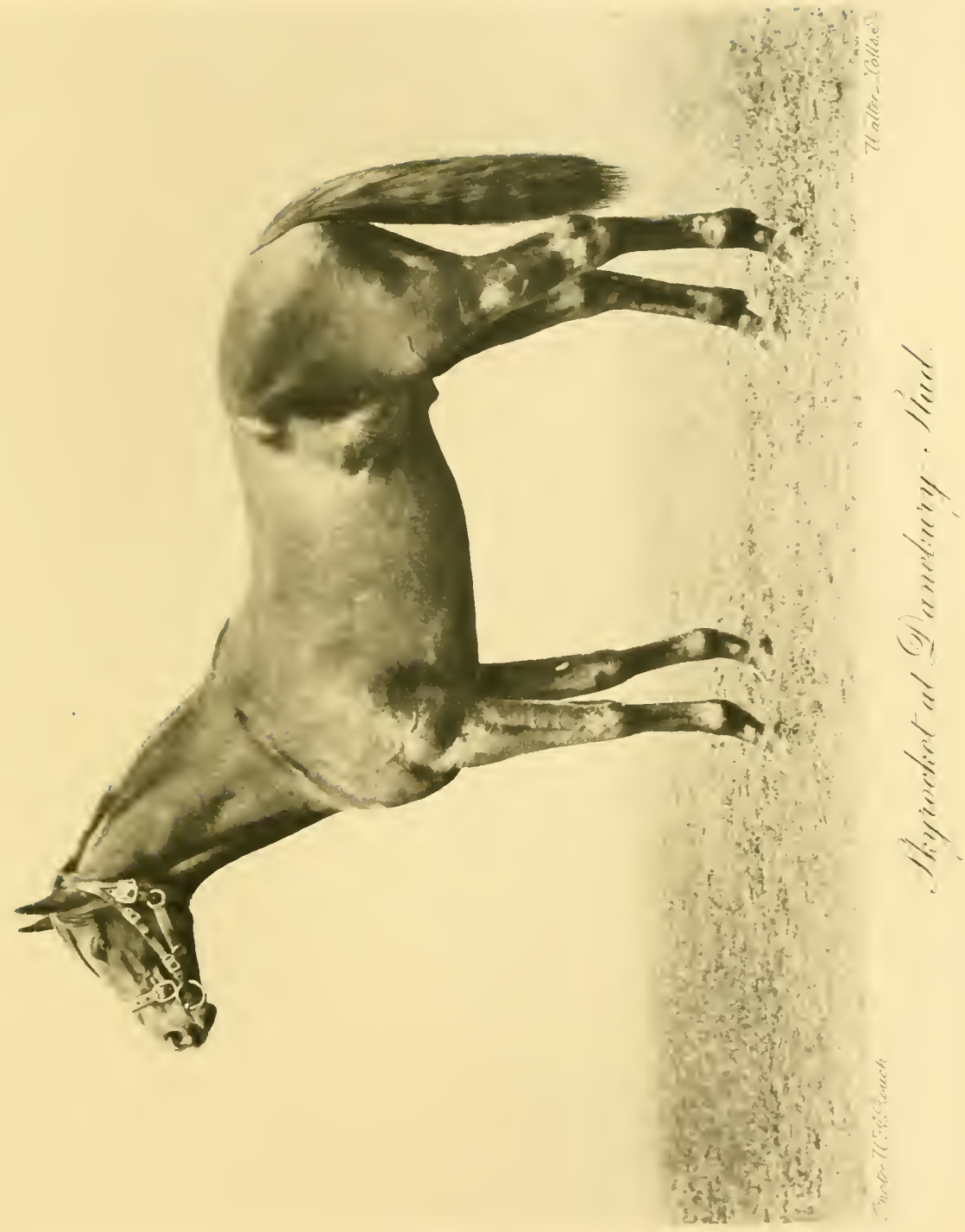



the Exeter Stakes, one of the earliest six furlong races of the season. It hardly seemed probable at the time that the colt would stay, and a multitude of two-yearolds who win easily at five furlongs find the additional furlong too much for them. Sunstar, however, lasted well and secured the race by a neck from Major Eustace Loder's Canvas-back, Mr. H. P. Whitney's Borrow unplaced. This American colt was supposed to be the chief danger to Sunstar, and with good cause, his merit being so considerable that he won the Middle Park Plate from Seaforth and Pietri. I believe also since his repatriation he has gained a speed record in the United States. Sunstar's two-year-old career, it will be seen, was an example of what at roulette are called intermittences, a defeat being always followed by a success. In the Lavant Stakes at Goodwood he was beaten by Mr. S. B. Joel's St. Nat, an anticipated result. Then he won the International Two-Year-Old Plate at Kempton, as was also anticipated. Again he was beaten, a short head and two lengths by Pietri and Wrinkler for the Champagne Stakes at Doncaster, and then he earned brackets by dead-heating for the Hopeful Stakes at the Newmarket First October with Borrow. Sunstar gave $3 \mathrm{lb}$., which was merely weight for sex, as Borrow is a gelding.

From two-year-old to three years old Sunstar made excellent progress, and in his second season was never beaten. He reappeared in the Two Thousand 
Guineas, for which Pietri was in chief demand at 5 to 2. Sunstar, who stood at just twice the odds, won by a couple of lengths from Lord Derby's Stedfast, who did not get off well, though ridden by Wootton, who was seldom behind when the flag had fallen; Mr. Joel's second string Lycaon third. Seaforth was by now out of form and 100 to 7 could have been had about him. Nothing seemed in the least likely to interfere with Sunstar in the Newmarket Stakes. What was thought of the race indeed the betting demonstrated- I 00 to 7 on Sunstar, I00 to 8 against Royal Eagle, 20 to I Beaurepare and Bridge of Allan. Sunstar won by two lengths. For the Derby a field of 26 went to the post, Sunstar favourite at I 3 to 8 , Pietri coming next at 7 to $I$, and for the third time the favourite gained a two lengths' victory from Stedfast, who again this time got away slowly. Sunstar finished on three legs, and was forthwith relegated to the stud. It is to be regretted that the colt could not run for the Leger and by winning it add further proof that the son of a non-stayer is not necessarily unable to stay himself.

Sundridge, by Amphion out of Sierra, sire of Sunstar, was emphatically a short runner. He could only be produced once as a two-year-old, and that as late in the season as the Newmarket Houghton Meeting, when he contested an optional selling race, not however, luckily for Sir Samuel Scott, his owner, entered 
to be sold. The winner was bought in for 510 guineas. Next season Sundridge started off well if unambitiously, taking the Heath High-weight Handicap at the Newmarket First Spring, Rous course, and he followed on by a success, the Earl of Chester's Welter Handicap, winning easily by three lengths in the hands of Morny Cannon, burdened with 9 st. I lb., several older horses having much less weight. For the Royal Plate at Epsom Summer he was second to that speedy horse Master Willie, who came very near to making a record down this hill, having done the five furlongs in 56 and $2 / 5^{\text {ths }}$ seconds; and there were other notable sprinters in the race, Dieudonné, Bridge, Sonatura, the Lincolnshire Handicap winner Little Eva, and La Lune, another who used to come at a great pace down the Epsom Hill.

He was fully equal to the occasion, however, in the July Stakes at Newmarket, and very nearly so in the Portland Plate at Doncaster, for here in receipt of only $2 \mathrm{lb}$. from Dieudonné, then a six-year-old, the young one failed by no more than three parts of a length. There is always a good field for the Portland Plate and here were the Stewards' Cup winner O'Donovan Rossa, Orchid, Elizabeth M., Leisure Hour and Mazeppa, who had won this Plate two years previously, also La Lune, Water Lily, who started favourite, and Northern Farmer. Sundridge was not fancied, at any rate by the public, for the Prince 183 
Edward Handicap at Manchester, it being rightly suspected that he was not in the least likely to stay the mile and a quarter; consequently 100 to 8 was on offer, a result of his performance being that he was never again started for a race over more than the six furlongs which was his proper distance, or at least it should rather be said his limit, as he probably preferred five. In the $\oint_{1000}$ Duke of Richmond Plate at Kempton he had too much to carry, as he had againwithin a pound of 9 st.-in the Croxteth Plate at Liverpool, but he wound up his three-year-old career by easily taking the Chatsworth Plate at Derby.

There was a certain similarity between the record of Sundridge as a three-year-old and as a four-year-old. In both cases he began and ended with a win, and was beaten because the handicappers were at times somewhat too severe. He led off with the Teddington Plate at Kempton, found $9 \mathrm{st} .5 \mathrm{lb}$. too much for him in the Royal Stakes at Exsom won by Sir James Miller's useful Cossack with just a stone less weight; took the July Cup, which has seldom fallen to other than a horse of mark; but 9 st. $4 \mathrm{lb}$. was more than he could carry to the front in the Stewards' Cup-at Goodwood need hardly be added, for that is the Stewards' Cup-and with Io st. was beaten into third place by Orchid, 9 st. 2 lb., for the Marine Plate at Brighton. A couple of seconds to good horses, Chacornac and Lord Bobs, preceded an easy victory 
in the Chatsworth Plate, which he had won the previous year.

As a five-year-old, the horse having been sold by Sir Samuel to Mr. J. B. Joel, he was at his best, missing only in two of his seven attempts. Again he led off with the Teddington Plate, won the Royal Stakes from the Oaks winner, Mr. Foxhall Keene's Cap and Bells II., the mare in receipt of I9 lb.; won the King's Stand Plate at Ascot from Newsboy, the July Cup for the second time, 25 to I on him, for all but one poor opponent were frightened away. With the crushing burden of $9 \mathrm{st}$. I $\circ \mathrm{lb}$. it is not surprising that he should have been beaten for the Stewards' Cup, though his reputation was so high that he found backers at 10 to I. At Lewes he started favourite for and won the de Warrenne Handicap, which at the time usually brought out several Stewards' Cup horses; and then he disappointed his admirers by failure in a match with Le Blizon, though there was the sound excuse for him that he was trying to give that speedy horse only $2 \mathrm{lb}$. short of 2 st. Sundridge ran as a six-year-old and sustained his reputation. The Egmont Plate at Epsom he lost by only a short head, endeavouring to give the winner, the late Mr. George Edwardes's Nutwith, exactly 4 st.! For the second time he won the King's Stand Plate and for the third time the July Cup. Against him in the last named I 3 to 8 was laid, Cossack starting at 6 to 4 on. His third trial for $2 \mathrm{~A}$ 
the Stewards' Cup with 9 st. I I lb. was another miss, but for the second time he won the de Warrenne, by a neck from Fariman in receipt of $\mathrm{I} 7 \mathrm{lb}$., lost the Portland Plate by a head to Santry in receipt of $22 \mathrm{lb}$., won the Snailwell Stakes, the Kennett Plate, but unfortunately left off with a failure, beaten in the Challenge Stakes by that exceptionally good horse Delaunay, who only lost one of the eleven races he ran that year, that having been the Cambridgeshire taken by Hackler's Pride.

Elsewhere in this book mention is made of Amphion, the son of Speculum or Rosebery-the latter may be credited with the sireship-and Suicide, a horse it is a pleasure to recall, for I do not recollect a more beautiful one than this golden chestnut, full of quality. It is remarkable that he together with the subsequent Oaks winner, L'Abbesse de Jouarre, the joint property of Lords Dunraven and Randolph Churchill, should have come out for the Croydon Spring Two-Year-Old Plate of I888; for at Croydon good flat-race horses were rare. Ridden by Watts, General Byrne's colt won easily by three lengths, the filly unplaced. Trained as he was at Stockbridge Amphion was naturally engaged at the meeting there and took the Champagne Stakes-ridden by Tom Cannon, who was to be associated with a number of his triumphsalso the Great Kingston Two-Year-Old race at Sandown from Mr. Redfern's useful horse Yard Arm. Three 
defeats balanced the three successes. He failed with 9 st. in the Kempton Park Champion Nursery, again in the Orleans Nursery at Sandown, nor could he manage with $2 \mathrm{lb}$. less weight in the Chesterfield Nursery at Derby. As a three-year-old he was soon ready, won comfortably the Doveridge Handicap at Derby in April, and just a month later the third celebration of the Kempton Park Jubilee took place. Three horses were chiefly fancied and started at 5 to I or II to 2, the Duke of Westminster's Orbit, Tom Cannon's True Blue II. and Mr. Leybourne's Goldseeker.

The last named may be described as the victim of a misadventure. Probably it is safe to assume that he is the only horse whose victory in the City and Suburban has ever been a source of grievous displeasure to his friends. Goldseeker had been heavily backed for the Jubilee, but it was thought as well to let him take part in the Epsom Handicap on the supposition that a race would do him good, it never being for a moment imagined it was in the least likely that backward as he was he could carry his 8 st. successfully. No orders were given to his jockey, Tom Cannon, junior; and to the consternation of those connected with the colt he came in first! The trouble was that this involved a $\mathrm{I}_{4} \mathrm{lb}$. penalty at Kempton, in spite of which, as just remarked, he started practically favourite, the extra doubtless stopping him and enabling Amphion 
to carry home his $7 \mathrm{st}$. I lb. This included a $7 \mathrm{lb}$. penalty for his Derby race, and he was supposed not to have much chance, starting at 100 to 8 , as did Lord Cholmondeley's Screech Owl, the runner up.

Amphion went to Ascot and won the Fern Hill Stakes. As General Byrne, his owner, was about to mount the steps of the Iron Stand he was stopped by an acquaintance who asked if his colt could win, to which he dryly replied, "That is just what I am going upstairs to ascertain!" There was some trouble after this race, not however involving Amphion. Hammond, the owner of St. Gatien and Florence, together with his jockey Rickaby, were called before the Stewards to explain the running of a filly called Paloma, who had been snatched up very sharply. The jockey was acquitted of evil intention, and Hammond cautioned against "tying down his jockey with orders not to be second or third." On the Thursday Amphion won the Biennial. At Goodwood there was a great race for the Stewards' Cup, in which the colt was just beaten a neck by a very speedy animal called Dog Rose with I 5 lb. less weight. He was then second for the Free Handicap for Three-YearOlds, a now extinct race, to Ormuz in receipt of $25 \mathrm{lb}$.

In April over a mile a three-year-old receives from a four-year-old $9 \mathrm{lb}$. In the Esher Stakes at Sandown the now four-year-old Amphion had to give the threeyear-old winner $33 \mathrm{lb}$, and as that winner was Sainfoin, 
who was soon after to win the Derby, the result can hardly create surprise. Amphion's Jubilee weight had gone up $34 \mathrm{lb}$., to $9 \mathrm{st}$. $7 \mathrm{lb}$., so that he was giving $48 \mathrm{lb}$. to The Imp, who won, and then came the chestnut's turn. He carried off a biennial at Ascot on the Wednesday, and on Friday in the Hardwicke Stakes met Sainfoin, with his Derby honours thick upon him naturally favourite, Surefoot, the winner of the Two Thousand, backed at 2 to I; and Amphion beat them both, having a length the better of Sainfoin, who was five lengths in front of Surefoot. That was good for the colt's reputation, and the next event good for his owner's banking account; for this was the Lancashire Plate, which that year produced for the winner $\$ 9096$ I $5 \mathrm{~s}$. Amphion was an I I to 8 favourite, Memoir I I to 4 , Orme 7 to I, and Io to I bar the three. In the hands of Tom Cannon Amphion won by a length and a half from Martagon, Lord Rosebery's two-year-old Corstorphine third. He beat Memoir again by three lengths for the Champion Stakes, and at the Houghton Meeting took part in "A Plate of II "Oo sov. Run over two miles." The Hardwicke, it is perhaps unnecessary to remark, is a mile and a half, and that as just described was within Amphion's compass; two miles was too far for him against such a notable stayer as Prince Soltykoff's Cesarewitch winner Sheen, and Amphion was beaten three lengths. 
An incident which for some reason dwells in my mind is Tom Cannon cantering to the post on Amphion for the March Stakes at the Newmarket First Spring Meeting. It struck me as what is called the poetry of motion. He won by a length and a half, the jockey beating his son Morny on Mark Price. One naturally looked for Amphion at Ascot. This season as a five-year-old he ran for the Rous Memorial, to win by two lengths from the Chevalier Ginistrelli's famous Signorina. That was nearly the end. $\mathrm{He}$ walked over for the Stockbridge Cup, and came out for the last time in the $£ 6000$ Leicestershire Royal Stakes. The order of the finish was Rusticus, 7 st. ; Victoricus, 7 st. 7 lb.; Enniskillen, 6 st. 4 lb. ; Amphion, ro st. $7 \mathrm{lb}$. Those connected with the second were desperately anxious to secure the race. After an objection for bumping and boring had been overruled, another was formulated on the ground that Rusticus, described as a black, was in reality a chestnut -or it may have been the other way about. This was also overruled. It was a pity that Amphion should have been beaten on the occasion of his farewell, but the weight was an impossible one.

Brief mention must be made of Rosebery. He was in the hands of clever people who meditated a coup, which they successfully brought off. It was believed that the colt would be good enough to win the Cesarewitch with the $7 \mathrm{st} .5 \mathrm{lb}$. allotted to him and to follow 190 
on by carrying his penalty in the Cambridgeshire. For the second race he had been weighted with 7 st. $5 \mathrm{lb}$., and the extra stone did not stop him. See Saw, his sire, is the horse of whose Cambridgeshire victory a story is told. Somebody who believed he would receive a very handsome legacy from an aunt found to his chagrin that the extent of it was $\oint_{1} \mathrm{O}$, and in his disappointment he determined to throw it away by backing the longest priced horse in the approaching Cambridgeshire. See Saw was his choice, and the $£$ Ioo grew to $£ 3300$, for about the colt he was able to book odds at the rate of 100 to 3 .

Reverting to Sunstar's dam it must be admitted that Doris, the daughter of Loved One and Lauretta, appeared as unlikely to produce a Derby winner as well-nigh any mare that could have been named. As regards her doings when in training she ran nine times. I must have seen her on nearly every occasion, that is to say watched the races in which she took part, without, however, paying any attention to the filly, and I have no recollection of her. She came out in 1900 for the Worksop Plate at Leicester and won it by a neck, the value of the race being exactly $£$ Ioo. After four misses she won the Juvenile Selling Plate, worth fr 95, at Epsom, by a head, the race which immediately preceded Diamond Jubilee's Derby, and was bought in for 300 guineas. In three subsequent selling races she was beaten, and I believe that Mr. S. B. Joel gave 
her to his brother, for whom she did such wonderful service in the paddocks. She never ran as a threeyear-old, probably because it was not thought worth while to keep her in training. I am told that she was mean in appearance, in fact she would have been considered by many breeders out of place amongst her new owner's choice selection of mares. And as one more example of the glorious uncertainty of the Turf she did vastly better than any of the others. Truly one never knows!

Loved One, the property of Mr. Manton, as the Dowager Duchess of Montrose chose to be called, was always there or thereabouts as a two-year-old. Coming slowly to hand he waited till the Newmarket First October Meeting (I885), when he ran Prince Soltykoff's Mephisto, on whom 3 to I was laid, to a length for the Boscawen Stakes, and in the Clearwell he finished third, beaten just a length by the Duke of Portland's subsequent Oaks winner Miss Jummy, the favourite, Lord Bradford's Martinet, intervening. Loved One took the Cheveley Stakes from a French colt, M. Lupin's Phœbus, and then showed the extent to which he had come on by beating Mephisto three lengths for the Home Bred Foal Post Stakes at the Houghton Meeting. As a three-year-old he led off by cantering away with the Wokingham, the verdict being six lengths. That was his last success, for he was beaten in the Stewards' Handicap by Crafton and 



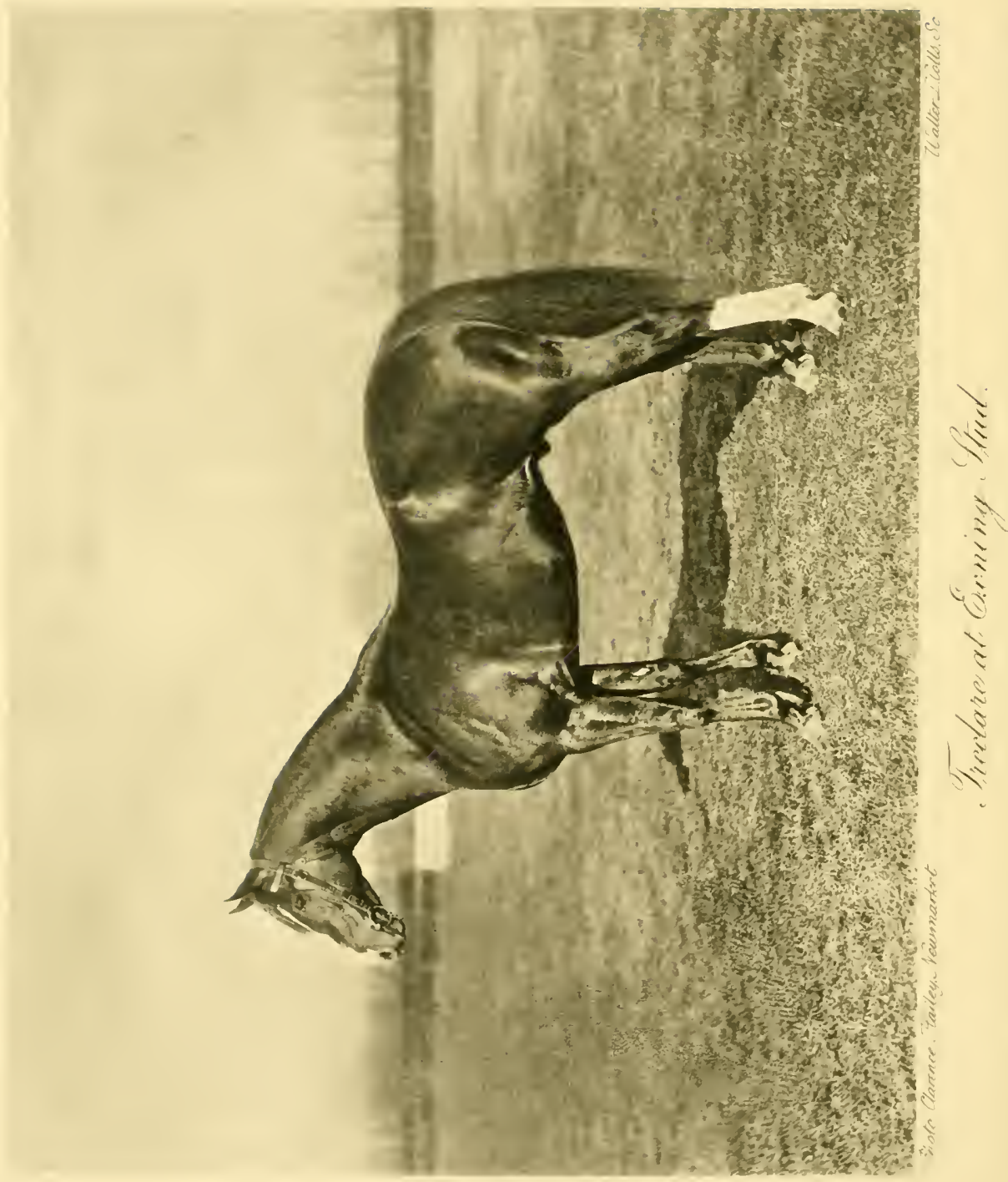


in the Chesterfield Cup by Saraband, being, however, set to receive only $5 \mathrm{lb}$. from that good horse. Others beat Loved One it must be understood, as he was unplaced, and he failed again in the Select Handicap at headquarters.

\section{TRECLARE}

Lord Glanely's Treclare is a son of Tredennis and Clare, and the history of his sire as a racehorse is very soon told. He did nothing. As a two-year-old he never ran, as a three he carried Captain Machell's white, blue cap in the Tudor Plate at Sandown, ridden by a little known jockey and made no show, the absence of his name from the market quotations suggesting that this was extremely probable. He did not come out again until the Newmarket Second October, when he was one of the ruck in a Visitors' Handicap, without a price. As a four-year-old he went to the post for a Welter Handicap at the First Spring and did no better than he had done before. It seems probable that the name of Tredennis was never written in a betting book. But as a good-looking son of Kendal and St. Marguerite it was, as the event proved, very wisely determined to give him a chance at the stud, and the fact that having started at a fee of five guineas he gradually ascended to a fee of 100 guineas is the amplest justification. One of his sons was that good horse Bachelor's Double, another the extraordinarily speedy Hornet's Beauty. 
If Ugly Duckling were nearly as good as many backers seemed to suppose, his name should not be omitted.

For information about Kendal we may again turn to John Porter's book. Chapman, the stud groom, is quoted as having said, "Did the Duke at that time regard Orme as a wonder? No, I should say not. Like a good many others who came to the stud that year, the Duke preferred Kendal and Whitefriar." Porter relates that on the 7 th of October, I 885 , a trial took place in which Kendal, carrying 8 st. 7 lb., beat Ormonde, 8 st. 8 lb., by a length. The horse whom the old trainer describes as "the ever-reliable Whipper-in," and Whitefriar, a two-year-old by Hermit, who had not yet raced, were behind. Whipper-in, then a six-yearold, was trying to give only $12 \mathrm{lb}$., and was beaten another length. The weight Whitefriar carried is not stated. Kendal, by Bend Or out of Windermere, is said to have been " a leggy colt, standing as a two-yearold about I 5.3, fairly well proportioned, but somewhat light of bone and heavy about the neck," and as regards the gallop there is the excuse that Ormonde was at the time decidedly backward.

Had Kendal's lot been cast in an ordinary year he would surely have taken high rank, if not the highest, but coming in the year he did it must be confessed he was at the severest disadvantage. Nevertheless as a two-year-old he won eight of the ten races for which he started. He was first produced at Chester and with 
odds of 5 to 4 on him, ridden by Archer, won the Mostyn Two-Year-Old Plate. Saraband beat him a length-and gave him $7 \mathrm{lb}$.-in the New Stakes, and then without a break Kendal won the Stockbridge Post Sweepstakes from Mephisto and Volta, the July Stakes, Mephisto second, the Ham at Goodwood from Modwena, the Convivial Produce Stakes at York, and walked over for the Municipal Post Stakes, now extinct, at Doncaster. Odds were laid on him for the Rous Memorial at the Newmarket First October Meeting, but there he ran badly. The finish of his career may as well be related. The Duke of Westminster presented the colt to his trainer as some recognition of his skill in dealing with Ormonde, and Kendal was leased to the late Lord Wolverton, who was then forming a stud at Iwerne Minster, near Blandford in Dorsetshire, and wanted a stallion. The terms were three years at $f_{3} 300$ a year with the option of purchase for $£_{1} 200$. Kendal's fee was 25 guineas. Lord Wolverton died before the lease had run its course, Lady Wolverton asked if Porter would mind breaking the contract, which he willingly did, and sold the horse to the late Mr. John Gubbins for $\&_{3} 3000$. Kendal then went to the Knockany Stud at Limerick, where he became the sire of the Derby winner Galtee More and other good horses, which induced Major Platt to give I 8,000 guineas for him. Major Platt sold him to a breeder in the Argentine, where he was 
a great success, and he died there at the age of twentyfive in I908. It is a pity John Porter did not keep the horse-or so it seems, for with different mares he might have had different luck.

St. Marguerite, whose blood enriches Treclare, must by no means be omitted from the record, for this lovely chestnut daughter of Hermit and Devotion, so many of whose brothers and sisters made names for themselves, is among the most notable of matrons, for a variety of reasons, one being that, a classic winner herself, she was the dam of Roquebrune, dam of Rock Sand, sire of Tracery, in turn the sire of The Panther, Abbots Trace, Monarch and other good horses. There were fillies well beyond the average in $\mathrm{I} 88 \mathrm{I}$, when St. Marguerite ran for the Hurstbourne Stakes at Stockbridge, and ridden by George Fordham was third to Geheimniss with Tom Cannon in the saddle, the latter jockey having just sold his mount to Lord Stamford. The deal, it may be observed, was very speedily concluded. "What do you want for her, Tom?" was the question asked. The great jockey, afterwards to be master of Danebury, replied " 2000 guineas, my lord." "Is she worth it?" Lord Stamford inquired. "I think she is." "Then I'll have her."

The week after Stockbridge she was third for the July, or to speak by the book, she dead-heated for third place with Dutch Oven behind Kermesse and 196 
Marden, and two days later she won the Chesterfield: at this period there was only one meeting at Newmarket in July. A great race took place for the Richmond Stakes at Goodwood, Dutch Oven (Fred Archer), St. Marguerite (George Fordham), and Kermesse (Tom Cannon) apparently finishing in a line, but the Judge gave it to Dutch Oven by a short head, being unable to separate the other two. Dutch Oven beat her for the Rous Memorial on the Thursday. She walked over for the Municipal Post Stakes at Doncaster —as Kendal was to do - was beaten by Lord Falmouth's Little Sister for the Wentworth Post Produce Stakes two days afterwards, and once more was third to Kermesse, this time for the Middle Park Plate. Soon afterwards Kermesse split both her pasterns, though by the exercise of Joseph Cannon's skill as a stableman she became sound and after an absence of just a year won a couple more races.

For the Bretby Stakes St. Marguerite had only one opponent, whom she easily beat, and for the Criterion, which used to finish up the hill at the "Top of the Town," she once more came in third, this time to Bruce, who started favourite for next year's Derby. She wound up her season by an easy victory in the Home Bred Foal Post Stakes at the Houghton Meeting. It will have been seen that when St. Marguerite did not win she was much in the habit of running third. She did so in the Column Produce Stakes and then 
secured inclusion in the ranks of classic winners by beating Shotover-who had won the Two Thousand and was to win the Derby-for the One Thousand Guineas. For the Oaks St. Marguerite was second to Geheimniss, and then third once more for the Coronation Stakes. At Goodwood in the Lennox Stakes she failed by a head to give $9 \mathrm{lb}$. to the Duke of Hamilton's Actress, but next day won the Nassau. 



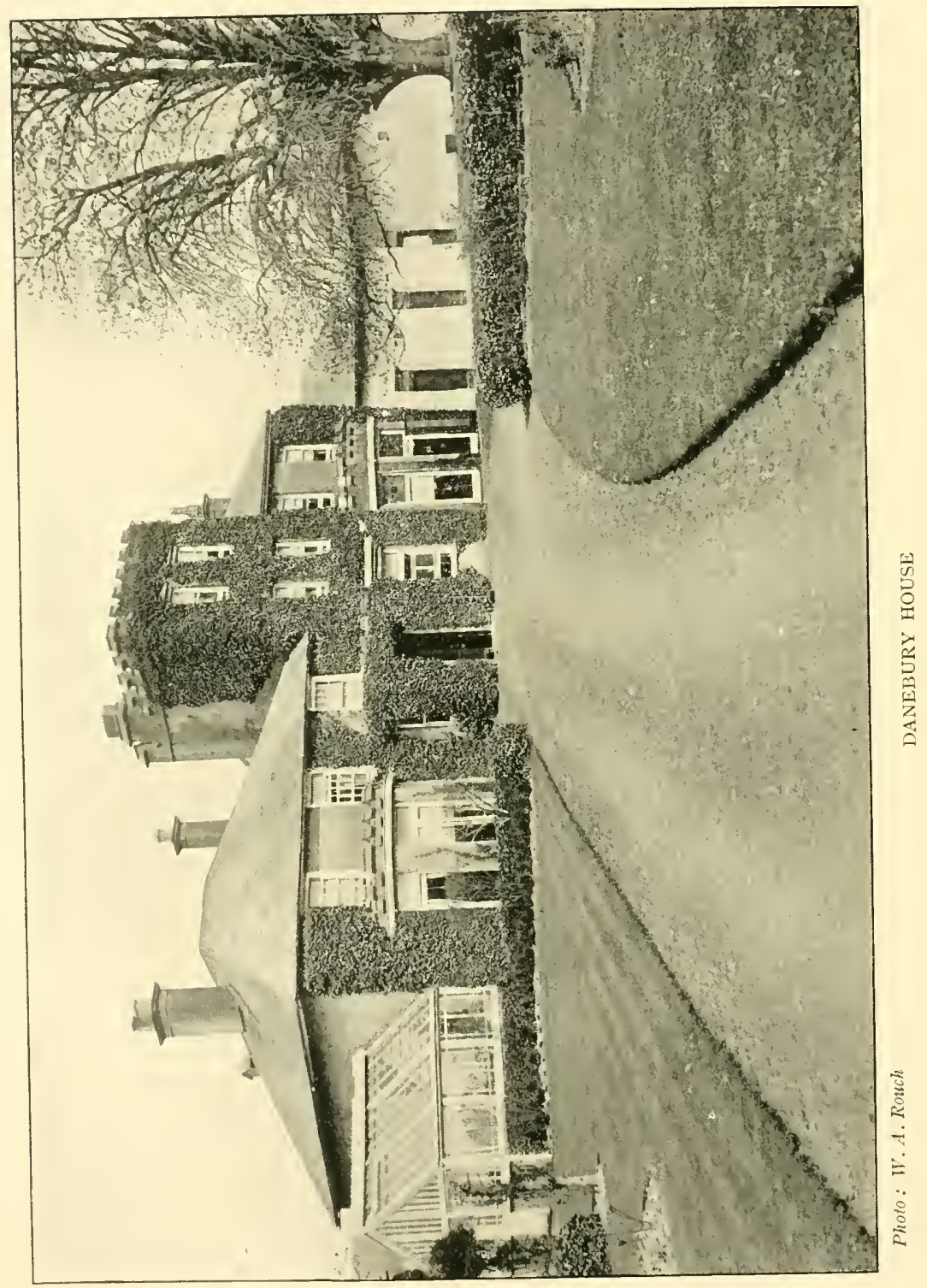




\section{CHAPTER VI}

DANEBURY AND THE MARES

By his purchase of the Danebury Estate Lord Glanely has become possessed of classic ground. What the Bibury Club and Stockbridge Meeting used to be was described by my old friend Lord Suffolk who might be best known as the literary Earl. Thus he writes in the "Racing" volume of the Badminton Library :

"The 'Calendar months' include no fixture more keenly anticipated and relished than those three summer days on the downs at Danebury. Stockbridge, to which the Bibury Club meeting was removed in $183 \mathrm{r}$, when local support failed at its birthplace on the Cotswolds, has seldom if ever attempted to provide the rich prizes which fire the ambition or the avarice of owners. The Hurstbourne, established in 1870 , at the suggestion of Lord Portsmouth, is now by far the most valuable of its stakes, the Stockbridge Cupa piece of plate value 300 sovereigns-coming next in order of importance, and the whole affair has always 
been in great measure dependent upon the patrons of the home stable and their friends.

"In the days when the Duke of Beaufort, Lord Anglesey, and Lord Hastings kept the Danebury boxes full, some big matches, or private sweepstakes resulting in matches, were occasionally made, notably those between Leonie and Athena, Mameluke and Innerdale, in 1867 , Tenedos and Wellington in I 868 ; while the races, big and little, usually filled well, and it is needless to add were the medium of the heaviest of betting.

"The tale has doubtless lost nothing in the telling, and sums are wont to be magnified by tradition, but the thousands landed at seven to four on Historian (who lost several lengths start) in a Handicap Plate, half a mile, in the year 1865 did, we believe, really amount to what was complacently spoken of by those Titans of speculation as ' a very nice little stake.'

"It was, however, as far back as I 860 that the largest field there recorded turned out for the Amport Stakes of a mile and a half. Twenty-one runners, comprising a goodly number of previous (or subsequent) winners, would nowadays be esteemed no unworthy array to face the starter for the Cesarewitch.

"The failing health of John Day, most generous, genial and hospitable of trainers, and the death or retirement of many of his chief supporters, soon dimmed the lustre of the once powerful stable, and 



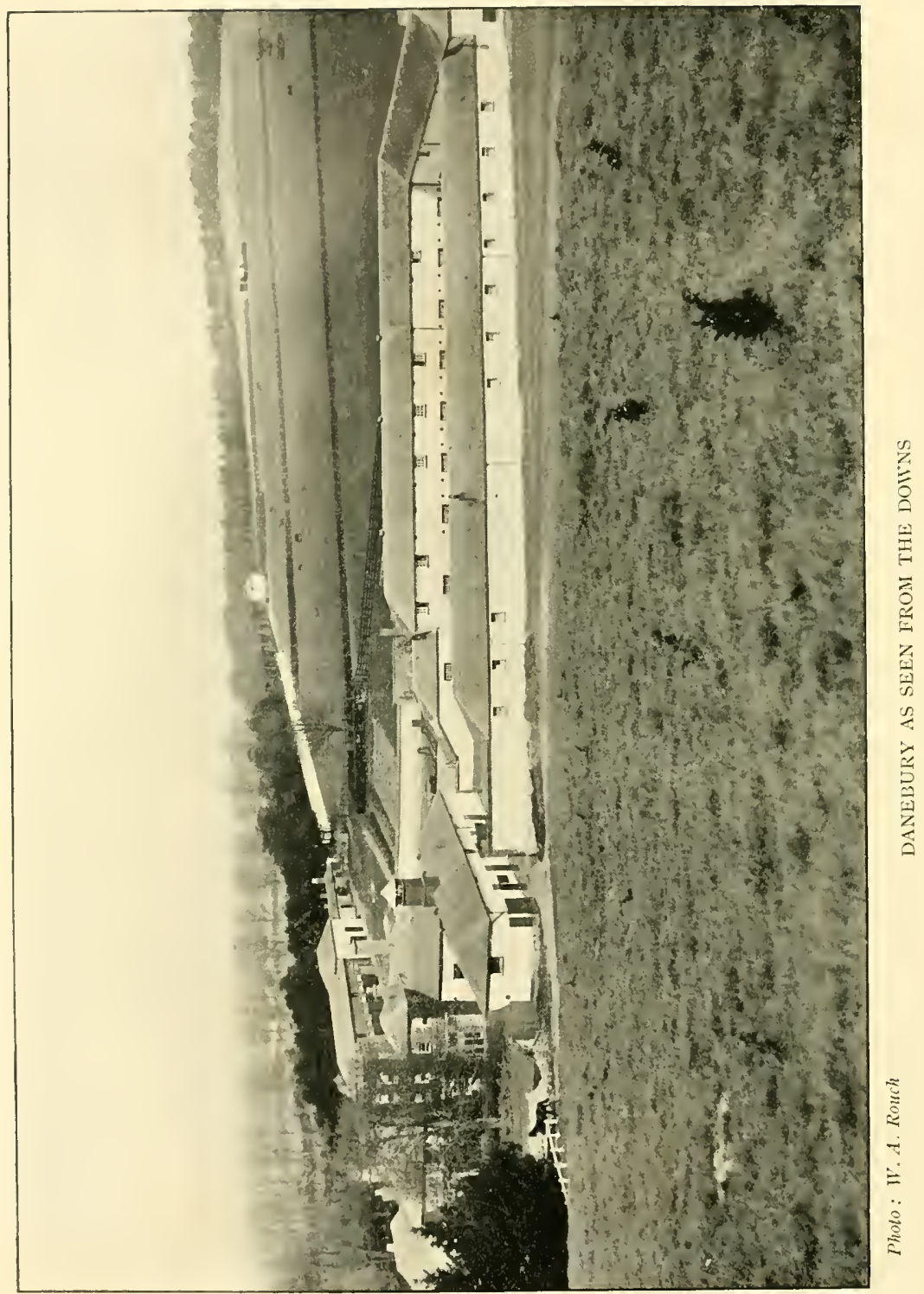


latterly a squadron of cavalry might have been stalled where but a few years ago there was scarcely spare standing-room for a hack.

"So, merged in the fortunes of Danebury, waned the renown of the Stockbridge meeting, till, with the exception of the two events above referred to-the Hurstbourne Stakes and Stockbridge Cup-or when now and again a two-year-old of good report came forth for the Mottesfont, Troy, or Champagne, the races sank to the merest plating level; but, let the racing be good or bad, what man is there who, having once experienced the indefinable charm of Stockbridge, does not long to go there again? For there you can see races as you can nowhere else. Stands there are, one for the use of the general public and one (built by private subscription from a fund started in $\mathrm{I} 866$ by Sir John, then Colonel, Astley), the property of the Bibury Club; but stroll on to the course, and take up your place where you will, either within or without the enclosures, there is so much space, and such is the conformation of the ground, that, from the fall of the flag you shall behold, not, as is usually the case, your neighbour's hat, or the fringe of a lady's parasol, but every change and incident of the contest, to the final struggle out of the treacherous dip to the winningpost. Here, too, by those whom it interests, may be watched every stage of the amateur's progress; for our most famous gentlemen-riders have graduated $2 \mathrm{C}$ 
on a course which the professionals declare taxes their judgment and skill more than any other in England.

"Since the death of John Day in I 883, the establishment and training grounds of Danebury have passed into the hands of his son-in-law, Tom Cannon; a man ' many-counselled' and of much sagacity, under whose management Stockbridge seems likely to renew its youth, and continue to flourish exceedingly, a living proof that 'Palings do not a meeting make, nor iron rails a course.'"

To avoid the somewhat inconvenient journey to the meeting it was the custom of some of its frequenters to take a cottage in the neighbourhood, and if they were fishermen the week's sport often included the capture of some Test trout. Few of the chief supporters of the Turf were absent. William Day, brother of John of whom Lord Suffolk speaks, has given me his account of the Historian race, for he trained the horse. It appears that Sir Frederick Johnstone and his friends had gone badly at the meeting and though it had not been intended that Historian should run he was sent for to act as a retriever. A limitless commission was launched and the wonder is that those who executed it were able to lay as little as 7 to 4 on at the finish. It would be interesting to know the figures which were written down in the books of those who did the business. This occurs to me 
because some time since, looking through an old volume of the Raiing Calendar of about this period with Lord Coventry, I noticed that he had won a minor Plate. I asked him what sort of a horse the humble winner had been and gathered that it was by no means a good one, but that it had been expected to win that particular event. Lord Coventry went on to tell me that he and his partner, Lord Courtenay, afterwards Lord Devon, had sent into the ring to back this animal for as much as the commissioner could get on. I enquired if Lord Coventry remembered what the amount might have been, and he replied that it was something over $f_{4} 6,000$. The horse started at 6 to 4 and won. It cannot be supposed that this was an altogether exceptional event, and one may gather how betting ranged in the sixties when owners thought they had what looked like a good thing.

It will be understood with what anxiety the start of the race in which Historian was running must have been watched, for in a half-mile sprint there is little time to make up for a bad beginning. When the flag fell Historian's head was turned in the wrong direction! How his jockey contrived to get him round and to overtake those who had jumped off, William Day professed himself unable to guess, but Historian got home by a short head.

It will perhaps scarcely be gathered from what Lord Suffolk writes of the Hurstbourne Stakes that this 
was for a period one of the most interesting two-yearold events of the season. Famous horses in Turf history have run for it. The winners include amongst others Friar's Balsam, whose performances are recorded on a former page, Donovan and Riviera; the last named a filly who distinguished herself in a year when several of her age and sex were of exceptional merit. Her career was cut short. While cantering one day on the Limekilns she faltered and fell for no discoverable reason. The going was perfect, and nothing was near her, so that she could not have been struck into. On examination it was ascertained that she had broken her back. A somewhat similar accident happened at Stockbridge in the race for the Cup. A filly called Counterpane belonging to the Prince of Wales after leading past the post fell dead, though I believe in her case heart disease was the cause. I rather think that Lord Suffolk post-dates the death of John Day, that it was prior to I 883 when Tom Cannon took possession of Danebury, where during his reign I was a frequent visitor.

Tom Cannon was the most hospitable of men and the most interesting of hosts to an enthusiast like myself, keen to learn what he could about the horse and how to train him. In the days of which I am writing there were several different gallops on the spacious Downs. The racecourse was little used except for trials. Tom Cannon realised that horses sent to exercise 
on the same ground day after day found it monotonous, and he varied the work accordingly. I think there were more horses in training at Danebury then than in any other stable, the majority of them being Tom Cannon's own property. Hacks were numerous, and on my first visit, having been provided with a charming mount, I made a remark to that effect when I dismounted on our return to breakfast after watching the exercise. "Yes, he won the Cesarewitch," Tom Cannon replied. It was, in fact, Duke of Parma who had carried off the great Handicap for Prince Soltykoff in I 875, and for some years afterwards whenever I rode out of Danebury it was always on the old Cesarewitch winner, on whom also I hunted with the Tedworth hounds. I was indeed the last to sit on his back. One afternoon we cantered over to Garlogs, a property within a short distance of Danebury which Tom Cannon had just acquired. The horse pulled up quite sound, but in the stable next morning it was discovered that he was hopelessly lame and he had to be shot.

Not a few good winners came from Danebury about this period, including Curzon, second to Sir Visto for the Derby of I 895. He was a half-bred gelding, and I fancy it was by reason of his prominence that the conditions of the Derby were altered, confining the Blue Riband to entire horses. Postscript, who won the Metropolitan of I 886 and was confidently expected to 
win the Cesarewitch, was another Danebury bred, as was Reminder, who won the City and Suburban of I895, having been purchased by Sir George Chetwynd, and Humewood, winner of the Cesarewitch of 1887 , sold shortly before the race to Lord Rodney. But Danebury-bred winners were too numerous to mention. Tom Cannon was not on good terms with his tenant Chandler, the trainer, who occupied the Houghton Downs Farm, the reason being that Chandler was in the habit of taking out his gun without permission from his landlord; but Amphion was in the Houghton Downs stables, Tom Cannon declared that he must have a ride on this charming chestnut, and for a time the quarrel was patched up.

The events with gentlemen riders were a feature of the Bibury Club Meetings, as indeed to a less extent they continue to be now that the Club has removed to Salisbury. Mr. Arthur Coventry was continually to the fore in Tom Cannon's scarlet and white hoops, other familiar names being those of Mr. George Lampton, Mr. Hugh Owen, Mr. Hedworth Berkeley, Mr. Hanbury, Lord Marcus Beresford, Capt. Robert Sandeman, Mr. Bevill, Capt. " Roddy" Owen. These were all experienced practitioners, but sometimes members of the Club less accustomed to the saddle rashly embarked upon enterprises which they failed to enjoy. One of them started one day on a two mile race, and when the field had gone some 
200 yards, "Oh I do wish this infernal race was over!" was his agonised exclamation. No other course can replace Stockbridge, and pleasant as the Bibury Meeting at Salisbury may be the abandonment of the old home of the Club will always be lamented by those who knew it.

During the tenancy of Mr. William Moore I lost touch with Danebury, though much interested in $\mathrm{Mr}$. George Bulteel's great 'chaser Manifesto who was trained there, but I resumed acquaintance with the place when my friend $\mathrm{Mr}$. Fred Withington came into possession. Among the winners he produced was Major Douglas Pennant's Rubio, whose career was extraordinary. The horse, American bred, had been turned out of training and lent to an innkeeper at Towcester, who ran him in the station omnibus and for a change let him out in a dog-cart. It is recorded that a commercial traveller, innocent of racing knowledge, hearing doubt expressed as to whether Rubio "stayed three miles" scornfully declared that there could be no sort of doubt about it-he had driven the horse thirty miles himself, more than once. I watched the National in company with Mr. Withington from the top of Lord Derby's stand, and surely no trainer was ever more surprised than he when Rubio won easily from Mattie Macgregor, a mare he also trained and regarded as considerably the better of the two. 
Lord Glanely was specially tempted to acquire the estate because of the ideal paddocks. It is said that Lord George Bentinck, one of the famous owners and breeders associated with Danebury, took off his coat one day and helped to spread bone dust on the turf. Close by are the graves of Bay Middleton and Crucifix, whose names are immortal in racing history. Here a number of Lord Glanely's mares are sheltered, others being at his Exning estate near Newmarket.

One thing established beyond question is that what a mare does when in training affords no guide to her prospective value in the paddocks. Some of the best horses in racing history have been the offspring of mares who were practically useless for racing purposes. The dam of Isinglass was picked up by the astute Captain Machell for a mere trifle. We have seen that Doris, the dam of Sunstar-by no means her only winner-ranked as a poor plater, Admiration the dam of Pretty Polly was a poor class hurdler, and it has been shown that Grand Geraldine, the dam of Grand Parade, was of very small account. On the other hand some of the mares who have made great names for themselves as winners have transmitted none of their racing capacity to their offispring. What Lord Glanely's mares did while they were actively employed is therefore of comparatively little importance. The main requisite is winning blood, the strains that 208 
produce winners, though the immediate dam may not have carried on its virtue.

One famous mare at Danebury, great as a racehorse and successful as a dam, is Sceptre, now twenty-three years old, an age beyond which mares have produced winners of high merit. Sceptre was discussed at length in a previous chapter. Of late years it must be admitted that she has not fulfilled the promise which Maid of the Mist seemed to give. Queen Carbine, her daughter by Carbine, born in 1909, did nothing. She was barren to Cicero next year, to Marco the year following, Curia, her daughter by Cicero, flattered to deceive. Grosvenor, Cúria's brother, was a winner, and that in respectable company; but in I9I4 she was barren to Swynford, and Sceptre's Daughter, as her offspring by the same horse of 1915 was called, turned out a failure. In 1916 she was barren to William Rufus, her daughter by Glenesky, Queen Empress, revived no glories, never having run. I think it was rather sentiment and desire to benefit the Red Cross Fund than any hope of breeding winners that induced Lord Glanely to purchase Sceptre.

Another mare at Danebury to whom interest attaches is Sentiment, the daughter of Spearmint and Flair, remarkable for the fact that dam and foal made the highest price that has ever been paid for such a combination, it having cost Mr. F. C. Stern I 5,000 guineas to obtain possession of them. Sentiment on 
her part did little to repay the amount. She showed speed in the two races she ran as a two-year-old, finishing third in both; and in spite of what has been said on the subject it is of course highly desirable that a mare should give evidence of the possession of this attribute. But the only race she won during the two seasons she remained in training was the Coveney Maiden Plate, worth $\oint_{175}$, at one of the Newmarket Extra Meetings in I9I4. She is, however, just the sort of mare from whom it seems reasonable to expect winners of class. That Mr. Stern should have paid what he did for Flair indicates the keenness of the competition she evoked. A daughter of St. Frusquin and Glare, she was full of the winning blood to which reference has just been made. Flair won the One Thousand Guineas. Glare was regarded by her breeder, owner of many good mares in his day, as his bright, particular star.

Elm Twig is another well known animal. Though she only won a single race she ran well on various occasions. She was only out in the New Stakes as a two-year-old; as a three-year-old she was second for the Prince Edward Handicap at Manchester. Lord Wavertree sent her to White Eagle on no fewer than five occasions; twice she was barren to him and once her foal died. It would appear that the horse did not suit her, and there is good reason to hope she may do better with He. Her produce 
in I 921 was a filly by him. Elm Twig is by Orme, her dam Lucky Hit by Carbine out of Dona Fortuna by Donovan, a pedigree which would surely make for stoutness in her offspring. Maid of Sker, White Squall and Pitch Blend have been discussed in previous chapters; these have all won races for their owner. Miss L. Thrush-an effort at humour aiming at the mare's sire, Misselthrush-the dam True Art by Veracity, winner of the Cambridgeshire, out of Sarah Bernhardt by Distin dates from I 905 , has already produced winners, notably Sea Song. Llwyn-yr-Eos bears an unknown name. She is a daughter of Thrush, one of the speediest horses of modern days. Glen Clova, who, as recorded, was one of Lord Glanely's first winners, has become a dam of winners herself. Llwyn-yr-Eos dates from I 9 I 3 , and her prospects must be esteemed good. Another promising young mare, born I9I4, is Desla, by Desmond out of Lady Fowler by Wildfowler, Captain Greer's Leger winner, out of Orxema by Saraband. With the exception of Sentiment and Pitch Blend the above named were sent to $\mathrm{He}$, as was Almere, a daughter of Aldford and Favorita, half sister to the Midshipmate.

Sixteen mares visited Grand Parade last Spring. Acclamation, a daughter of Prince Palatine and Claque, was bred by Captain Lionel Montagu, who tells me that she was all he got out of three subscrip-

$2 \mathrm{D} 2$ 
tions to her sire and three the same season to Sunstar. Breeding is if possible even a greater lottery than racing. She is the dam of a yearling by the Derby winner of I9I9. Bright Folly also went to him, others so mated include Lady Fowler and her daughter Lady Juliet; Bountiful Polly by PolymelusLady Bountiful; Estrella, a daughter of Spearmint and Chère Reine, dam of a brown filly by Grand Parade; Grey Flier, a grey by Friary out of Bird of March, who never ran, but whose son First Flier won the Irish Derby; Jeunesse by Polymelus-Joie de Vivre, the last named dam of Alan Breck and of Prestongrange, who is supposed to be a better animal than his Ascot performance would suggest. Grey Flier has had a bay filly by Grand Parade, a May foal. Continuing the list Katusha (Donovan-Lady M.), dam of a yearling filly went to the horse again; Mentha (Spearmint-Jubilee) has had the same experience as Acclamation, Estrella, Grey Flier, Jeunesse and Katusha, dam of a (May) filly she should have another ; Polly Dimples (Polymelus-Dimples) is in the same case and so is Tingvalla. The names to be added are those of Sentiment, Queen Empress, Welsh Beck (Troutbeck-Welsh Rarebit) and Witch of the Wave (Spearmint-Lady Jess).

To Skyrocket his owner has sent Amoureuse, by St. Amant-Bell Flower, half sister to the speedy Salandra, who after making a name for himself in 


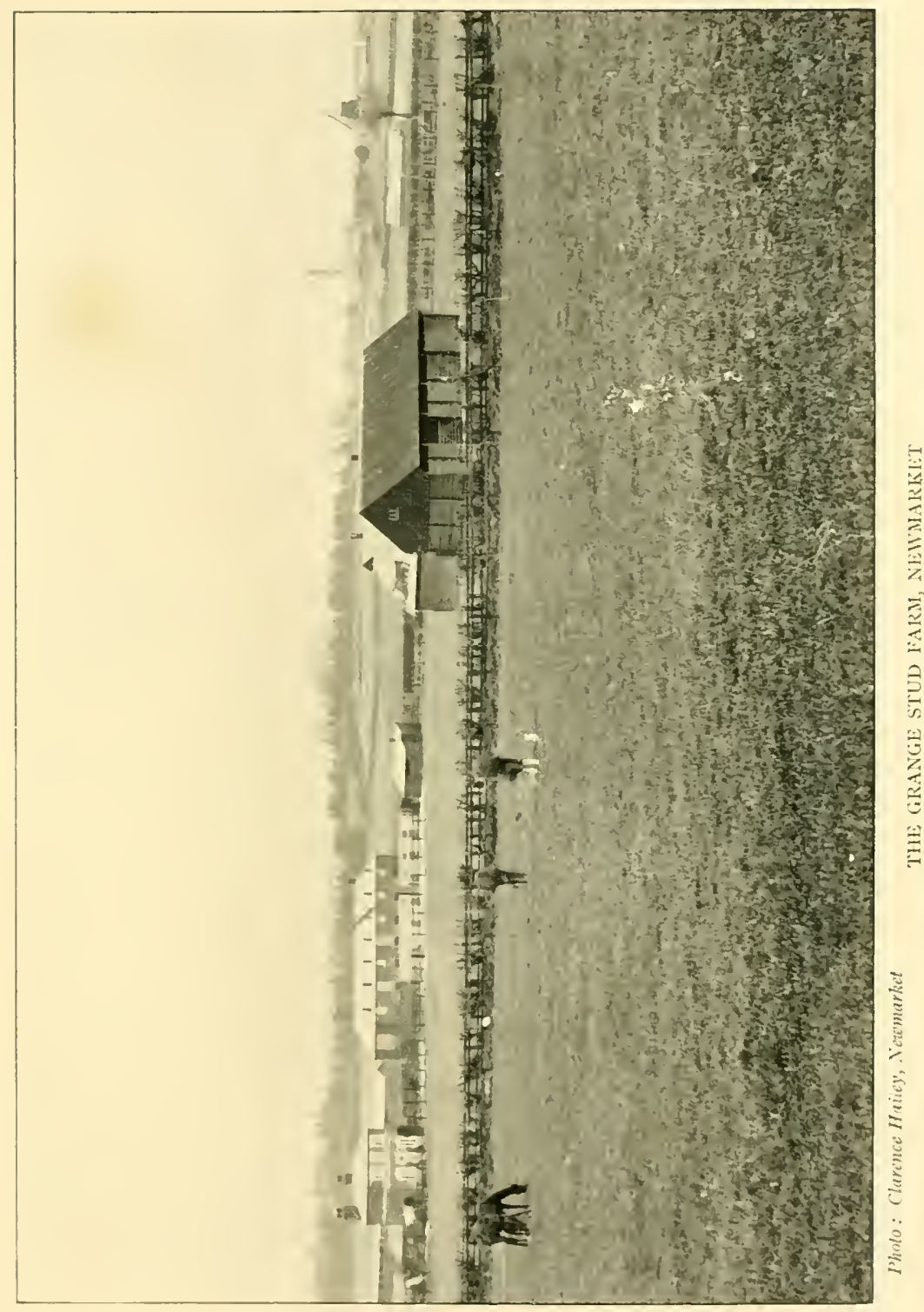



England became a champion in India; Anthracite (Orby-Elephant), dam of a filly by this horse; Kitty Muldoon, of whom mention has been made in the course of the narrative; Lady Mabel (Land LeagueMint Agnes), dam of a Skyrocket filly; Little Thoughts (Flotsam-Little Tinks), dam of a Skyrocket colt; Melton Fuse, dam of the smart Western Hill, whom we have discussed; Pitch Blend; Suffolk Guide, a daughter of the Gull and Melton's Guide, who never ran; and Sweet Louise, a daughter of St. Frusquin and Ardmore-own sister to Arda-dam of a bay colt by the same sire.

A short allowance of three went to Treclare, Placidia by Valens-Red Heart's Pride; Somerset Lassie; and Spearm, a daughter of Spearmint and Romping Peggy, who was never trained. The only mare Lord Glanely sent to any sire except one of his own was Excellent, by William the Third-Excellence. She never ran, produced a bay or brown colt to Grand Parade this year (I92I), and was mated with The Tetrarch.

Lord Glanely's yearlings of the present season consist of six colts and eight fillies. The former are by Argosy-Sweet Louise; Bay d'Or-Sandtoft ; Roi Hérode-Jeunesse; Argosy-Grey Flier ; Quantock-Melton Fuse and Swynford-Amoureuse. The fillies are daughters of Mount William and Estrella; Argosy and Elm Twig; Argosy and Kitty 


\section{A GREAT YEAR}

Muldoon; Argosy and Katusha; Captivation and Welsh Rarebit ; Mount William and Polly Dimples; Quantock and Mentha; White Magic and Miss L. Thrush.

The foals of 192 I number twenty-three, of whom twelve are colts. The sons of Grand Parade, to summarise, are out of Excellent, Acclamation, Jeunesse and Amoureuse; sons of $\mathrm{He}$ are out of White Squall, Maid of Sker, Sandtoft and Queen Empress; there are three Skyrockets out of Little Thoughts, Sweet Louise and Witch of the Wave, together with a Treclare out of Lady Fowler. Six of the eleven fillies are by Grand Parade, their dams Tingvalla, Estrella, Katusha, Polly Dimples, Mentha and First Flier. Daughters of $\mathrm{He}$ are out of Pitch Blend, Elm Twig and Lady Juliet, those of Skyrocket out of Anthracite and Little Mabel. 




\section{POSTSCRIPT}

\section{Westward Ho! and Blue Ensign}

THE book must not be allowed to close without a few words on the subject of two horses to whom special attention has been directed, for one reason, because of the prices that were given for them. In such cases it is not always borne in mind that the money paid at auction does not merely advance evidence of a wealthy man's determination to gain possession of a certain colt. The purchase price represents the value, there or closely thereabouts, in the opinion of more than one presumable authority; for the owner who acquires the lot has headed the offer of the penultimate bidder.

At the Doncaster sales in I9I9 none of the yearlings attracted quite so much admiration as a brown son of Swynford and Blue Tit. It was obvious that there would be keen competition for him, which of course means that he was bound to fetch an extraordinary price, and great curiosity existed to know who would last longest, would stay to the fall of the 
hammer. For I I, 500 guineas Lord Glanely acquired the colt, and presently named him Westward Ho! In any case it is possible that such a big, unfurnished young one might not be ready as a two-year-old, and it was certain that he could not be nearly at his best. The question of endeavouring to train him for his engagements was, however, solved by the development of a thorough pin. The colt was in Fred Darling's stables at Beckhampton where the ailment was effectually treated, and as a three-year-old in May Westward Ho !, if not really fit, was fit enough to be sent to run for the Beacon Maiden Plate at Lingfield. It was seen that he had grown in the right way, and he looked magnificent with the sun on his rich brown coat while being led round in the paddock before the race.

Backers and bookmakers did not at first quite know what to make of him, and even money was offered in the field of twelve, only two of whom had been out that season. Gradually the colt advanced in the market till odds of 7 to 4 were laid on him ; and he won easily if by no more than three parts of a length from Soldier Song and Donna Branca, the latter a daughter of Westward Ho's sire who finished fourth for the Oaks prior to winning the valuable Coronation Stakes at Ascot. Lord Glanely did not entirely forgo a faint hope of the Derby, notwithstanding that the colt was not yet quite ready, that in 


\section{POSTSCRIPT}

fact he wanted not perhaps very far short of a month's work; and he ran in a way which demonstrated that this was the correct view. Epsom was the scene of his last appearance prior to the time of writing; but he has done enough to suggest that a brilliant future is before him, and in course of time he should make an ideal sire.

At Doncaster, twelve months after Lord Glanely became possessed of Westward Ho!, his half brother by The Tetrarch was perhaps the most interesting lot in the catalogue, and it was soon made clear when he entered the ring that he was destined to join the other colt. The price paid for the former was passed before bidders one after another dropped out, and it was not till an additional 3000 guineas had been reached that the opposition were silenced. For I 4,500 guineas Blue Ensign, as he was called, became Lord Glanely's property. A stroke of bad luck befell him. His hock was injured by an accident in his box, though happily the affair did not prove serious. If he never ran he might very likely nevertheless turn out to be a cheap bargain for the stud, but he is in good work (June I92I), is giving every satisfaction, and should win notable races. 






